NBER WORKING PAPER SERIES

\title{
WHEN INVESTOR INCENTIVES AND CONSUMER INTERESTS DIVERGE: PRIVATE EQUITY IN HIGHER EDUCATION
}

\author{
Charlie Eaton \\ Sabrina Howell \\ Constantine Yannelis \\ Working Paper 24976 \\ http://www.nber.org/papers/w24976 \\ NATIONAL BUREAU OF ECONOMIC RESEARCH \\ 1050 Massachusetts Avenue \\ Cambridge, MA 02138 \\ August 2018, Revised April 2019
}

We are grateful to discussants Pierre Azoulay, Michael Ewens, Jonah Rockoff, and Richard Thakor and also for comments from Raji Chakrabarti, Francesca Cornelli, David Deming, Michael Dinerstein, Michael Ewens, Caroline Hoxby, Will Gornall, Arpit Gupta, Justine Hastings, Steve Kaplan, Larry Katz, Theresa Kuchler, Alexander Ljungqvist, Holger Mueller, Thomas Philippon, Larry Schmidt, Antoinette Schoar, Albert Sheen, Doug Staiger, Lesley Turner, Jeff Wurgler, David Yermack and seminar participants at the NBER Labor Studies and Education Summer Institute, MIT Sloan, Harvard Business School, Yale School of Management, Berkeley Haas School of Business, The Federal Reserve Bank of New York, the NBER Entrepreneurship meeting, the FMA Napa Conference, the SFS Cavalcade, and NYU Stern. We are also grateful to Suzanne Chang, Dalya Elmalt and Katerina Nikalexi for superb research assistance. Sabrina Howell thanks the Kauffman foundation for generous financial support, and thanks the Stern Infrastructure Initiative for Preqin data. Constantine Yannelis thanks the Fama Miller Center and the Becker Friedman Institute for generous financial support. The views expressed herein are those of the authors and do not necessarily reflect the views of the National Bureau of Economic Research.

NBER working papers are circulated for discussion and comment purposes. They have not been peer-reviewed or been subject to the review by the NBER Board of Directors that accompanies official NBER publications.

(C) 2018 by Charlie Eaton, Sabrina Howell, and Constantine Yannelis. All rights reserved. Short sections of text, not to exceed two paragraphs, may be quoted without explicit permission provided that full credit, including $\odot$ notice, is given to the source. 
When Investor Incentives and Consumer Interests Diverge: Private Equity in Higher Education Charlie Eaton, Sabrina Howell, and Constantine Yannelis

NBER Working Paper No. 24976

August 2018, Revised April 2019

JEL No. G24,G38,H52,I2,J01

\title{
ABSTRACT
}

This paper studies how private equity buyouts create value in higher education, a sector with opaque product quality and intense government subsidy. With novel data on 88 private equity deals involving 994 schools, we show that buyouts lead to higher tuition and per-student debt. Exploiting loan limit increases, we find that private equity-owned schools better capture government aid. After buyouts, we observe lower education inputs, graduation rates, loan repayment rates, and earnings among graduates. Neither school selection nor student body changes fully explain the results. The results indicate that in a subsidized industry maximizing value may not improve consumer outcomes.

\author{
Charlie Eaton \\ University of California, Merced \\ Department of Sociology \\ 5200 N. Lake Road \\ Merced, CA 95348 \\ ceaton2@ucmerced.edu \\ Sabrina Howell \\ NYU Stern School of Business \\ KMC 9-93 \\ 44 West 4th Street \\ New York, NY 10012 \\ and NBER \\ showell@stern.nyu.edu
}

Constantine Yannelis

University of Chicago

Booth School of Business

5807 South Woodlawn Avenue

Chicago, IL 60637

constantine.yannelis@chicagobooth.edu

A online appendix is available at http://www.nber.org/data-appendix/w24976 


\section{Introduction}

Private equity buyouts are known to increase firm value (Kaplan 1989, Boucly, Sraer, and Thesmar 2011, Davis et al. 2014). ${ }^{1}$ How they create value may differ across industries in ways that have important implications for target firm stakeholders. Prior work has identified at least three mechanisms through which private equity buyouts increase firm value: 1) Reducing financial constraints (Boucly, Sraer, and Thesmar 2011); 2) Improving operational efficiency (Davis, Haltiwanger, Handley, Jarmin, Lerner, and Miranda 2014, Bernstein and Sheen 2016); and 3) Adopting information technology (Agrawal and Tambe 2016). ${ }^{2}$ Shleifer and Summers (1988) identify a fourth potential mechanism in the context of hostile takeovers: the breach of implicit contracts with stakeholders. In competitive industries where incentives are aligned between stakeholders, the first three mechanisms enable private equity buyouts to create value for both consumers and equity holders, as Bernstein and Sheen (2016) and Fracassi, Previtero, and Sheen (2017) find in the case of fast food restaurants and big box retail stores. Conversely, in sectors with intensive government subsidy and opaque product quality, value for equity holders may come at the expense of consumers, as a result of the fourth mechanism.

We study private equity buyouts in post-secondary education, where information frictions combined with government loan guarantees and direct subsidies contribute to incentive misalignment among stakeholders. We examine value creation and its consequences among three stakeholders. Proxies for value creation from the equity holder perspective include enrollment and profits. Proxies for value creation for the government (taxpayers) and for consumers (students) include graduation rates, earnings, loan burdens and repayment rates, and tuition. We show that private equity buyouts positively affect proxies for firm value and find results consistent with the three established mechanisms. We also show that the buyouts lead to greater capture of government aid and deteriorating student outcomes, consistent with implicit contract violation.

\footnotetext{
${ }^{1}$ See also Cao and Lerner (2009), Guo, Hotchkiss, and Song (2011), and Bernstein, Lerner, and Mezzanotti (2017).

${ }^{2}$ Fund managers can increase value though operational changes because buyout contracts give them substantial control rights over the firm. Private equity contracts are complex and state-contingent, usually giving the investor substantial control rights (Lerner and Schoar 2005). For overviews, see Kaplan and Strömberg (2009) and Metrick and Yasuda (2010).
} 
We employ novel data on 88 deals in which private equity firms acquire independent, privatelyowned schools. These deals are associated with 557 school-level ownership changes, of which 218 occur after the deal through acquisitions. Private equity-owned school systems establish an additional 437 new schools. Using regressions with school and year fixed effects as well as a matching estimator, we confirm findings from the existing literature that private equity ownership leads to higher profits; in our data, profits triple after a buyout. Existing literature has also found better management among private equity-owned firms (Muscarella and Vetsuypens 1990, Bloom, Sadun, and Van Reenen 2015, Cornelli and Karakaş 2015, and Cohn, Nestoriak, and Wardlaw 2017). In line with the aforementioned channel, we find that chief executive turnover increases after a buyout by around 36 percent.

The higher revenue that we observe comes partly from a $\$ 1,600$ increase in tuition, which is approximately half average total tuition at community colleges. It also comes from almost 50 percent higher enrollment. Reliance on federal aid increases after private equity buyouts and approaches the 90 percent of revenue threshold that is the statutory limit. Per-student borrowing and per-student federal grants increase by about 12 and 14 percent of their respective means. We exploit a 2007 student loan borrowing limit expansion to test whether private equity-owned schools are more responsive to changes in federal loan guarantees. Relative to other institutions, private equity-owned schools respond to the increase by raising tuition faster than other for-profit schools, which induces higher levels of borrowing. Superior capture of government aid is thus a channel through which high-powered incentives of private equity ownership translate to higher profits. This is a purely rent-seeking phenomenon and is unambiguously not in students' or taxpayers' interest.

We find sharp declines in student graduation rates, loan repayment rates, and labor market earnings after private equity buyouts (the declines are 13, 5.6, and 5.8 percent of their respective means). Enhanced recruiting and reduced instructional quality can reconcile the otherwise puzzling combination of higher enrollment despite higher tuition and deteriorating student outcomes. Private equity-owned schools have twice the share of employees in sales as other for-profits. We show that education inputs, including the ratio of faculty to students, the share of 
spending devoted to instruction, decline after the buyout. Transitions to online education could produce declines in faculty ratios. Online education could both reduce transportation costs for students and enable economies of scale for the school. However, we find a small effect of buyouts on the propensity of a school to become primarily online and no effects on the share of distance students, and the effects on student outcomes are not attenuated when online schools are omitted from the sample.

Private equity buyouts may lead to changed operations that are detrimental to student success. There are two obvious alternatives to this interpretation. One is a selection mechanism, in which private equity firms are skilled at selecting targets on trajectories to the changes we observe. For all outcomes, we show visual event studies among switcher-schools around the buyout year. These reveal discontinuous breaks in outcomes and sharp changes to trends around the buyout year. There are no meaningful observable pre-trends. Private equity firms clearly do not acquire schools at random, but this visual evidence indicates that a selection mechanism is thus unlikely to fully explain the effects.

The second alternative channel is student composition. Students who attend after the buyout may be less prepared than those who attended before. This channel has ambiguous implications for student welfare and depends on school value-added, which we do not directly observe. To hold any composition effects fixed, we use partially treated cohorts. These are students in two-year programs who are already enrolled before a buyout occurs but have at least one year at the now private equity-owned school. For graduation and loan repayment rates, we compare the cohort with partial treatment to the previous one with no treatment. Partially treated cohorts experience more than half the negative effect on graduation rates, and the full effect on repayments rates, that fully treated cohorts experience. This does not reflect the elimination of degree programs after the buyout, a possible short term channel. We cannot rule out that the mechanism in the cohort analysis is different from the primary longer term effect, but the cohort analysis strongly suggests that composition does not explain our main results.

Whether additional students enrolled as a result of post-buyout expansion are better or worse 
off depends in part on their outside option. A large literature finds that the expected labor market returns to for-profit education are lower than the returns to non-selective community college. ${ }^{3}$ If the source of expansion is substitution away from community colleges, the new students are unlikely to be better off. Indeed, we find suggestive evidence that a new private equity-owned school in a commuting zone siphons student enrollment growth from community colleges. Consistent with this finding, Cellini, Darolia, and Turner (2017) show that community colleges and for-profit schools are direct substitutes. Substitution towards a school with lower returns is not as surprising as it may seem. In addition to for-profits using much more sophisticated and aggressive marketing, college students are known to be poor forecasters of their future earnings. ${ }^{4}$

The evidence against composition and selection channels does not allow us to rule out that mechanisms besides reduced quality (evidenced by declines in instructional support) explain the negative effects on student outcomes. However, the results offer substantial evidence consistent with private equity ownership leading to implicit contract violations. An important further piece of evidence is that we find dramatic increases in law enforcement actions after buyouts, most of which stem from accusations of recruiting rule violations, such as quotas for sales staff, and misrepresentations of student loan terms, graduation rates, and student employment outcomes.

Our results shed light on how private equity creates value. This is an especially interesting question in the context of private-to-private transactions, which make up over 90 percent of private equity deal value and 99 percent of volume. ${ }^{5}$ When a private equity investor takes a public firm private, agency conflicts decline as control becomes more tightly bound to ownership (Jensen 1989). The mechanisms may be more nuanced in a private-to-private transaction. Compared to the pre-existing, private owners, private equity owners have higher-powered incentives to maximize firm value because fund managers are compensated through a call option-like share of the profits,

\footnotetext{
${ }^{3}$ See Deming et al. (2012), Liu and Belfield (2014), Cellini and Chaudhary (2014), Cellini and Turner (2016), Deming et al. (2016) and Armona, Chakrabarti, and Lovenheim (2017).

${ }^{4}$ For example, see Arcidiacono et al. (2014, 2016); Stinebrickner and Stinebrickner (2013); Wiswall and Zafar (2014); Hastings et al. (2017). This literature has found that students from low income backgrounds are particularly prone to overestimating the earnings of past graduates in their major and institution, and that students who are overly optimistic about their earnings and academic ability are particularly prone to dropping out.

${ }^{5}$ Based on Pitchbook data between 2010 and 2018; see https://pitchbook.com/news/reports/2018-annual-us-pebreakdown and https://pitchbook.com/news/articles/2017-was-an-down-year-for-take-private-buyouts.
} 
employ substantial amounts of leverage, usually aim to liquidate investments within a short time frame, and do not have existing relationships with target firm stakeholders.

Private equity is often treated as a monolith, either praised for creating value or maligned for supposed "strip and flip" strategies. Together, the existing literature and our results suggest that there is important heterogeneity. When incentives between investors and consumers are aligned, quality improvements should accompany firm value creation (Hart, Shleifer, and Vishny 1997). In contrast, for-profit colleges feature severe information frictions and misaligned incentives. There is low price elasticity of demand, in part because tuition is not salient; students often enroll with zero up-front costs. Education quality is extremely opaque, allowing for reducing instructional resources while pursuing misleading marketing and recruiting strategies. The for-profit target population is vulnerable to these approaches because it is extremely socioeconomically disadvantaged (Deming, Goldin, and Katz 2012). While dropouts may increase when instructional resources decline, rolling admissions enable rapid enrollment of new students. The required recruiting expenditures, especially with new sales technology adoption, may be lower than the cost of retaining existing students. ${ }^{6}$ The sector also features intensive government subsidy, separating revenue from the consumer. In particular, the expansion of federal student loan programs since the early 1990s created opportunities to increase firm value through implicit contract violations.

As a new owner, the private equity investor may be well-positioned to take advantage of these opportunities for value creation. In order to establish the school, previous owners may have had to commit to implicit contracts with stakeholders; in exchange for government revenue, they would provide a valuable education. Their inability or unwillingness to take advantage of new opportunities is related to the reason why in settings such as healthcare and education, where consumers depend on implicit contracts with the firm, many service providers are nonprofit (Hansmann 1980). Glaeser and Shleifer (2001) discuss how in such settings weaker incentives to maximize profits or increase value for investors can make nonprofit status optimal. This

\footnotetext{
${ }^{6}$ Reducing expenditures on instruction is a well-established cause of lower graduation rates (Bound and Turner 2007, Webber and Ehrenberg 2010).
} 
mechanism requires consumers to rationally choose nonprofit firms over for-profit ones. It may be infeasible for consumers to make this choice when subsidy separates revenue from the consumer and quality is hard to observe. In our context, it seems likely that improved subsidy design could better align incentives. This might be one avenue towards addressing the growth in federally guaranteed student debt - which increased from $\$ 241$ billion in 2003 to $\$ 1.6$ trillion in 2019 - and possible accompanying adverse effects, including high levels of default and reduced entrepreneurship. ${ }^{7}$

Our paper contributes to the literature on private equity and the real effects of acquisitions, including Brown, Gredil, and Kaplan (2013), Ewens, Rhodes-Kropf, and Strebulaev (2016), and Ma, Ouimet, and Simintzi (2018). In addition to Bernstein and Sheen (2016), two papers offer insights related to ours. Matsa (2011) shows that highly levered supermarket firms, which sometimes become highly levered through private equity buyouts, experience higher inventory stock-outs. Ljungqvist, Persson, and Tag (2016) study the misalignment between private and social incentives in private equity-backed stock delistings. Furthermore, our findings may be relevant to other sectors with similar characteristics that also receive large amounts of private equity investment, such as healthcare, infrastructure, and defense. ${ }^{8}$

\section{Data and Descriptive Statistics}

This section first describes the for-profit higher eduction industry, and explains why it may feature incentive misalignment (Section 2.1). We both describe private equity's role in the industry and also introduce our private equity deal data in Section 2.2. We summarize the data from the Department of Education on schools and students in Section 2.3.

\footnotetext{
${ }^{7}$ See Looney and Yannelis (2015), Bleemer et al. (2017), Krishnan and Wang (2017) and Mueller and Yannelis (2019).

${ }^{8}$ See Appendix Figure B1. The healthcare economics literature has examined how incentives and the ownership of healthcare providers affects the price and quality of care, though there has been no study of private equity. While providers do appear to respond to incentives, there are mixed results regarding ownership (Dafny et al. (2016), Duggan (2000), Clemens and Gottlieb (2014), Adelino, Lewellen, and Sundaram (2015), Sloan et al. (2001), Hackmann and Pohl (2018)).
} 


\subsection{Institutional Context}

For-profit schools ("for-profits") have existed in the U.S since the early 1900s, but enrollment grew substantially in recent decades (left graph of Figure 1). As of 2016, about 1.2 million students were enrolled at for-profit schools. In 2011, the last year for which two-year default rates are available, for-profits accounted for about 40 percent of student loan defaults. For-profits attract more socioeconomically disadvantaged students than community colleges, which are the closest comparison (Deming, Goldin, and Katz 2012, Looney and Yannelis 2015).

There are well-known information frictions in post-secondary higher education. An absence of accessible information, the difficulty of assessing returns to education, and long lags between enrollment and job placement impede the transmission of product quality to future sales (Bettinger et al. 2012, Stinebrickner and Stinebrickner 2013, Wiswall and Zafar 2014). Students are poorly informed about their own ability, their school's quality, and expected earnings from the program they have chosen before starting post-secondary school (Stinebrickner and Stinebrickner 2012, Arcidiacono et al. 2014, Wiswall and Zafar 2014, and Arcidiacono et al. 2016). For example, Hastings et al. (2017) find that students who apply to low-earning college degree programs overestimate earnings of recent graduates by approximately 100 percent. The school faces a tradeoff between the potential costs to its reputation of failing to educate students, and the direct costs of providing that education. A significant body of work suggests that the former may be low, because students are not well-informed about which programs are optimal for them, programs are difficult to compare to each other, and prospective students rarely have visibility into previous cohorts' outcomes (Lang and Weinstein 2013).

For-profits devote far more resources to recruiting than other types of schools, which compounds these information frictions. Due to federal loan and grant programs, salespeople can market zero upfront costs to low-income students, despite higher average tuition among for-profits than alternatives. Figure 2 shows the share of school employees in sales (left graph)

and non-instructional activities (right graph), by school type and ownership between 2012 and 2015 , the years during which data is available for this variable. While public and non-profit 
schools have less than one percent of employees in sales, private equity-owned schools have over seven percent of their employees in this area. Other non-private equity-owned for-profits have four percent. Government investigations have found evidence of deceptive marketing practices among for-profits (Senate 2012).

About 90 percent of revenue at for-profits comes from public sources (CFBP 2012, Kelchen 2017). They are incentivized to target low-income students, who qualify to pay tuition primarily with federal grants and loans and so need not be billed regularly. Tuition is the most important determinant of the amount of federal aid a student may receive, which incentivizes for-profits to increase tuition above cost (Cellini and Goldin 2014). Federal revenue arrives when the student begins school and is largely disconnected from graduation rates and labor market outcomes. The taxpayer bears the cost of student defaults. ${ }^{9}$ Thus, government aid and loan guarantees create a potential misalignment of incentives between for-profit school owners and consumers (see Appendix Sections A.1-A.3 for further discussion). From a profit maximization perspective, government loan guarantees make the school indifferent to whether a student defaults.

Most of our school characteristic and student outcome data come from the U.S. Department of Education Integrated Post-secondary Education Data System (IPEDS). All schools that are Title IV eligible must report to IPEDS, and this includes the vast majority of the higher education sector, including at least 73 percent of for-profits (Cellini and Goldin 2014) Most variables are reported at the school level according to a unique "UnitID" that remains constant over time and across ownership changes. There are no UnitID mergers in our sample. We create a unique identifier, "SystemID", to represent the parent institution, including parent companies of for-profit college chains. This is important because for-profit college companies often operate multiple schools. ${ }^{10}$

\footnotetext{
${ }^{9}$ Legislation proposed in the U.S. Congress in November, 2017 would require schools to repay a portion of defaulted student loans. A Wall Street Journal article noted that "This so called skin-in-the-game proposal has been long fought by the powerful higher education lobby." See https://www.wsj.com/articles/house-gop-to-proposesweeping-changes-to-higher-education-1511956800.

${ }^{10}$ The data used for analysis are comprised of an unbalanced panel. Exit, however, is much less common among private equity owned schools. New schools enter the data set when they become Title IV eligible. Of the 994 schools that were ever Title IV eligible and under private equity ownership since 1987, 194 leave the dataset due to closure or cessation of Title IV reporting prior to the last year for which data is available. Another 291 schools owned by private equity are excluded from our analysis in years following changes in their parent company to publicly traded ownership. Among the 7,034 for-profit schools that were ever Title IV eligible but never under private equity ownership, 4,410
} 


\subsection{Private Equity in Higher Education}

Private equity buyouts of publicly traded firms in the 1980s were thought align managers with investors interests in short-term profit maximization (Jensen 1989). In recent decades, however, managers of publicly traded firms have to some degree deterred leveraged buyouts through increased shareholder value creation, both through changes to governance and increased profitability (Holmstrom and Kaplan 2001, Kaplan and Strömberg 2009). Parallel to this shift, private equity investors increasingly turned to investments in smaller, privately-held companies. Acquisitions of privately held firms made up a majority of all U.S. buyouts between 1980 and 2005 and constitute all but two of the buyouts in the for-profit college sector in the years for which we have complete data (Davis et al. 2014).

Private equity buyouts can affect target firm operations and finances. Operationally, Bloom et al. (2015) find that private equity owned firms have superior management than other privately owned firms. Davis et al. (2014) show that private equity owned manufacturing firms expand productive plants and shutter underperforming ones. Bernstein and Sheen (2016) demonstrate that restaurant worker training and incentive alignment improve after private equity buyouts. Fracassi, Previtero, and Sheen (2017) also find that consumers benefit from private equity buyouts of chain retail stores. Financially, private equity buyouts are typically accomplished using debt that is collateralized by target firm assets (Metrick and Yasuda 2010). This paper focuses on student outcomes and does not address firm capital structure.

To collect higher education private equity deal data, we researched the parent ownership history of every for-profit college in the U.S. from 1987 through 2016 that was eligible for federal aid (termed "Title IV eligible"). We used a variety of sources, which was necessary for two reasons. First, no single existing source contains comprehensive data on buyouts of for-profit colleges. Second, commercial databases do not track the individual schools that each portfolio firm operates. We began with a comprehensive list from IPEDS for all 7,034 Title IV schools that ever reported for-profit ownership. We then manually researched the ownership history of each close or cease Title IV reporting prior to the last year for which data is available. 
school and its parent company. One way that we identified parent firm ownership was by matching schools to firms based on the Employer ID Number reported in IPEDS. Two sources were especially useful. First, schools have been required since 2008 to describe their ownership history in online course catalogues, which we obtained via Internet archives. ${ }^{11}$ Second, we used unpublished documents from the 2012 Senate HELP Committee report of for-profit colleges and $10-\mathrm{K}$ statements for publicly traded firms. The next step was to identify private equity buyouts of parent firms by searching the ThomsonOne and Preqin databases.

We identified 88 private equity buyouts of for-profit college companies before 2016. None of the deals we use in analysis are secondary deals. In some cases, the private equity owner exits by selling to another private equity firm. We do not examine these deals; as far as our data are concerned, the school remains private equity owned. Of the firms involved in the deals, 35 percent have an education specialty, and the average number of education deals is 2.1 (the median is zero). Median fund returns are roughly similar to industry benchmarks. ${ }^{12}$ Figure 1 shows the private equity-owned share of total enrollment and defaults over time. Defaults are measured at least three years after graduation, so we terminate both plots in 2011 . We include formerly private equity-owned publicly traded schools. Private equity-owned schools account for approximately 35 percent of total for-profit enrollment in our data on the near-universe of for-profits. Most of the increase in the for-profit share of student loan defaults since 2000 has been among private equity-owned schools.

Private equity investments in higher education have taken two forms. One is the purchase of independent (small, private) colleges, usually with consolidation intent. An example that illustrates the broader pattern we find in the data is TA Associates' buyout of Florida Career College for $\$ 53$ million in 2004. At the time, Florida Career College had four campuses and 2,500 students. After adding three additional campuses and expanding enrollment to 4,000 students, TA Associates sold its stake in 2007 for \$192 million, almost quadrupling its investment. Later in 2007, federal investigators found employees producing fraudulent high

\footnotetext{
${ }^{11}$ We provide an example of these course catalogs in Appendix E.

${ }^{12}$ Based on data from Preqin and Mitch Leventhal. 62 out of a total of 118 firms match to Preqin.
} 
school diplomas for applicants and encouraging students to lie about their high school status. The second type of deal is the buyout of an existing chain institution; the biggest have taken public companies private. For example, in $2007 \mathrm{KKR}$ and SAC Capital took Laureate Education private for $\$ 3.8$ billion. Eaton et al. (2016) provide further evidence regarding publicly traded and privately owned schools. Other examples include Goldman Sachs taking Education Management Corp (EDMC) private in 2006 for $\$ 3.4$ billion, and various investors, including Vistria Group, taking Apollo Education Group (University of Phoenix) private in 2017 for \$1.1 billion. Appendix Section A.4 describes the role of private equity in for-profit higher education in detail.

At the firm level, we track the 88 buyouts as a SystemID-level changes in ownership. ${ }^{13}$ It is common for the company acquired in a buyout to own multiple schools. After the buyout, this parent company often purchases or establishes additional schools. The 88 buyouts involved changes in ownership for 339 schools. We observe 136 acquisitions of other for-profit companies by private equity owned firms after a buyout, which involved 218 subsequent changes in ownership. The bar graphs in Appendix Figure B2 Panel A plot the 88 buyouts and 557 school-level ownership changes over time. They show that these events are not concentrated in a few years. The histograms in Appendix Figure B2 Panel B contain the number of colleges per buyout and per acquisition. They illustrate a range in the number of colleges involved per buyout; most involve just one school, and the maximum is 35 . In addition to the 557 college level ownership changes, firms under private equity ownership established 437 additional schools. This gives us 994 schools, or UnitIDs, that ever come under private equity ownership. ${ }^{14}$

\footnotetext{
${ }^{13}$ Nearly 80 percent of the deals are known buyouts, while the other 20 percent may be minority stake purchases. For simplicity, we use the term "buyout" in the remainder of the paper.

${ }^{14}$ Some variables are reported at the OPEID level, which in some cases aggregates UnitIDs. There are a total of 374 switcher OPEIDs. This is smaller because OPEIDs sometimes encompass multiple UnitIDs and the data for which we use OPEIDs (repayment rates and earnings) are available for fewer years.
} 


\subsection{School Characteristics and Student Outcomes}

Table 1 summarizes the variables we use in our analysis. ${ }^{15}$ These descriptive statistics indicate that other for-profits are in some ways more similar to community colleges than to private equityowned schools, suggesting that private equity-owned schools may drive many of the characteristics generally associated with for-profits in, for example, Deming, Goldin, and Katz (2012), Cellini and Goldin (2014), Cellini and Turner (2016), and Deming, Yuchtman, Abulafi, Goldin, and Katz (2016). The graduation rate (fraction of students who graduate within 150 percent of normal time) averages 48 percent for private equity-owned schools, compared to 55 percent at other for-profits. We do not report IPEDS data on community college graduation rates because they are neither accurate nor comparable. The average loan per borrower among full-time first year students is $\$ 8,124$ at private equity-owned schools, compared to $\$ 6,700$ for other for-profits and $\$ 4,008$ at community colleges.

There are two measures of loan repayment. The first is the two-year cohort default rate (CDR), which is default rates two years after exit-year for exiting cohorts. Students exit by either graduating or dropping out. We use this in Figure 1 because it has the longest time series. It is, however, known to be subject to manipulation through the use of allowable non-repayment options like deferments and forbearances (ICAS ICAS). Comparisons between for-profits and other types of colleges should therefore be made with caution. We use the CDR time series to analyze potential bunching of default rates close to regulatory limits. The second measure is the share of students in repayment. This is the fraction of borrowers from a school who have not defaulted and have repaid at least $\$ 1$ of their initial balance three years after leaving school (by graduating or dropping out). Repayment rates are more sensitive than default rates, and capture failure to repay through legal channels such as deferment or income-driven repayment options. The repayment rate averages 34 percent among private equity-owned schools, 41 percent at other

\footnotetext{
${ }^{15}$ For comprehensive descriptions, sources, and years available for all variables used in analysis, see Appendix B Table 1. Data are presented at the school (UnitID level). The data span 1987 through 2016, but some variables are not available until the early 1990s. A year corresponds to the spring term of the academic year, which begins on August 1 and ends July 30. For example, observations for the 2008-2009 academic year are identified as 2009.
} 
for-profits, and 46 percent at community colleges.

Private equity-owned schools are larger, with mean enrollment of 747 students, compared to 387 at other for-profits. Per full-time equivalent student, tuition revenue averages $\$ 17,521$ at private equity-owned schools relative to $\$ 14,211, \$ 3,673$, and $\$ 10,996$ at non-private equity-owned for-profits, community colleges, and nonprofit/state schools, respectively. Community colleges and other for-profits respectively have 4.4 and 4.5 full-time faculty per 100 full-time equivalent students, while private equity-owned schools have 3.6. The share of students with federal grant aid and per-student Pell Grant revenue indicate the degree to which the student body is low-income. They are similar at private equity-owned schools and other for-profits, while they are much lower at community colleges. We also compiled statistics on degrees and major types, though these are not reported for brevity. The most common degree type at a private equity target school (in the year before acquisition) is a 1-year Communications degree (18 percent of degrees awarded). Our online time-varying indicator variable follows Deming et al. (2012). ${ }^{16} \mathrm{We}$ observe 126 school switches from not-online to online.

We observe average and median earnings using data from the NSLDS College Scorecard database. The source is a link between students and salaried (W-2) and self-employed (Schedule SE) earnings data from Department of the Treasury tax records. Wage outcomes cover individuals who (a) borrowed from the federal government and (b) were employees in the Social Security system or were self-employed and filed a tax return. Average and median wages are therefore likely higher than if graduates who are unemployed or not in the labor force were included. Earnings are measured six years after cohort exit at the OPEID level for the 1998, 2000, 2002, 2004, 2006 and 2007 cohorts. Average earnings for graduates of private equity-owned schools are $\$ 33,523$ (in 2015 dollars). Earnings for graduates of community colleges are slightly higher, while they are slightly lower for graduates of other for-profits.

We also use data on law enforcement actions. We observe 125 instances of a state or federal

\footnotetext{
${ }^{16}$ The method relies on the fact that a school either has "online" in its name, or has no state constituting more than one-third of freshman enrollment. For-profits usually draw primarily from the surrounding area.
} 
agency initiating an investigation. ${ }^{17}$ Most allegations relate to misrepresentation and false claims. For example, there are 28 cases of job placement statistic misrepresentation, 23 of credentials or accreditation misrepresentation, and 31 of other types of false claims. Violations of sales and recruiting regulations and fraud also feature prominently (44 allegations). We use a school-year level indicator variable for the school experiencing its first law enforcement action. These are not concentrated in a few school systems, nor do any particular private equity firms or private equity firm types have disproportionate actions. The exception is the Fortis system, in which 13 unique schools experienced first-time actions. Although private equity-owned school-years comprise just 4 percent of all school-years in our data, they are 58 percent of the first-time actions.

\section{Estimation Strategies}

We use three primary empirical approaches to assess how private equity ownership affects school and student outcomes: visual event studies, within-school regressions, and a matching estimator. In this section, we describe each in turn. While none of the three have the causal rigor of an experiment, they are quite different approaches from an econometric perspective, so when they all yield results with a similar economic interpretation, they provide powerful evidence of an effect.

The empirical approach is to plot outcome variable means around the year of the buyout, for schools that are acquired by private equity groups. This exercise tests for pre-trends, which sheds light on whether a selection mechanism most likely explains our results. It also demonstrates any raw effect within switcher-schools. We restrict the sample to schools that existed in the year prior to the private equity buyout, so that there is a change of ownership, and do not include schools established by the private equity-owned school systems after the buyouts. After this restriction, there are small variations in sample size across years as schools enter and exit. A school that is not present in a given year for a given variable is recorded as missing.

The second empirical approach is a within-school regression, using variants of the following

\footnotetext{
${ }^{17}$ These are described in Appendix B Table 2. We collected data primarily from Republic Report. https://www.republicreport.org/2014/law-enforcement-for-profit-colleges/ .
} 
specification:

$$
Y_{i t}=\alpha_{i}+\alpha_{t}+\beta_{1} P E_{i t}+\gamma \mathbf{X}_{i t}+\varepsilon_{i t} .
$$

$P E_{i t}$ takes a value of one if the school is private equity-owned in year $t$. We include school fixed effects $\left(\alpha_{i}\right)$ and year fixed effects $\left(\alpha_{t}\right)$, which respectively absorb school and time invariant factors. $\mathbf{X}_{i t}$ is a vector of controls comprising fixed effects for the highest degree that the school offers, whether the school is selective, and whether it is publicly traded (formerly private equity-owned schools are not identified as private equity-owned after they IPO). The sample consists of all institutions in our data. We include non-profits because private equity firms have occasionally purchased non-profits and transformed them into for-profits, though the results are robust to excluding these instances. For each outcome variable we present a second model with additional controls for the demographic composition of the student body. These include family income (Pell grants per student in 2015 dollars) and the shares of students who are black, white, and Hispanic. We two-way cluster standard errors by parent company (SystemID) and year in all specifications. This captures potential correlation across schools within the largest deals. Our results are not sensitive to alternative clustering approaches. Our main specification uses all years of available data, but all our results are robust to excluding pre-2000 data, as there may be concern that it is lower quality. The main results are also robust to restricting to switcher schools and collapsing the years on either side of the buyout into single averages, as suggested in Bertrand, Duflo, and Mullainathan (2004).

Our third approach is a matching estimator. To identify appropriate matching variables, we examine buyout predictors. For this exercise, the sample is restricted to other for-profits. Further, among the target schools, the sample is restricted to the year before the buyout. In a logit model with year fixed effects, we tested a wide variety of observables at the school and commuting zone (proxy for the local labor market) levels. Variables with predictive power are shown in Table 2. Private equity firms target schools in areas with more community colleges and a larger number of total enrolled students, but a smaller number of existing for-profits. This suggests they are identifying areas with large target populations but few competitors. They target schools that have 
lower recent profit growth but higher profits than the average for-profit school. They also target schools with more students, a higher share of students who are white, and that have lower loan repayment rates. No other variables consistently predict being a target. These include education inputs, enrollment growth at the school and commuting zone level, the proximity of revenue to the 90 percent threshold that is the legal maximum, and other student outcomes.

We deploy the variables with predictive power in a nearest-neighbor matching (NNM) estimator. $^{18}$ Unlike propensity score matching, which uses the logit estimated probability of treatment, NNM flexibly (i.e., with no functional form assumption) uses the distance between covariate patterns to define the "closest" control for a given treated observation. The flexibility requires more data, and the data required grows with each additional matched covariate. Therefore, we match only on the variables that have some predictive power (omitting the outcome variable if it is one of the matching covariates) and adjust for bias in matching on multiple continuous covariates. For each private equity-owned school, we match target schools in the pre-buyout year to other for-profits. We assess outcomes two years after the buyout in the matched sample. Considering outcomes two years after the buyout serves as a robustness test for the main OLS approach, which uses all years after the buyout. It ensures that the effects immediately follow the buyout and are not an artifact of something that occurs in later years. Together with the differences in estimating models, this means that the NNM estimates may not always be close in magnitude to the OLS estimates. Appendix Table B3 shows that the imbalance decreases dramatically after the NNM procedure.

\footnotetext{
${ }^{18}$ The variables used are number of community colleges in the commuting zone, number of pre-existing for-profits in the commuting zone besides the target, one-year profit growth, log profits, the log number of FTE students, the 3 -year loan repayment rate, and the share of students who are white. In the final specification 5 of Table 2, where all variables are used, the sample size declines and some variables lose significance. We nonetheless match on these, as they appear to have some predictive power.
} 


\section{Capturing government aid}

This section provides strong evidence that private equity ownership leads to better capture of government aid, which is a mechanism of value creation that is clearly not in the interest of taxpayers. We first establish the greater reliance of private equity-owned schools on federal aid (Section 4.1). We present a test with causal interpretation using loan limit increases in Section 4.2 .

\subsection{Reliance on government aid}

Table 3 contains financial outcomes. Columns 1-2 show that tuition per student increases by over $\$ 1,600$, relative to a mean across all schools of $\$ 9,528$ (note tuition at community colleges averages just $\$ 3,673$ ). ${ }^{19}$ The effect increases in the matching estimator, to $\$ 2,107$ (column 3). The visual event study in Figure 3 Panel A shows a striking increase immediately after the buyout. Average loans per borrower increase by about $\$ 580$ (in 2015 dollars), or about 12 percent of the mean across all schools of $\$ 5,147$ (columns 4-5). The matching model yields a larger effect of $\$ 641$ (column 6). There is an immediate large increase in borrowing in the visual analysis, in Figure 3 Panel B. Note that less than 10 percent of loans at private equity-owned schools in our data are non-federal, and some of these come from state government. By comparison, 24 percent of loans are non-federal at non-profit schools. We also observe large increases in non-Pell federal grants per student (Table 3 Panel 2 columns 1-3), of about $\$ 800$. Finally, Panel 2 columns 4-5 show that profits increase after a buyout by 77 percent, an effect that increases in the matching model. Appendix Figures B3 and B4 show visual event studies for federal grants, revenues, expenditures, and profits.

To be eligible for federal aid, a school may not receive more than 90 percent of its revenue from Title IV programs. Appendix Figure B5 shows the share of school revenue from Title IV sources, such as federal student loans and grants, before and after a buyout. Before the buyout, target schools receive 60-70 percent of their revenue from Title IV programs. This fraction

\footnotetext{
${ }^{19}$ Note that tuition and loan amounts are not directly comparable, as loans are measured for full-time first-year students while tuition is measured across all students on a full-time equivalent basis.
} 
increases to nearly 80 percent six years after a buyout. The variance of the fraction of revenue from Title IV programs also decreases markedly. Private equity-owned schools' fraction of revenue from these programs is tightly clustered just below the statutory cutoffs for aid eligibility, suggesting management that more consistently targets the threshold. Note that the fraction of revenue coming from Title IV programs is a lower bound on the total fraction of revenue coming from all government sources, as there exist many non-Title IV loan, grant and subsidy programs.

\subsection{The Effect of the 2007 Loan Limit Increase}

A regulatory change in 2007 increased student loan borrowing limits. Specifically, Congress raised the Stafford loan limits for all types of students for the first time since $1993 .^{20}$ This created growth options for for-profit schools. We examine whether schools already under private equity ownership were more responsive to this opportunity, and increased tuition and borrowing faster than their counterparts. We employ a standard difference-in-difference framework. Our main coefficient of interest captures the differential effect of private equity ownership on outcomes of interest, relative to other schools before and after the loan limit increase. We compare private equity owned schools to all schools and to other for-profit schools using the difference-in-differences specification in Equation 2.

$$
L_{i t}=\alpha_{i}+\alpha_{t}+\beta P E_{i} * \text { Post } 2007+\gamma X_{i t}+\varepsilon_{i t}
$$

The term $L_{i t}$ denotes average borrowing or headline tuition in school $i$ in year $t$. The coefficient of interest is $\beta$, which captures the increase in average borrowing at private equity-owned institutions relative to other institutions after the limit increase. If private equity-owned institutions are better

\footnotetext{
${ }^{20}$ The increase occurred in two stages, with roughly one-third of the increase affecting the 2007-08 academic year, and the rest beginning with the 2008-09 academic year. There are two types of caps; for annual borrowing and for total borrowing over the course of the degree. One limit increase took effect in 2007 and another took effect in 2008. The 2006 Higher Education Reauthorization Act (HERA) HERA took effect in 2007. It increased annual Stafford loan limits for freshmen, sophomores and graduate students, but did not increase aggregate per-student limits. The Ensuring Continued Access to Student Loans Act of 2008 increased annual and aggregate unsubsidized Stafford loan limits for undergrads. Note that these loans are non-dischargeable in bankruptcy. At the time of the legislation the rate was 6.8 percent for unsubsidized Stafford loans, and 3.4 percent for the smaller unsubsidized loans. GAO (2014) found no effect on tuition or loans, in part because the recession had a strong negative effect on private student lending, while Lucca et al. (2016) argue that the loan limits led to increases in tuition, which is consistent with the "Bennett hypothesis" that schools raise tuition to capture federal loans and grants.
} 
at capturing aid, we would expect average loan amounts to rise at a faster rate relative to other institutions, and the coefficients $\beta$ should be positive and significant. We include school and year fixed effects $\left(\alpha_{i}\right.$ and $\left.\alpha_{t}\right)$ to capture trends such as tuition inflation and school-specific factors, as well as school controls $X_{i t}$ as in Equation 1. Standard errors are clustered at the SystemID level to address potential serial correlation. The year 2007 is excluded, as it is somewhat ambiguous whether treatment occurs in 2007 or 2008 (the results are not sensitive to including 2007).

The main identifying assumption of the analysis is that, in the absence of the limit increases, private equity-owned schools and other for-profits would have had similar borrowing trends. This implies parallel trends before 2007. Appendix Figure B6 restricts the treatment group to institutions that were private equity-owned prior to 2007. Before the 2007 limit increase, the trends are parallel, but afterward the two series diverge, with a larger increase in average borrowing among private equity-owned schools. Table 4 presents estimates of Equation 2. Consistent with the graphical evidence, the results indicate that following the loan limit increases, average borrowing increased by at least $\$ 800$ at private equity-owned institutions relative to other schools, or around 10 percent of the mean (Panel 1). Columns 1-3 include all schools, while columns 3-6 include only for-profit schools. Reflecting increases in borrowing across all schools, the post-2007 indicator is positive. The coefficient on being private equity-owned is also positive, as borrowing was higher at private equity-owned schools before the reform.

To further establish parallel trends and explore the timing of the effects, we run the following specification, interacting the private equity-ownership treatment with indicators for each year.

$$
L_{i t}=\alpha_{i}+\alpha_{t}+\sum_{j=2002}^{2012} \beta_{j} P E_{i} * 1[\text { Year }=j]+\gamma X_{i t}+\varepsilon_{i t}
$$

We again restrict $P E_{i}$ to schools that were acquired by a private equity group before 2007 . The results are plotted in the top panel of Figure 4. The solid line shows point estimates of the coefficients $\beta_{j}$. We do not observe any significant differences between the private equity-owned and other for-profit groups before 2007. The coefficients are near and not distinguishable from 
zero. After 2007, borrowing increases faster at private equity-owned schools.

It is possible that this increase in borrowing is beneficial to students. Indeed, Goodman et al. (2017) find that many young borrowers are credit constrained and use student loans as an additional source of liquidity. However, if schools are raising tuition to capture credit expansions, this is unlikely to benefit students. Table 4 Panel 2 presents regression results for tuition. We see sharp increases in tuition that completely offset the increase in borrowing. Figure 4 Panel B also shows that there was no pre-trend; the timing of the limit increase coincides with the tuition hike. ${ }^{21}$

In the Appendix, we conduct two additional tests for subsidy capture. One shows that private equity-owned schools are better at avoiding a threshold that determines access to federal aid. The other shows that the market values of publicly traded for-profits are extremely sensitive to unfettered access to federal aid. They fell sharply when rules were announced that aimed to tie this access to student labor market performance, and then rose sharply when these rules were substantially weakened.

In sum, we find that private equity-held schools raise tuition and borrowing at a faster rate following loan limit increases, consistent with these institutions being better at capturing government aid. Their superior ability to capture this strategic opportunity is also evidence of operational changes; in particular, different management that engages in rent-seeking behavior. The expanded capture of government subsidies and guaranteed loans naturally leads to higher profitability (Bachas, Kim, and Yannelis 2019).

\section{Buyouts and Student Outcomes}

We have thus far established that private equity ownership increases capture of government aid, which is an adverse outcome from the taxpayer perspective. We now turn to a second group of stakeholders, students, who are the consumers and have different interests from equity holders, potentially leading to the violation of implicit contracts (Shleifer and Summers 1988, Appelbaum

\footnotetext{
${ }^{21}$ Additionally, Appendix Table B4 shows that there is no increase in faculty student ratios, suggesting that additional tuition increases are not being passed on to higher institutional quality.
} 
and Batt 2014). Private equity general partners may be more disposed than the pre-existing owners to violate implicit contracts for three reasons. First, they are new owners and do not have the same established relationships or commitments. Second, their compensation structure incentivizes rapidly increasing operating profits and firm value in the service of a short-term exit. Third, they have less exposure to potential long-term liabilities from implicit contract violations, such as regulatory backlash or reputation effects.

This section first examines how private equity buyouts affect the student outcomes of graduation rates, loan repayment and earnings. Section 5.2 then considers two mechanisms for the effects: First, private equity firms may select schools on different trends; and second, the change in ownership may affect the composition of students. A third possibility is that buyouts affect students through changed operations. This is considered in Section 6. These three mechanisms are not mutually exclusive.

\subsection{Effect of Buyouts on Student Outcomes}

Graduation rates are a standard measure of school performance in the education literature, as failing to graduate is unambiguously detrimental to affected students (Bowen, Chingos, and McPherson 2009, Stinebrickner and Stinebrickner 2012, Arcidiacono et al. 2016). It may also harm their peers who do graduate if the degree is perceived as lower quality by employers. For example, in an experimental setting, Deming et al. (2016) show that employers prefer candidates with degrees from programs that have higher graduation rates.

The graduation rate metric that we observe is the share of students who graduate within 150 percent of the degree's normal time. This only includes full-time students (who are also the vast majority of students at for-profit colleges), so taking longer to get a degree does not mean that a student is working in the labor force and taking a light course load (see Gilpin and Stoddard 2017). Relatedly, Bound, Lovenheim, and Turner (2007) show that lower graduation rates do not reflect a longer time to degree or greater human capital acquisition (i.e., more credits); instead, longer times to degree are associated with dropping out and worse labor market outcomes. However, we cannot 
strictly rule out the possibility that students are taking longer to graduate, which could generate higher profits for schools if the students are paying tuition.

In Table 5 Panel 1, we show that private equity buyouts lead to a six-percentage point decline in graduation rates, or about 13 percent of the mean across all schools. This relationship is consistent across models, though the matching estimate is somewhat lower. Figure 5 Panel A contains the event study plot. As in the following figure for loan repayment, it omits the year before the buyout because these students are partially treated, which we examine below. Both panels reveal a negative effect on graduation rates. The effect is immediate, which is consistent with the fact that the buyout year is the first affected academic year. Given that the majority of programs are one-year programs, operational changes can take effect quickly. Falling graduation rates could be profit maximizing for schools, particularly for one-year programs, even if they are bad for affected students. The school receives tuition from the government (and the student acquires debt) when the student has been in class for just one week at the semester's start. If the student drops out, the school no longer bears the instructional, service, and facilities costs associated with her attendance.

For the vast majority of borrowers, defaulting on student loans is an adverse outcome relative to repaying. This is in part because federal student debt is effectively non-dischargeable in bankruptcy, so wages may be garnished. The share of students in repayment, shown in Table 5 Panel 1, decreases after the buyout by 3.5 percentage points (column 4), relative to a mean across all schools of 53 percent. The visual event study in Figure 5 Panel B shows a downward trend after the buyout.

Private equity buyouts are associated with 6.1 percent lower within-cohort average earnings six years after enrollment, relative to a mean across all schools of $\$ 31,269$, in 2015 dollars (Table 5 Panel 2 column 1). Median earnings decline by a similar, albeit slightly smaller amount (columns 3-4). There are insufficient data for the matching estimator. ${ }^{22}$ Earnings exhibit strong time trends, increasing over most of our sample period and decreasing in the Great Recession. Therefore, we

\footnotetext{
${ }^{22}$ This is because we only observe six cohorts (as described in Section 2.3). We would need to match on the year prior to the buyout only for schools where, two years later, we have cohort wage data. There is inadequate data to conduct a match that improves meaningfully on the within-school, composition-controlled regressions.
} 
graph coefficients from a fixed effects regression in Appendix Figure B7. The results contain no pre-trends and indicate a deterioration after the buyout in log earnings.

\subsection{Selection and Student Body Composition}

Screening ability, where the private equity firms choose targets that would have changed anyway (i.e., with no buyout), could explain the effects on graduation rates, repayment rates, and earnings. This selection mechanism is most plausible when the target firm is on a trajectory towards the post-buyout outcomes during the pre-buyout years. Instead, the visual event studies presented in this section as well as subsequently when we discuss operational changes are largely devoid of pre-trends. They instead reveal discontinuities in levels and trends immediately around the buyout year. Though we cannot rule out some influence of selection, a selection mechanism is unlikely to fully explain the results.

Private equity ownership could also change the type of students that enroll. For example, new students may be less well qualified, with poorer labor market potential. This would be a causal effect of the buyouts, but has potentially different implications for value-added. Inconsistent with a composition mechanism, demographic controls do not significantly attenuate the results for any outcomes. We also find no effect of private equity buyouts on Pell grants per student or the share of students on federal grants, and the small negative effect on the share of students who are white is not robust to the matching estimator (Appendix Table B5). Therefore, observable demographic changes to the student body do not explain the main results.

We hold fixed composition using cohorts that are already enrolled at the school before the private equity acquisition occurs. We restrict the sample to two-year programs at ultimately private equity-owned schools. We compare the cohort that enrolled the year before the first private equityowned year with the earlier cohort that enrolled two years before. The former cohort had one year of private equity treatment, while the latter had zero. We can conduct this test only for graduation and repayment rates. ${ }^{23}$ The results are in Table 6 . The partially treated cohorts experience a 3.6

\footnotetext{
${ }^{23}$ There is inadequate earnings data (it only exists for six cohorts spaced three years apart). It is also not possible
} 
percentage point decline in graduation rates, slightly more than half the main effect among fullytreated cohorts. There is a large effect on repayment rates, at 5.4 percentage points. Thus, a changing student body composition cannot explain the declines in graduation and repayment rates.

We cannot rule out that different mechanisms may explain the falling graduation rates among the partially treated and subsequent cohorts. However, the effects among partially treated cohorts is at least suggestive of quality decline. The student chose to enroll in the program and pay substantial up-front tuition, mostly through loans that are non-dischargeable in bankruptcy. Presumably students making these investments believed that the degree is valuable when they enrolled. In the following section, we show immediate and enduring declines in measures of education inputs. This makes it unlikely that quality initially declined, leading more already enrolled students to drop out, and then rebounded such that composition effects explain the results among subsequent cohorts.

\section{Operational Mechanisms}

To fully understand how private equity buyouts create firm value in higher education, we examine operational mechanisms that may explain the increase in profits shown in Section 4 and the deterioration in student outcomes observed in Section 5. In this section, we consider six areas of operational change: education inputs, enrollment, recruiting/sales, governance, online education, and degree cuts. Finally, we examine whether chain acquisitions yield similar effects as private equity buyouts (Section 6.7).

\subsection{Education Inputs}

One possible mechanism is that education quality declines. Though we do not observe education quality directly, we show that measures of education inputs fall after private equity buyouts in Table 7. The number of full-time faculty per 100 full-time students falls by 0.45 (Panel 1 column for student loans, considered below, because they are measured only in the cohort's first year, in which they are either fully treated or not treated at all. 
1), relative to a mean of 5.3 across all schools. The matching estimate is smaller and imprecise (column 3). The share of expenditure devoted to instruction declines by about three percentage points (columns 4-5), relative to a mean across all schools of 48 percent. Here the matching estimate is significant and larger (column 6). The visual event studies, in Appendix Figure B7, reveal that education inputs decline in the first year after the buyout and continue to decline through the sixth year thereafter. This decline in education inputs is consistent with case studies in a U.S. Senate report, which documents that reductions in student support following private equity buyouts had negative impacts on educational quality with implications for student outcomes (Senate 2012). We summarize these in Appendix A.4. Notably, student complaints consistently point to a heavy reliance on part-time instructors with minimal certification and high instructional staff turnover rates.

These declines in education inputs may be responsible for the deterioration in student outcomes that we observe. Bound et al. (2010) find that lower institutional resources per student, including the number of faculty, have contributed more than compositional changes to the overall decline in college graduation rates. Motivated by their analysis, we examine the association between education inputs and graduation rate changes immediately after buyouts. If operational changes are responsible for deteriorating outcomes, education quality declines should correlate with graduation rate declines. Appendix Figure B9 Panels A and B show that this is the case: in the year around the buyout, schools that decrease their faculty-to-student ratio or instruction share of spending experience graduation rate declines, while schools that increase these education inputs experience graduation rate increases. Regressions in Appendix Table B6 also find that the negative effect of private equity on graduation rates in the year after the buyout is larger for schools with large negative changes in their faculty to student ratios.

This exercise also helps to explain the immediacy of the effects of buyouts on graduation rates. Firms can implement operational changes, particularly those that involve labor, relatively quickly. There is no reason that actions such as reducing the number of faculty and reallocating resources from instruction to sales would require more than a few months, in time for the buyout to impact 
what we term the first affected academic year. Adjustments involving fixed capital, such as the school's physical plant, might be expected to take years.

Tuition hikes could also explain the fall in graduation rates if students who are already enrolled decide that the program does not merit higher costs. While this explanation is intuitive, two institutional features related to the incentive problems in education suggest that tuition may not play a significant role. First, just over half the programs in our data last one year. Since payment is up-front, there are no tuition savings from dropping out mid-year. Second, students are price inelastic because the size of their loan package is not salient at the time of borrowing, and they have no reason to be sensitive to grant amounts (Bleemer et al. 2017). Consistent with this, we find no relationship between changes in tuition and graduation rates immediately around the buyout year (Appendix Figure B9 Panel C).

\subsection{Enrollment}

Boucly, Sraer, and Thesmar (2011) find that private equity buyouts of privately held firms relax financial constraints at the target firms. In education, better access to capital can support investments needed to achieve rapid enrollment growth. Indeed, we find that after a buyout, the number of full-time equivalent enrolled students increases by about 40 percent in the OLS regressions, and twice this amount in the matching estimator (Table 7 Panel 2 columns 1-3). The visual event study shows that the increase begins in the second year after the buyout, which contrasts with the impacts on student outcomes that occur immediately (Appendix Figure B10).

In light of the negative effects on student success measures, buyouts are unlikely to make existing student types (i.e., that would have enrolled before the buyout) weakly better off. However, whether additional students - regardless of their preparedness - are better or worse off as a result of the buyout depends on their outside option. In Appendix D, we show that additional students enrolled as a result of expansion after buyouts appear to be drawn away from attending community colleges, which tend to have higher labor market returns than for-profit colleges (Cellini and Turner 2016). To the degree the additional students would have attended community college, they are 
likely not better off.

\subsection{Recruiting and Sales}

It is puzzling that demand (i.e. enrollment) increases while education quality and student outcomes decline. One explanation is that private equity-owned schools invest in sales and marketing operations to attract more students, as suggested by their much higher share of employees in sales (Figure 2). These activities are typically technology-intensive, relying on carefully targeted online and phone strategies (Cottom 2017). They may be an area where private equity ownership enables investment in technology to advance growth, as in Boucly, Sraer, and Thesmar (2011) and Agrawal and Tambe (2016).

One way to observe the degree to which schools are more aggressively recruiting is to examine law enforcement actions, which are primarily related to recruiting violations, including predatory and misleading marketing, and the use of excessive commissions or quotas for salespeople. ${ }^{24}$ The chances of a school having its first law enforcement action increase dramatically after a private equity buyout. The dependent variable in columns 4-5 of Table 7 Panel 2 is one if the school experienced its first action in a given year. The coefficient is .0036 , significant at the .01 level, relative to a mean of .004. A visual comparison is in Appendix Figure B11. There are insufficient observations for the matching estimator.

\subsection{Governance}

Private equity investors often add value to their portfolio companies by changing governance (Kaplan and Strömberg 2009, Bloom et al. 2015). They exert control by joining the board of the portfolio firm and actively supervising portfolio firm managers (Cornelli and Karakaş 2015). At smaller privately held firms, the new owners may bring in experts in, for example, sales and

\footnotetext{
${ }^{24}$ An example comes from a U.S. Senate case study of a school acquired by Warburg Pincus. In the years after the buyout, marketing and recruitment comprised 39 percent of expenditures. Students complained that they were deceived about financial aid and whether the program would provide adequate certification for occupational licenses, and a former recruiter testified that "If we don't have a degree they want, we are supposed to convince them that one of ours will work for them anyway" (Senate $(2012,305)$ ). Four students submitted complaints that (Senate, 2012, 306).
} 
marketing. Gompers, Kaplan, and Mukharlyamov (2016) find that 31 percent of private equity investors recruit their own senior management teams before investing, which then replace the pre-buyout management team. We expect that private equity buyouts may affect operations through changes in management. We test this hypothesis in Table 7 Panel 1 column 7 , where the dependent variable is an indicator for whether a school's Chief Executive changes within three years of the buyout. ${ }^{25}$ We find 5.2 percentage point effect. The sample mean is 10.5 percent, indicating that private equity buyouts increase CEO turnover by about fifty percent, to roughly half of the average found in Gompers et al. (2016). Our results indicate that private equity owners more often change management, providing one channel for changed operations and increased firm value.

\subsection{Online Schools}

As mentioned above, greater access to capital and managerial expertise may lead to informational technology upgrades under private equity ownership (Agrawal and Tambe 2016). In our context, this could manifest in the expansion of online education, which might improve educational delivery and benefit students. For example, online education could reduce transportation costs for students and make enrollment possible for students who found transportation costs prohibitive. For the school, online education's low marginal costs per student presents opportunities for economies of scale.

We show the effect of private equity ownership on a school's probability of transitioning from primarily brick-and-mortar to online in Table 7 Panel 2 columns 6-7. The effect is economically small and somewhat imprecise, significant at only the .1 level (the matching estimator is not possible here). In unreported analysis, we find that the effects on education inputs and student outcomes are robust to excluding online schools. We also find no effect of private equity on the intensive margin, measured as the number of out-of-state students (or "distance" learners). While

\footnotetext{
${ }^{25}$ As defined in IPEDS, College Chief Executives are typically university presidents or another type of senior academic official. We define a Chief Executive change as an indicator of whether the last name of the Chief Executive listed in IPEDS changes from the previous year.
} 
we cannot rule out that one reason for the decline in the number of faculty is the addition of video or online learning, in general, the expansion of online education does not appear to explain the general patterns observed in the data, including the decline in labor inputs shown in Section 6.1.

\subsection{Degree cuts}

A potential operational change that might help explain the immediate fall in graduation rates is the elimination of degree programs. If private equity owners reduce degree offerings, students already enrolled in a cut program might be forced to drop out. In such a case, the effects that we show in the cohort partial treatment test, where composition effects are held fixed, might in fact reflect degree program cuts. We test this by identifying degree programs that are cut each year. We define a degree cut as a school-year in which there were no graduates of the degree, following a previous year with positive graduates. Appendix Figure B12 shows the number of degree cuts by year around the private equity buyout, within schools that switched to private equity ownership. We separately consider one, two, and four-year programs. In no case is there an observable increase in the years following the buyout. Appendix Table B7 confirms this in regression analysis. Private equity ownership does not lead to cuts to degrees offered, so this cannot explain the immediate decline in graduation rates.

\subsection{Private equity as an ownership type}

A final step is to confirm the basic mechanism for our findings, which is that private equity ownership confers distinct incentives. If the results are driven by changes in management and control rather than the particular approach of private equity to value creation, we expect similar effects in transitions to chain ownership. To consider this, we create two new variables. First, we define a "chain" as any parent company (SystemID) that is not private equity-owned and that owns at least two schools (UnitIDs). These ownership changes are included as a separate indicator variable. Second, we restrict the "private equity buyout" indicator to instances where a private equity-owned school system acquires an independent school. This enables a more 
apples-to-apples comparison with non-private equity chain acquisitions. The results are in Appendix Table B8. The effects of chain acquisitions are smaller and in many cases insignificant. However, they have a substantial negative effect on graduation rates and earnings, as well as a strong positive effect on enrollment. The results suggest a hierarchy of incentives and outcomes. Chains likely have more sophisticated corporate structures and arms-length owners than stand-alone, independent schools, giving them somewhat higher-powered incentives. Private equity ownership yields higher-powered incentives and leads to more adverse student outcomes.

We also examine variation among private equity firms. We find very similar results to the main model when we include lead private equity firm fixed effects. We also do not find that the effects vary by private equity firm characteristics, such as having a specialty in education, or being especially high- or low-performing. Finally, we find that our results are robust to omitting the largest three deals. ${ }^{26}$

\section{Conclusion}

This paper shows that private equity buyouts lead to higher profits, tuition, and borrowing. They also lead to lower education inputs, graduation rates, repayment rates, and earnings. We show that following a government credit expansion, private equity-owned schools raise tuition faster than other schools, which increases student debt. Superior federal aid capture is a key channel for highpowered incentives to translate to higher firm value. We do not conduct a welfare analysis and cannot rule out that some students are made better off by the buyouts, but it seems that a focus on maximizing revenue from subsidies helps to explain the average declines in student outcomes that we observe.

For-profit schools originally participated in an implicit contract: in exchange for federal grant and loan inputs, the school would increase the human capital of its students. Shleifer and Summers

\footnotetext{
${ }^{26}$ We define "large" as the number of schools (UnitIDs) purchased in the deal and subsequently acquired by the private equity-owned school system. The largest three are Empire Beauty Schools, which ultimately consisted of 82 schools, Corinthian (63 schools), and EDMC (49 schools).
} 
(1988) argue, in the context of hostile takeovers, that changes in ownership increase firm market value because they enable a transfer of rents from stakeholders (e.g., employees) to shareholders, and that such redistribution can destroy value from a social perspective. This paper focuses on two groups of consumer stakeholders in for-profit higher education: students and the government. From the private equity investor's perspective, it may be ex-post optimal to renege on the implicit contracts with them. In fact, students and the government differ from employees in ways that may increase the appeal of reneging; students typically purchase a degree-program only once, and the government has largely not been a demanding counter-party.

The existing literature on private equity has focused on sectors characterized by high levels of competition and product transparency, and low levels of government subsidy. Private equity groups have in recent decades invested significantly in sectors such as healthcare, education, defense and infrastructure, which are characterized by low levels of competition, product opacity, and high levels of government subsidy. Ours is the first study to focus on private equity investments in a heavily subsidized industry, and contrasts with much of the existing literature. Future work might study the role of private equity in industries with less competitive market structures. 


\section{References}

Adelino, M., K. Lewellen, and A. Sundaram (2015). Investment decisions of nonprofit firms: Evidence from hospitals. The Journal of Finance 70(4), 1583-1628.

Agrawal, A. and P. Tambe (2016). Private equity and workers' career paths: the role of technological change. The Review of Financial Studies 29(9), 2455-2489.

Appelbaum, E. and R. Batt (2014). Private equity at work: When Wall Street manages Main Street. Russell Sage Foundation.

Arcidiacono, P., E. Aucejo, A. Maurel, and T. Ransom (2016). College attrition and the dynamics of information revelation. NBER Working Paper No. 22325.

Arcidiacono, P., J. Holz, A. Maurel, and T. Romano (2014). Modeling college major choices using elicited measures of expectations and counterfactuals. Journal of Econometrics 166(1), 3-16.

Armona, L., R. Chakrabarti, and M. F. Lovenheim (2017). How does for-profit college attendance affect student loans, defaults and earnings? NBER Working Paper No. 25042.

Bachas, N., O. Kim, and C. Yannelis (2019). Loan guarantees and credit supply.

Bernstein, S., J. Lerner, and F. Mezzanotti (2017). Private equity and financial fragility during the crisis. NBER Working Paper No. 23626.

Bernstein, S. and A. Sheen (2016). The operational consequences of private equity buyouts: Evidence from the restaurant industry. Review of Financial Studies 29(9), 2387-2418.

Bertrand, M., E. Duflo, and S. Mullainathan (2004). How much should we trust differences-indifferences estimates? The Quarterly Journal of Economics 119(1), 249-275.

Bettinger, E. P., B. T. Long, P. Oreopoulos, and L. Sanbonmatsu (2012). The role of application assistance and information in college decisions results from the H\&R Block FAFSA experiment. The Quarterly Journal of Economics 127(3), 1205-1242.

Bleemer, Z., M. Brown, D. Lee, K. Strair, and W. van der Klaauw (2017). Echoes of rising tuition in students borrowing, educational attainment, and homeownership in post-recession America. Federal Reserve Bank of New York Staff Report.

Bloom, N., R. Sadun, and J. Van Reenen (2015). Do private equity owned firms have better management practices? The American Economic Review 105(5), 442-446.

Boucly, Q., D. Sraer, and D. Thesmar (2011). Growth LBOs. Journal of Financial Economics 102(2), 432-453.

Bound, J., M. Lovenheim, and S. Turner (2007). Understanding the decrease in college completion rates and the increased time to the baccalaureate degree. Population Studies Center Research Report 7, 626.

Bound, J., M. F. Lovenheim, and S. Turner (2010). Why have college completion rates declined? An analysis of changing student preparation and collegiate resources. American Economic Journal: Applied Economics 2(3), 129-57.

Bound, J. and S. Turner (2007). Cohort crowding: How resources affect collegiate attainment. Journal of Public Economics 91(5-6), 877-899. 
Bowen, W. G., M. M. Chingos, and M. S. McPherson (2009). Crossing the finish line: Completing college at America's public universities, Volume 52. Princeton University Press.

Brown, G. W., O. Gredil, and S. N. Kaplan (2013). Do private equity funds game returns? Working Paper.

Cao, J. and J. Lerner (2009). The performance of reverse leveraged buyouts. Journal of Financial Economics 91(2), 139-157.

Cellini, S., R. Darolia, and L. Turner (2017). Where do students go when for-profit colleges lose federal aid? Working Paper.

Cellini, S. R. and L. Chaudhary (2014). The labor market returns to a for-profit college education. Economics of Education Review 43, 125-140.

Cellini, S. R. and C. Goldin (2014). Does federal student aid raise tuition? New evidence on for-profit colleges. American Economic Journal: Economic Policy 6(4), 174-206.

Cellini, S. R. and N. Turner (2016). Gainfully employed? Assessing the employment and earnings of for-profit college students using administrative data. NBER Working Paper No. 22287.

CFBP (2012). Private student loans report. Report to the U.S. Senate.

Clemens, J. and J. D. Gottlieb (2014). Do physicians' financial incentives affect medical treatment and patient health? American Economic Review 104(4), 1320-49.

Cohn, J., N. Nestoriak, and M. Wardlaw (2017). Private equity buyouts and workplace safety. Working Paper.

Cornelli, F. and O. Karakaş (2015). CEO turnover in LBOs: The role of boards. Working Paper.

Cottom, T. M. (2017). Lower ed: The troubling rise of for-profit colleges in the new economy. New Press, The.

Dafny, L., K. Ho, and R. S. Lee (2016). The price effects of cross-market hospital mergers. NBER Working Paper No. 22106.

Davis, S. J., J. Haltiwanger, K. Handley, R. Jarmin, J. Lerner, and J. Miranda (2014). Private equity, jobs, and productivity. The American Economic Review 104(12), 3956-3990.

Deming, D. J., C. Goldin, and L. F. Katz (2012, dec). The for-profit postsecondary school sector: Nimble critters or agile predators? Journal of Economic Perspectives 26(1), 139-64.

Deming, D. J., N. Yuchtman, A. Abulafi, C. Goldin, and L. F. Katz (2016). The value of postsecondary credentials in the labor market: An experimental study. The American Economic Review 106(3), 778-806.

Duggan, M. G. (2000). Hospital ownership and public medical spending. The Quarterly Journal of Economics 115(4), 1343-1373.

Eaton, C., J. Habinek, A. Goldstein, C. Dioun, D. G. Santibáñez Godoy, and R. Osley-Thomas (2016). The financialization of US higher education. Socio-Economic Review 14(3), 507-535.

Ewens, M., M. Rhodes-Kropf, and I. A. Strebulaev (2016). Insider financing and venture capital returns. Working Paper.

Fracassi, C., A. Previtero, and A. Sheen (2017). Is private equity good for consumers? Working 


\section{Paper.}

GAO (2014). Federal student loans: Impact of loan limit increases on college prices is difficult to discern. United States Government Accountability Office Report GAO-14-7.

Gilpin, G. and C. Stoddard (2017). Does regulating for-profit colleges improve educational outcomes? What we know, what we don't know, and what we need to find out. Journal of Policy Analysis and Management 36(4), 942-950.

Glaeser, E. L. and A. Shleifer (2001). Not-for-profit entrepreneurs. Journal of Public Economics 81(1), 99-115.

Gompers, P., S. N. Kaplan, and V. Mukharlyamov (2016). What do private equity firms say they do? Journal of Financial Economics 121(3), 449-476.

Goodman, S., A. Isen, and C. Yannelis (2017). A day late and a dollar short: Limits, liquidity and household formation for student borrowers. Working Paper.

Guo, S., E. S. Hotchkiss, and W. Song (2011). Do buyouts (still) create value? The Journal of Finance 66(2), 479-517.

Hackmann, M. B. and R. V. Pohl (2018). Patient vs. provider incentives in long term care. NBER Working Paper No. 25178.

Hansmann, H. B. (1980). The role of nonprofit enterprise. The Yale Law Journal 89(5), 835-901.

Hart, O., A. Shleifer, and R. W. Vishny (1997). The proper scope of government: Theory and an application to prisons. The Quarterly Journal of Economics 112(4), 1127-1161.

Hastings, J., C. Nielson, and S. Zimmerman (2017). The effects of earnings disclosure on college enrollment decisions. Working Paper.

Holmstrom, B. and S. N. Kaplan (2001). Corporate governance and merger activity in the United States: Making sense of the 1980s and 1990s. Journal of Economic Perspectives 15(2), 121-144.

ICAS. Steps the Education Department should immediately take to curb default rate manipulation. Technical report.

Jensen, M. C. (1989). Eclipse of the public corporation. Harvard Business Review.

Kaplan, S. (1989). The effects of management buyouts on operating performance and value. Journal of Financial Economics 24(2), 217-254.

Kaplan, S. N. and P. Strömberg (2009). Leveraged buyouts and private equity. The Journal of Economic Perspectives 23(1), 121-146.

Kelchen, R. (2017, January). How much do for-profit colleges rely on federal funds? Brookings Institution Chalkboard.

Krishnan, K. and P. Wang (2017). The cost of financing education: Can student debt hinder entrepreneurship? Working Paper.

Lang, K. and R. Weinstein (2013). The wage effects of not-for-profit and for-profit certifications: Better data, somewhat different results. Labour Economics 24, 230-243.

Lerner, J. and A. Schoar (2005). Does legal enforcement affect financial transactions? The contractual channel in private equity. The Quarterly Journal of Economics 120(1), 223-246. 
Liu, Y. T. and C. Belfield (2014). The labor market returns to for-profit higher education: Evidence for transfer students. A CAPSEE Working Paper. Center for Analysis of Postsecondary Education and Employment.

Ljungqvist, A., L. Persson, and J. Tag (2016). Private equity's unintended dark side: On the economic consequences of excessive delistings. Working Paper.

Looney, A. and C. Yannelis (2015). A crisis in student loans? How changes in the characteristics of borrowers and in the institutions they attended contributed to rising loan defaults. Brookings Papers on Economic Activity, 1-89.

Lucca, D. O., T. Nadauld, and K. Shen (2016). Credit supply and the rise in college tuition: Evidence from the expansion in federal student aid programs. Working Paper.

Ma, W., P. Ouimet, and E. Simintzi (2018). Mergers and acquisitions, technological change and inequality. Working Paper.

Matsa, D. A. (2011). Running on empty? financial leverage and product quality in the supermarket industry. American Economic Journal: Microeconomics 3(1), 137-73.

Metrick, A. and A. Yasuda (2010). The economics of private equity funds. The Review of Financial Studies 23(6), 2303-2341.

Mueller, H. and C. Yannelis (2019). The rise in student loan defaults. Journal of Financial Economics 131(1), 1-19.

Muscarella, C. J. and M. R. Vetsuypens (1990). Efficiency and organizational structure: A study of reverse LBOs. The Journal of Finance 45(5), 1389-1413.

Senate (2012). For profit higher education: The failure to safeguard the federal investment and ensure student success.

Shleifer, A. and L. H. Summers (1988). Breach of trust in hostile takeovers. In Corporate Takeovers: Causes and Consequences, pp. 33-68. University of Chicago Press.

Sloan, F. A., G. A. Picone, D. H. Taylor, and S.-Y. Chou (2001). Hospital ownership and cost and quality of care: is there a dime's worth of difference? Journal of Health Economics 20(1), 1-21.

Stinebrickner, R. and T. Stinebrickner (2013). A major in science? Initial beliefs and final outcomes for college major and dropout. Review of Economic Studies 83(1), 426-472.

Stinebrickner, T. and R. Stinebrickner (2012). Learning about academic ability and the college dropout decision. Journal of Labor Economics 30(4), 707-748.

Webber, D. A. and R. G. Ehrenberg (2010). Do expenditures other than instructional expenditures affect graduation and persistence rates in American higher education? Economics of Education Review 29(6), 947-958.

Wiswall, M. and B. Zafar (2014). Determinants of college major choice: Identification using an information experiment. Review of Economic Studies 82(2), 791-824. 
Table 1: Descriptive Statistics by Institution Type

\begin{tabular}{|c|c|c|c|c|}
\hline & Nonprofit, State & Community & For profit, not PE & PE owned \\
\hline & $\begin{array}{c}\text { Mean } \\
\text { (Std Dev) }\end{array}$ & $\begin{array}{c}\text { Mean } \\
\text { (Std Dev) }\end{array}$ & $\begin{array}{c}\text { Mean } \\
\text { (Std Dev) }\end{array}$ & $\begin{array}{c}\text { Mean } \\
\text { (Std Dev) }\end{array}$ \\
\hline Schools per firm & 1.03 & 1.05 & 1.49 & 8.07 \\
\hline & $(0.45)$ & $(0.62)$ & $(4.19)$ & (11.49) \\
\hline Operating margin (mill 2015\$) & 40 & 6 & 6 & 34 \\
\hline & (102) & (16) & (34) & (63) \\
\hline Publicly traded & 0.00 & 0.00 & 0.14 & 0.000 \\
\hline & $(0.000)$ & $(0.00)$ & $(0.35)$ & $(0.00)$ \\
\hline Selective admissions & 0.68 & 0.089 & 0.092 & 0.077 \\
\hline & $(0.467)$ & $(0.29)$ & $(0.29)$ & $(0.27)$ \\
\hline Highest degree offered ${ }^{* *}$ & 1.12 & 2.12 & 2.32 & 2.01 \\
\hline & $(0.40)$ & $(0.33)$ & $(0.75)$ & $(0.723)$ \\
\hline Graduation rate* & 0.52 & & 0.55 & 0.48 \\
\hline & $(0.21)$ & & $(0.25)$ & $(0.21)$ \\
\hline Repayment rate $(3 \text { year })^{\dagger}$ & 0.64 & 0.46 & 0.41 & 0.34 \\
\hline & $(0.17)$ & $(0.13)$ & $(0.16)$ & $(0.14)$ \\
\hline Mean earnings after school (2015\$) & 49,067 & 36,915 & 31,769 & 33,523 \\
\hline & $(15,121)$ & $(7,9394)$ & $(11,254)$ & $(11,125)$ \\
\hline Full-time faculty per 100 students $^{ \pm}$ & 6.28 & 4.38 & 4.48 & 3.62 \\
\hline & $(4.653)$ & $(4.26)$ & $(4.1)$ & $(2.66)$ \\
\hline Full-time faculty & 261 & 109 & 16 & 25 \\
\hline & (465) & $(110)$ & (29) & (45) \\
\hline Share spending on instruction & 0.47 & 0.54 & 0.42 & 0.36 \\
\hline & $(0.14)$ & $(0.13)$ & $(0.24)$ & $(0.15)$ \\
\hline Spending on instruction (mill 2015 \$) & 38 & 17 & 2 & 4 \\
\hline & (70) & (23) & (6) & (7) \\
\hline Students ${ }^{\ddagger}$ & 3,885 & 3,148 & 387 & 747 \\
\hline & $(5,656)$ & $(3,866)$ & $(1,232)$ & $(1,413)$ \\
\hline
\end{tabular}


Table 1 continued

\section{Nonprofit, State Community For profit, not PE PE owned}

$\begin{array}{lcccc} & \begin{array}{c}\text { Mean } \\ \text { (Std Dev) }\end{array} & \begin{array}{c}\text { Mean } \\ \text { (Std Dev) }\end{array} & \begin{array}{c}\text { Mean } \\ \text { (Std Dev) }\end{array} & \begin{array}{c}\text { Mean } \\ \text { (Std Dev) }\end{array} \\ \text { 1st law enforcement action } & 0.00 & 0.00 & 0.00 & 0.004 \\ \text { Share students white } & (0.007) & (0.006) & (0.015) & (0.059) \\ & 0.67 & 0.69 & 0.51 & 0.44 \\ \text { Loan per borrower }(2015 \$) & (0.28) & (0.25) & (0.32) & (0.26) \\ & 5,177 & 4,008 & 6,700 & 8,124 \\ \text { Tuition revenue per student }(2015 \$) & (2,370) & (2,016) & (2,978) & (2,834) \\ \text { Online } & 10,996 & 3,673 & 14,211 & 17,521 \\ & (7,110) & (3,883) & (7,678) & (7,303) \\ \text { Pell grants per student }(2015 \$) & 0.000 & 0.000 & 0.016 & 0.027 \\ & (0.000) & (0.000) & (0.127) & (0.161) \\ \text { Share students with federal grant aid } & 1,351 & 1,726 & 4,109 & 4,609 \\ & (1,683) & (1,293) & (3,193) & (3,105) \\ & 0.40 & 0.50 & 0.67 & 0.72 \\ \text { N (school-year obs) } & (0.23) & (0.21) & (0.24) & (0.20)\end{array}$

Note: This table contains summary statistics at the school (UnitID, or campus) level. The exception is profits, which are at the firm/institution-year (SystemID) level; from left, $\mathrm{N}=47,834 ; 23,929 ; 8,254$; and 438. ${ }^{\ddagger}$ Full-time equivalent (applies to all below). ${ }^{*}$ Graduation rate is the share of students that graduate within 150 percent of normal time for programs of 2 years or less duration. ${ }^{ \pm}$Full-time faculty. ${ }^{\dagger}$ Share of students in repayment after three years (have paid back at least $\$ 1$ in principal). ${ }^{* *}$ Highest degree offered is 1 for 4 -year degrees and higher, 2 for 2 -year degrees, and 3 for less-than-2-year degrees and certificates. 
Dependent variable: Indicator for school experiencing private equity buyout in following year

Community colleges in $\mathrm{CZ}$

For-profits in $\mathrm{CZ}$

Log FTE students in CZ

Profit growth (last year)

Log profits

Log FTE students

3-yr repayment rate

Share students white

Year f.e.

$\mathrm{N}$

Pseudo $R^{2}$
(1)

(2)

$.023 * *$

$(.011)$

$-.0083 * *$

(.004)

$.11 *$

(.063)

$-.0014$

(.0011)

$.17 * * *$

(.043)

$.46 * * *$

(.059)

21436

.13

Y
(3)

(4)

$.05^{* *}$

(.022)

$-.035 * * *$

(.0084)

$.35 * *$

(.14)

$-.0015 \quad-.0036^{* *}$

$(.0011) \quad(.0015)$

$.19 * * * \quad .22 * * *$

(.043) (.081)

$.46 * * * \quad .42 * * *$

(.061) (.11)

$-4.7^{* * *}$

$-2.1 * * *$

(.72)

$-.55$

(.39)

(.18)

Y

Y

13738

20892

10340

.089

.13

.17

Note: This table shows estimates from logit regressions in which the dependent variable is an indicator for the schoolyear immediately preceding a private equity buyout. All other years for target schools are excluded from the sample. The sample is restricted to for-profit, non-publicly traded schools. Only variables with predictive power over buyouts are shown. 
Table 3: Private Equity Ownership and Financial Outcomes

Panel 1

\begin{tabular}{|c|c|c|c|c|c|c|}
\hline \multirow[t]{2}{*}{ Dependent variable: } & \multicolumn{3}{|c|}{ Tuition per student } & \multicolumn{3}{|c|}{ Loan per borrower } \\
\hline & (1) & (2) & $\begin{array}{c}\mathrm{NNM}^{ \pm} \\
\text {(3) }\end{array}$ & (4) & (5) & $\begin{array}{c}\mathrm{NNM}^{ \pm} \\
(6)\end{array}$ \\
\hline PE buyout & $\begin{array}{l}1610^{* *} \\
(612)\end{array}$ & $\begin{array}{c}1637 * * * \\
(574)\end{array}$ & $\begin{array}{c}2107 * * \\
(973)\end{array}$ & $\begin{array}{c}582 * * * \\
(186)\end{array}$ & $\begin{array}{l}591 * * * \\
(185)\end{array}$ & $\begin{array}{c}641 * * \\
(278)\end{array}$ \\
\hline Composition controls & $\mathrm{N}$ & $\mathrm{Y}$ & - & $\mathrm{N}$ & $\mathrm{Y}$ & - \\
\hline School type controls ${ }^{\dagger}$ & $\mathrm{Y}$ & $\mathrm{Y}$ & - & Y & $\mathrm{Y}$ & - \\
\hline School Fixed Effects & $\mathrm{Y}$ & $\mathrm{Y}$ & - & Y & $\mathrm{Y}$ & - \\
\hline Year Fixed Effects & $\mathrm{Y}$ & $\mathrm{Y}$ & - & $\mathrm{Y}$ & $\mathrm{Y}$ & - \\
\hline $\mathrm{N}$ & 102355 & 102355 & 9130 & 77497 & 77497 & 16767 \\
\hline$R^{2}$ & .82 & .84 & - & .67 & .67 & - \\
\hline
\end{tabular}

Panel 2

\begin{tabular}{|c|c|c|c|c|c|c|}
\hline \multirow[t]{3}{*}{ Dependent variable: } & \multicolumn{3}{|c|}{ Federal grants per student } & \multicolumn{3}{|c|}{ Log profits } \\
\hline & & & $\mathrm{NNM}^{ \pm}$ & & & $\mathrm{NNM}^{ \pm}$ \\
\hline & (1) & (2) & (3) & (4) & (5) & (6) \\
\hline PE buyout & $\begin{array}{c}837 * * * \\
(176)\end{array}$ & $\begin{array}{c}784 * * * \\
(219)\end{array}$ & $\begin{array}{l}1450 * * \\
(597)\end{array}$ & $\begin{array}{l}.57 * * * \\
(.14)\end{array}$ & $\begin{array}{c}.57 * * * \\
(.13)\end{array}$ & $\begin{array}{c}.93 * * * \\
(.17)\end{array}$ \\
\hline Composition controls ${ }^{\ddagger}$ & $\mathrm{N}$ & $\mathrm{Y}$ & - & $\mathrm{N}$ & $\mathrm{Y}$ & - \\
\hline School type controls ${ }^{\dagger}$ & $\mathrm{Y}$ & $\mathrm{Y}$ & - & $\mathrm{Y}$ & $\mathrm{Y}$ & - \\
\hline School Fixed Effects & $\mathrm{Y}$ & $\mathrm{Y}$ & - & $\mathrm{Y}$ & Y & - \\
\hline Year Fixed Effects & $\mathrm{Y}$ & $\mathrm{Y}$ & - & $\mathrm{Y}$ & $\mathrm{Y}$ & - \\
\hline $\mathrm{N}$ & 86412 & 86412 & 20947 & 104459 & 104459 & 17785 \\
\hline$R^{2}$ & .53 & .55 & - & .84 & .84 & - \\
\hline
\end{tabular}

Note: This table shows estimates of the effect of private equity ownership on financials (Panel 1) and on government aid-related student outcomes (Panel 2). Dependent variables are in millions of 2015\$ in Panel 1, and 2015\$ in Panel 2. ${ }^{ \pm}$Nearest-neighbor matching is done as in previous tables. Observations are at the SystemID-year level for profits, and the UnitID-year level elsewhere. ${ }^{\ddagger}$ We control for the share of students who are white, black, and Hispanic, and the average amount of federal Pell grants per student, a proxy for low-income students. ${ }^{\dagger}$ These are indicators for having selective admissions, public ownership, and are fixed effects for highest degree offered. The latter includes less than 2-year (certificate), 2-year, or 4-year. Standard errors two-way clustered by SystemID and year. Coefficients marked with $*, * *, * * *$, denote $\mathrm{p}<.1, \mathrm{p}<.05, \mathrm{p}<.01$, respectively. 
Table 4: Effect of Loan Limit Increase

Panel 1: Borrowing

Dependent Variable: Average loan per borrower (2015\$)

\begin{tabular}{lcccccc} 
& $(1)$ & $(2)$ & $(3)$ & $(4)$ & $(5)$ & $(6)$ \\
\cline { 2 - 6 } PE owned·Post 2007 & $909 * * *$ & $1110^{* * *}$ & $1086 * * *$ & $798 * * *$ & $1009 * * *$ & $967 * * *$ \\
& $(90)$ & $(95)$ & $(100)$ & $(97)$ & $(106)$ & $(112)$ \\
PE owned & $1743^{* * *}$ & & & $930 * * *$ & & \\
& $(99)$ & & & $(97)$ & & \\
Post 2007 & $2032^{* * *}$ & & & $2039 * * *$ & & \\
& $(24)$ & & & $(49)$ & & \\
& & & & & & \\
Controls & $\mathrm{N}$ & $\mathrm{N}$ & $\mathrm{Y}$ & $\mathrm{N}$ & $\mathrm{N}$ & $\mathrm{Y}$ \\
Sample & $\mathrm{All}$ & $\mathrm{All}$ & $\mathrm{All}$ & For-Profits & For-Profits & For-Profits \\
School Fixed Effects & $\mathrm{N}$ & $\mathrm{Y}$ & $\mathrm{Y}$ & $\mathrm{N}$ & $\mathrm{Y}$ & $\mathrm{Y}$ \\
Year Fixed Effects & $\mathrm{N}$ & $\mathrm{Y}$ & $\mathrm{Y}$ & $\mathrm{N}$ & $\mathrm{Y}$ & $\mathrm{Y}$ \\
$\mathrm{N}$ & 69056 & 69056 & 64969 & 29402 & 29402 & 26758 \\
$R^{2}$ & .29 & .68 & .68 & .29 & .63 & .63 \\
\hline
\end{tabular}

Panel 2: Tuition

Dependent Variable: Average tuition (2015\$)

(1)

(2)

$1656^{* * *}$

(262)

(247)

$5427 * * *$

(246)

Post 2007

$2472 * * *$

(55)

\begin{tabular}{lcccccc} 
Controls & $\mathrm{N}$ & $\mathrm{N}$ & $\mathrm{Y}$ & $\mathrm{N}$ & $\mathrm{N}$ & $\mathrm{Y}$ \\
Sample & All & All & All & For-Profits & For-Profits & For-Profits \\
School Fixed Effects & $\mathrm{N}$ & $\mathrm{Y}$ & $\mathrm{Y}$ & $\mathrm{N}$ & $\mathrm{Y}$ & $\mathrm{Y}$ \\
Year Fixed Effects & $\mathrm{N}$ & $\mathrm{Y}$ & $\mathrm{Y}$ & $\mathrm{N}$ & $\mathrm{Y}$ & $\mathrm{Y}$ \\
$\mathrm{N}$ & 63123 & 63123 & 59386 & 14156 & 14156 & 13835 \\
$R^{2}$ & .26 & .83 & .86 & .2 & .62 & .75 \\
\hline \hline
\end{tabular}

(3) (4) (5) (6)

\begin{tabular}{cccc}
$1310 * * *$ & $1193 * * *$ & $1238 * * *$ & $1161 * * *$ \\
$(215)$ & $(262)$ & $(308)$ & $(256)$ \\
& $1929 * * *$ & & \\
& $(268)$ & & \\
& $2708^{* * *}$ & & \\
& $(110)$ & & \\
& & & \\
Y & $\mathrm{N}$ & $\mathrm{N}$ & $\mathrm{Y}$ \\
All & For-Profits & For-Profits & For-Profits \\
$\mathrm{Y}$ & $\mathrm{N}$ & $\mathrm{Y}$ & $\mathrm{Y}$ \\
$\mathrm{Y}$ & $\mathrm{N}$ & $\mathrm{Y}$ & $\mathrm{Y}$ \\
59386 & 14156 & 14156 & 13835 \\
.86 & .2 & .62 & .75 \\
\hline
\end{tabular}

Note: This table shows the difference-in-difference estimate of the effect of the 2007 loan limit increase on borrowing, in Panel 1, and tuition, in Panel 2. Standard errors are clustered at the systemID level. Coefficients marked with $*$, $* *, * * *$, denote $\mathrm{p}<.1, \mathrm{p}<.05, \mathrm{p}<.01$, respectively. 
Table 5: Private Equity Ownership and Student Outcomes

Panel 1

\begin{tabular}{|c|c|c|c|c|c|c|}
\hline \multirow[t]{2}{*}{ Dependent variable: } & \multicolumn{3}{|c|}{$\begin{array}{l}\text { Graduation rate (share graduate } \\
\text { in } 150 \% \text { normal time) }\end{array}$} & \multicolumn{3}{|c|}{ Repayment rate ( 3 year) } \\
\hline & (1) & (2) & $\begin{array}{c}\mathrm{NNM}^{ \pm} \\
(3)\end{array}$ & (4) & (5) & $\begin{array}{c}\mathrm{NNM}^{ \pm} \\
(6)\end{array}$ \\
\hline PE buyout & $\begin{array}{c}-.06^{* * * *} \\
(.012)\end{array}$ & $\begin{array}{c}-.059 * * * \\
(.012)\end{array}$ & $\begin{array}{l}-.041 * \\
(.023)\end{array}$ & $\begin{array}{c}-.035^{* *} \\
(.011)\end{array}$ & $\begin{array}{l}-.032 * * \\
(.0091)\end{array}$ & $\begin{array}{r}-.057^{*} \\
(.032)\end{array}$ \\
\hline Composition controls ${ }^{\ddagger}$ & $\mathrm{N}$ & $\mathrm{Y}$ & - & $\mathrm{N}$ & $\mathrm{Y}$ & - \\
\hline School type controls ${ }^{\dagger}$ & $\mathrm{Y}$ & $\mathrm{Y}$ & - & $\mathrm{Y}$ & $\mathrm{Y}$ & - \\
\hline School Fixed Effects & $\mathrm{Y}$ & $\mathrm{Y}$ & - & $\mathrm{Y}$ & $\mathrm{Y}$ & - \\
\hline Year Fixed Effects & Y & $\mathrm{Y}$ & - & $\mathrm{Y}$ & $\mathrm{Y}$ & - \\
\hline $\mathrm{N}$ & 56965 & 56839 & 7883 & 28201 & 28201 & 4623 \\
\hline$R^{2}$ & .8 & .81 & - & .96 & .96 & - \\
\hline
\end{tabular}

Panel 2

\begin{tabular}{|c|c|c|c|c|}
\hline \multirow[t]{2}{*}{ Dependent variable: } & \multicolumn{2}{|c|}{ Log mean earnings } & \multicolumn{2}{|c|}{ Log 50th pctile earnings } \\
\hline & (1) & (2) & (3) & (4) \\
\hline PE buyout & $\begin{array}{c}-.061 * * * \\
(.013)\end{array}$ & $\begin{array}{l}-.05 * * \\
(.012)\end{array}$ & $\begin{array}{c}-.057 * * \\
(.017)\end{array}$ & $\begin{array}{c}-.043 * \\
(.016)\end{array}$ \\
\hline Composition controls ${ }^{\ddagger}$ & $\mathrm{N}$ & $\mathrm{Y}$ & $\mathrm{N}$ & $\mathrm{Y}$ \\
\hline School type controls ${ }^{\dagger}$ & $\mathrm{Y}$ & $\mathrm{Y}$ & $\mathrm{Y}$ & $\mathrm{Y}$ \\
\hline School Fixed Effects & $\mathrm{Y}$ & $\mathrm{Y}$ & $\mathrm{Y}$ & $\mathrm{Y}$ \\
\hline Year Fixed Effects & $\mathrm{Y}$ & $\mathrm{Y}$ & $\mathrm{Y}$ & $\mathrm{Y}$ \\
\hline $\mathrm{N}$ & 17736 & 17736 & 17736 & 17736 \\
\hline$R^{2}$ & .97 & .97 & .97 & .97 \\
\hline
\end{tabular}

Note: These panels show regression estimates (OLS) of the effect of private equity ownership on student outcomes, at the school (UnitID)-year level. ${ }^{ \pm}$Nearest-neighbor matching is done within the sample of other for-profit schools. The dependent variable is measured the year after the treated school's buyout. Matching is exactly on the year before the treated school's buyout, and then on characteristics. ${ }^{\ddagger}$ We control for the share of students who are white, black, and Hispanic, as well as the average amount of federal Pell grants per student, a proxy for low-income students. ${ }^{\dagger}$ Indicators for having selective admissions, public ownership, and fixed effects for highest degree offered. The latter includes less than 2-year (certificate), 2-year, or 4-year. Standard errors two-way clustered by SystemID and year. Coefficients marked with $*, * *, * * *$, denote $\mathrm{p}<.1, \mathrm{p}<.05, \mathrm{p}<.01$, respectively. 
Table 6: Cohort Partial Treatment Effect of Private Equity Ownership on Student Outcomes

\begin{tabular}{lcc} 
Dependent variable (3 year): & $\begin{array}{c}\text { Graduation rate } \\
\text { (share graduate in } \\
150 \% \text { normal time) }\end{array}$ & Repayment rate \\
& & \\
& & \\
& & $(1)$ \\
& & \\
PE buyout (partially treated cohort) & $-.036^{* * *}$ & $-.054^{* * * *}$ \\
& $(.012)$ & $(.013)$ \\
School type controls ${ }^{\dagger}$ & & \\
School Fixed Effects & $\mathrm{Y}$ & $\mathrm{Y}$ \\
Year Fixed Effects & $\mathrm{Y}$ & $\mathrm{Y}$ \\
& $\mathrm{Y}$ & $\mathrm{Y}$ \\
$\mathrm{N}$ & & \\
$R^{2}$ & 40088 & 21846 \\
\hline \hline
\end{tabular}

Note: These panels show regression estimates (OLS) of the partial treatment effect of private equity ownership on student outcomes, at the school (UnitID)-year level. We limit the sample to two cohorts in two-year programs: the cohort that enrolled in the year before the first private equity-owned year, and the cohort that enrolled two years before the first private equity-owned year. The variable "PE owned" is one for the former cohort, which had one year of private equity treatment, and zero for the earlier cohort, which had no private equity treatment. ${ }^{\dagger}$ Indicators for having selective admissions and public ownership. Standard errors two-way clustered by SystemID and year. Coefficients marked with $*, * *, * * *$, denote $\mathrm{p}<.1, \mathrm{p}<.05, \mathrm{p}<.01$, respectively. 
Table 7: Private Equity Ownership and Operational Outcomes

Panel 1

\begin{tabular}{|c|c|c|c|c|c|c|c|}
\hline \multirow[t]{3}{*}{ Dependent variable: } & \multicolumn{3}{|c|}{ Faculty per 100 students } & \multicolumn{3}{|c|}{ Instruction spending share } & \multirow[t]{2}{*}{ CEO* $^{*}$} \\
\hline & & & $\mathrm{NNM}^{ \pm}$ & & & $\mathrm{NNM}^{ \pm}$ & \\
\hline & (1) & (2) & (3) & (4) & (5) & (6) & (7) \\
\hline \multirow[t]{2}{*}{ PE buyout } & $-.45^{* *}$ & $-.36^{*}$ & -.2 & $-.028 *$ & $-.029 *$ & $-.049 * *$ & $0.0517 * *$ \\
\hline & $(.19)$ & $(.18)$ & $(.65)$ & $(.016)$ & $(.016)$ & $(.024)$ & $(0.0215)$ \\
\hline Composition controls ${ }^{\ddagger}$ & $\mathrm{N}$ & $\mathrm{Y}$ & - & $\mathrm{N}$ & $\mathrm{Y}$ & - & $\mathrm{N}$ \\
\hline School type controls ${ }^{\dagger}$ & $\mathrm{Y}$ & $\mathrm{Y}$ & - & $\mathrm{Y}$ & $\mathrm{Y}$ & - & $\mathrm{Y}$ \\
\hline School Fixed Effects & $\mathrm{Y}$ & $\mathrm{Y}$ & - & $\mathrm{Y}$ & $\mathrm{Y}$ & - & $\mathrm{Y}$ \\
\hline Year Fixed Effects & $\mathrm{Y}$ & $\mathrm{Y}$ & - & $\mathrm{Y}$ & $\mathrm{Y}$ & - & $\mathrm{Y}$ \\
\hline $\mathrm{N}$ & 62,432 & 62,432 & 7833 & 97401 & 97401 & 9343 & 99137 \\
\hline$R^{2}$ & 0.83 & 0.83 & - & .75 & .75 & - & .28 \\
\hline
\end{tabular}

Panel 2

Dependent variable:

\begin{tabular}{|c|c|c|c|c|c|c|}
\hline \multicolumn{3}{|c|}{ Log FTE students } & \multicolumn{2}{|c|}{ 1st law enf. action } & \multicolumn{2}{|c|}{ Online } \\
\hline (1) & (2) & $\begin{array}{c}\mathrm{NNM}^{ \pm} \\
\text {(3) }\end{array}$ & (4) & (5) & (6) & (7) \\
\hline $\begin{array}{l}.39 * * * \\
(.056)\end{array}$ & $\begin{array}{l}.37 * * * \\
(.055)\end{array}$ & $\begin{array}{c}.88 * * * \\
(.1)\end{array}$ & $\begin{array}{l}.0036 * * * \\
(.00094)\end{array}$ & $\begin{array}{l}.0036 * * * \\
(.00091)\end{array}$ & $\begin{array}{c}.015^{*} \\
(.0076)\end{array}$ & $\begin{array}{c}.015^{*} \\
(.0076)\end{array}$ \\
\hline
\end{tabular}

\begin{tabular}{lccccccc} 
Composition controls $^{\ddagger}$ & $\mathrm{N}$ & $\mathrm{Y}$ & - & $\mathrm{N}$ & $\mathrm{Y}$ & $\mathrm{N}$ & $\mathrm{Y}$ \\
School type controls $^{\dagger}$ & $\mathrm{Y}$ & $\mathrm{Y}$ & - & $\mathrm{Y}$ & $\mathrm{Y}$ & $\mathrm{Y}$ & $\mathrm{Y}$ \\
School Fixed Effects & $\mathrm{Y}$ & $\mathrm{Y}$ & - & $\mathrm{Y}$ & $\mathrm{Y}$ & $\mathrm{Y}$ & $\mathrm{Y}$ \\
Year Fixed Effects & $\mathrm{Y}$ & $\mathrm{Y}$ & - & $\mathrm{Y}$ & $\mathrm{Y}$ & $\mathrm{Y}$ & $\mathrm{Y}$ \\
& & & & & & & \\
$\mathrm{N}$ & 123053 & 123053 & 33049 & 123023 & 123023 & 123053 & 123053 \\
$R^{2}$ & .97 & .97 & - & .16 & .16 & .55 & .55 \\
\hline
\end{tabular}

Note: This table shows regression estimates (OLS) of the effect of private equity ownership on education inputs and operational outcomes. Observations are at the school (UnitID)-year level. ${ }^{*}$ Dependent variable is an indicator for a change in school CEO within first three years after buyout. ${ }^{ \pm}$Nearest-neighbor matching is done within the sample of other for-profit schools, where the dependent variable is measured the year after the treated school's buyout. Matching is exactly on the year before the treated school's buyout, and then on characteristics. ${ }^{\ddagger}$ We control for the share of students who are white, black, and Hispanic, and the average amount of federal Pell grants per student, a proxy for low-income students. ${ }^{\dagger}$ These are indicators for having selective admissions, public ownership, and are fixed effects for highest degree offered. The latter includes less than 2-year (certificate), 2-year, or 4-year. Standard errors two-way clustered by SystemID and year. Coefficients marked with $*, * *, * * *$, denote $\mathrm{p}<.1, \mathrm{p}<.05, \mathrm{p}<.01$, respectively. 
Figure 1: For Profit Schools Share of Loan Defaults and Enrollment
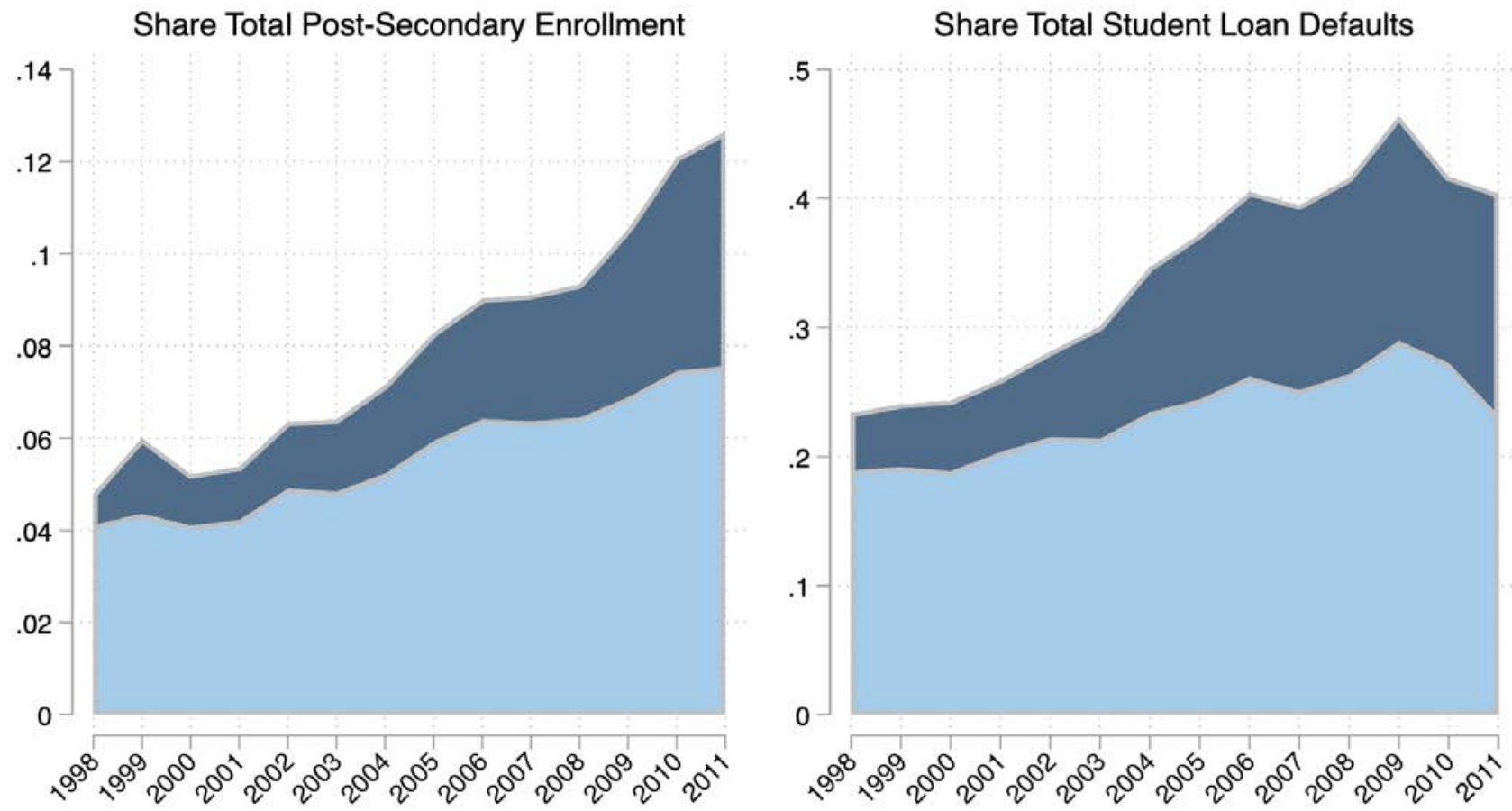

\section{PE-backed For Profits Other For Profits}

Note: The left graph shows the for-profit share of total U.S. postsecondary enrollment by whether a school was ever private equity-owned. The right graph shows the share of total student loan defaults within two years of entering repayment, by whether a school was ever private equity-owned. 
Figure 2: Employees in Sales and Non-Instructional Activities
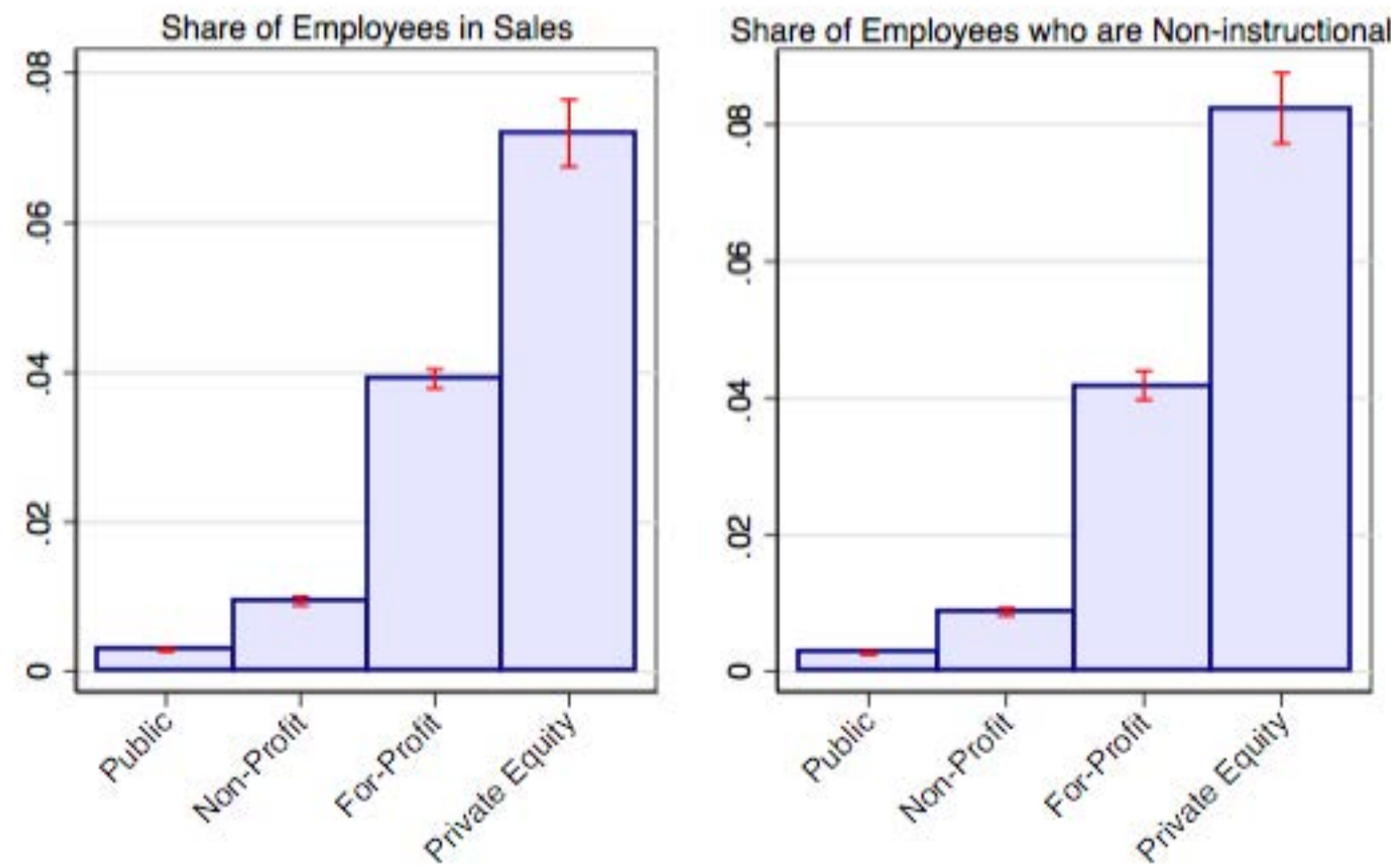

Note: The figure above shows the share of employees who do sales and non-instructional activities by institution type from 2012 to 2015 (data available only for these years). 
Figure 3: Per-student Tuition and Per-student Loan Event Studies
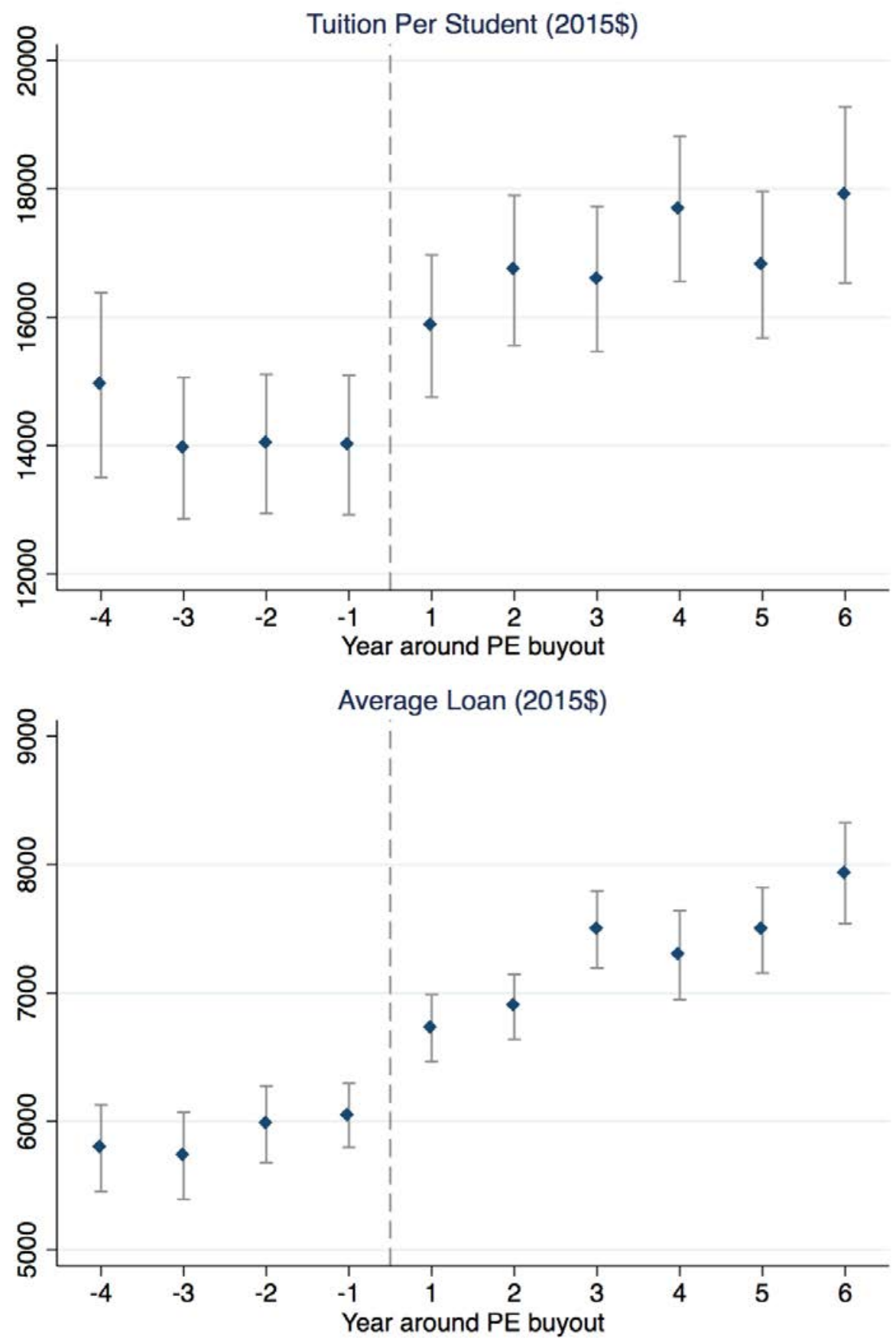

Note: The figures above show, within the sample of school systems bought by PE, the means of tuition per student and average loan per student in the years around the ownership change. The level of observation is the ultimate parent company, or SystemID level ( $\mathrm{N}=88$ in each year) for the average loan variable. It is at the school, or UnitID level for the tuition per student variable, for which we restrict the observations to schools that existed in the year prior to the buyout ( $\mathrm{N}=697)$. We restrict the observations to schools that existed in the year prior to the buyout. 95\% confidence intervals shown. 
Figure 4: Loan Limit Increase Diff-in-diff Coefficients over Time

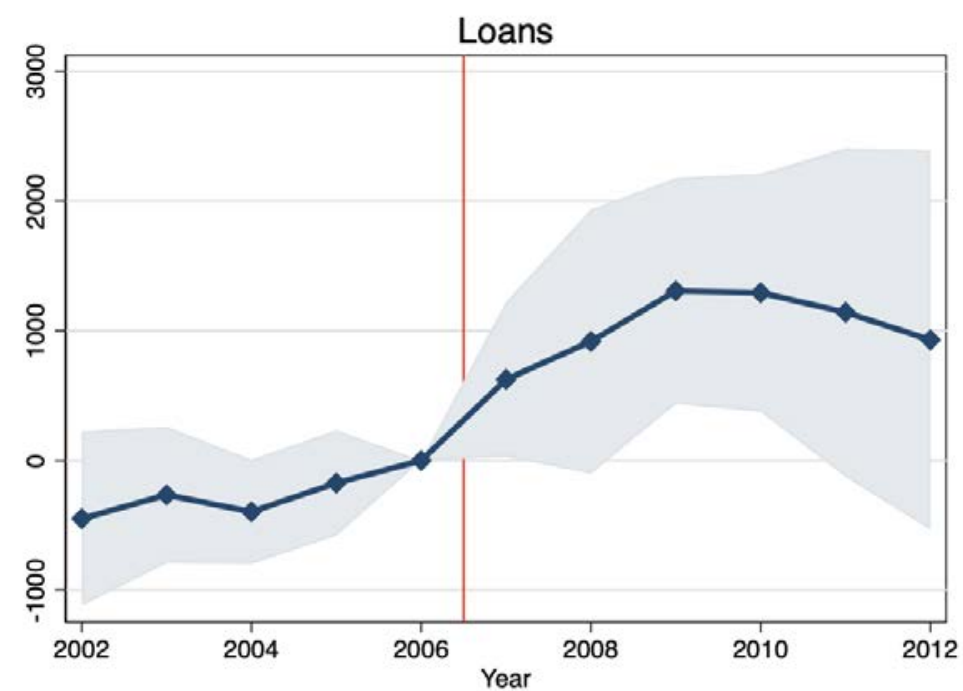

\section{Tuition}

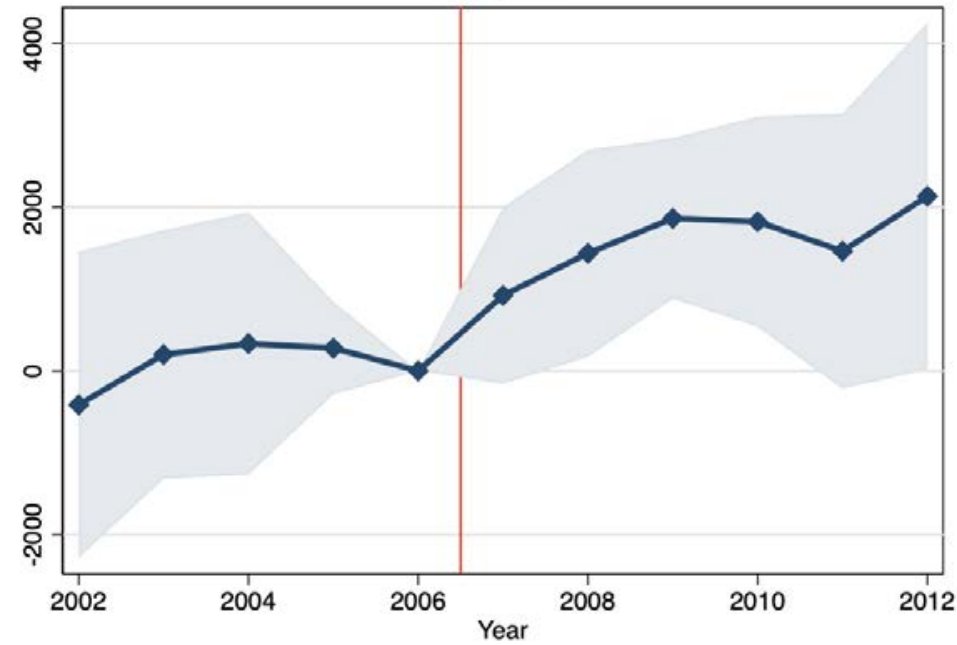

Note: The figure above shows coefficients $\beta_{j}$ from the following specification $L_{i t}=\alpha_{i}+\alpha_{t}+\sum_{j=2001}^{2015} \beta_{j} P E_{i} *$ $1[$ Year $=j]+\gamma X_{i t}+\varepsilon_{i t}$, where 2006 is the base year. The areas represent $95 \%$ confidence intervals. Results are enrollment weighted. The vertical line is positioned before 2007, when student borrowing limits were increased. Standard errors are clustered at the school system level. 
Figure 5: Graduation Rate and Repayment Rate Event Studies
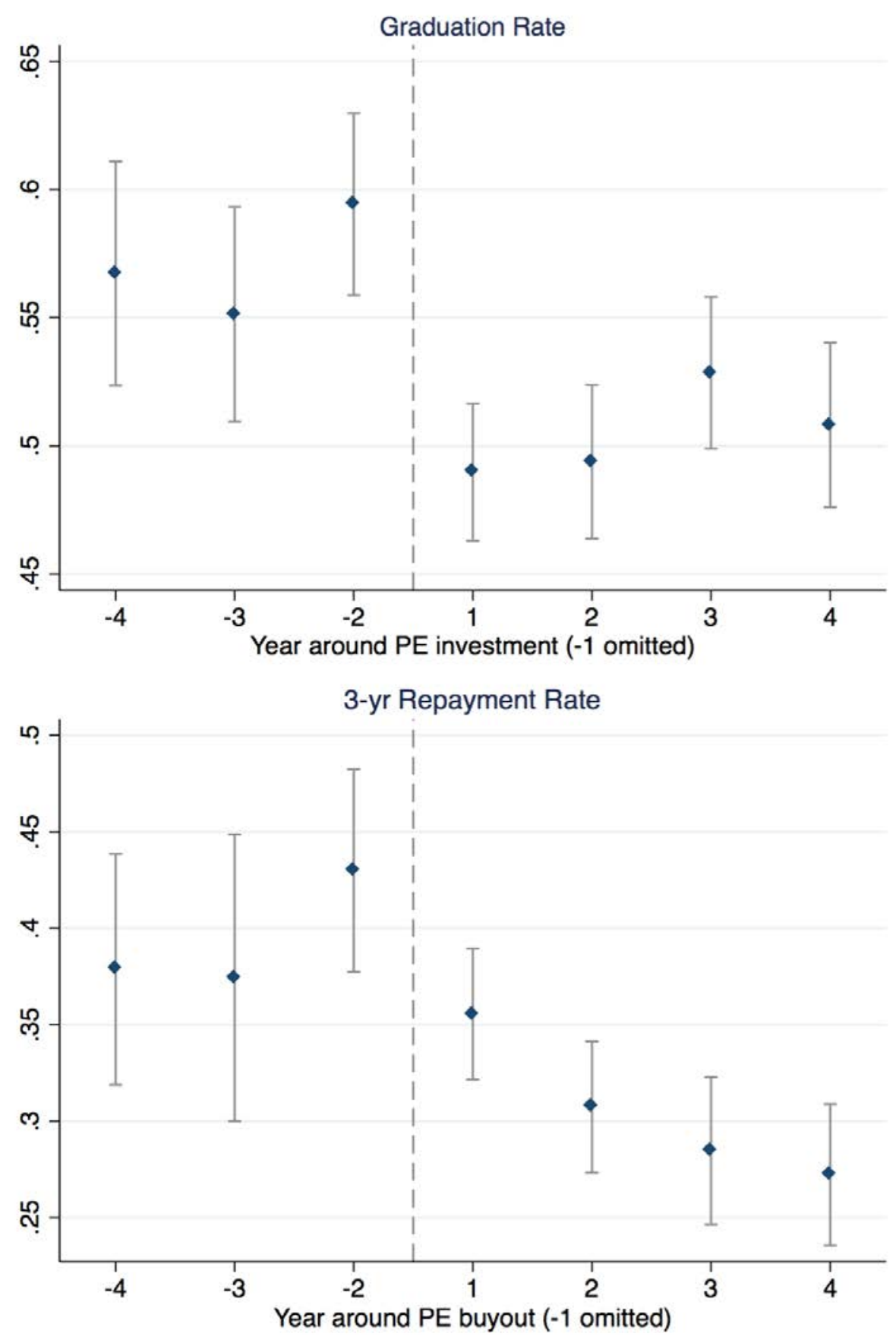

Note: The figures above show, within the sample of school systems bought by PE, the means of the graduation rate and the repayment rate in the years around the ownership change. The level of observation is the school, or UnitID level $(\mathrm{N}=697)$. We omit partially treated cohorts. For 4-year schools, this consists of the cohorts enrolled starting in the three years preceding the buyout year. For 2-year schools, this consists of the cohort enrolled the year before the buyout year. There are no observations for repayment rates in years -5 or 5 (there is generally less coverage in the data). $95 \%$ confidence intervals shown. 
When Investor Incentives and Consumer Interests Diverge:

Private Equity in Higher Education

\section{Online Appendix}

Charlie Eaton, Sabrina T. Howell \& Constantine Yannelis 


\section{Appendix A: Institutional Context}

This Appendix first briefly describes the history and defining characteristics of the for-profit higher education sector. Then, in Section 2, we provide evidence from existing literature that returns to for-profit education are likely worse - and definitely no better than - similarly selective public community colleges. We explain how the federal student loan and grant programs create misaligned incentives in Section 3. Finally, in Section 4, we discuss the role of private equity in for-profit higher education.

\section{A.1 History and defining features of for-profit higher education}

For-profit colleges are incentivized to target prospective students whose low incomes qualify them to pay tuition primarily with federal grants and loans. Schools receive federal grants and loans when the student enters school, and revenue is largely disconnected from graduation rates and labor market outcomes. The taxpayer bears the cost of student defaults. ${ }^{1}$ An absence of accessible information, the difficulty of assessing returns to education, and long lags between enrollment and job placement impede low product quality from translating into reduced future sales (Arcidiacono et al. 2016, Bettinger et al. 2012, Wiswall and Zafar 2014). Thus government aid and loan guarantees create a potential misalignment of incentives between for-profit school owners and customers.

Proprietary, or for-profit, schools have existed in the U.S since the early 1900s. For much of the 20th century, they offered primarily technical and business skills, such as typing. They were also mostly independent (i.e. single-unit businesses) and privately held. In 1981, for-profit enrollment was just 0.2 percent of total enrollment. Consolidation and increases in external equity financing

\footnotetext{
${ }^{1}$ Legislation proposed in the U.S. Congress in November, 2017 would require schools to repay a portion of defaulted student loans. A Wall Street Journal article noted that "This so called skin-in-the-game proposal has been long fought by the powerful higher education lobby." See https://www.wsj.com/articles/house-gop-to-proposesweeping-changes-to-higher-education-1511956800.
} 
began in the 1980s, with substantial private equity involvement. Substantial growth accompanied these changes; between 1990 and 1995, for-profit enrollment was between 0.35 and 0.82 million, or 2-5 percent of total enrollment. The largest for-profits today are publicly traded, and all had private equity investment at one time (see Table C.1). The sector has continued to grow. Between 2010 and 2016, annual total enrollment at for-profit schools has been between 1.5 and 2.7 million students, or between 8 percent and 11 percent of total enrollment in all higher education.

While the sector is heterogenous, compared to their nonprofit and public counterparts, forprofits have smaller and leaner physical plants, have far more students in online learning programs, have few non-instructional services like athletics, typically have no research activities, hire most faculty on short-term contracts, and spend more on career counseling (Lang and Weinstein 2013). ${ }^{2}$ In lieu of large humanities programs, for-profits focus on teaching specific, often vocational, skills designed to meet specific job descriptions, such as hair stylist or IT specialist. To minimize costs, successful for-profits typically offer structured, focused programs of study with few electives. The material is standardized and replicated across a company's campuses and online programs. This approach has been quite successful; chains and online institutions were responsible for almost 90 percent of the growth of the for-profit sector in the 2000s (Deming, Goldin, and Katz 2012).

Resources are focused on sales and marketing. Deming et al. (2012) cite evidence that at large national for-profit chains, sales and marketing expenditure comprised 24 percent of revenue in 2009 , making the average cost of acquiring a new customer $\$ 4,000$. In contrast, sales and marketing comprises about 10 of revenue in healthcare, and 8 percent in financial services. ${ }^{3} \mathrm{~A}$ U.S. Senate staff report found that in 2010, 30 representative for-profit schools employed about one recruiter for every 53 students, ten times the number of career services staff and 2.5 times the number of support services staff (Senate 2012). Recruiters' compensation was closely tied to new enrollments. The report found that public for-profits spend 23 percent of their revenue on

\footnotetext{
${ }^{2}$ While the sector is dominated by a few large chains, such as the University of Phoenix, there are many small schools providing niche vocational certificates for jobs such as dog grooming (Deming et al., 2012). Just over half of the degrees awarded by for-profits are certificates, but for-profits offer undergraduate, doctorate, and many other degrees.

${ }^{3}$ See http://deloitte.wsj.com/cmo/2017/01/24/who-has-the-biggest-marketing-budgets/
} 
marketing and recruiting, and cited evidence of large-scale student deception about completion rates, placement rates, and other statistics. The report concluded that the lack of student support "may help to explain why more than half a million students who enrolled in 2008-9 left without a degree or Certificate by mid-2010.” A 2010 GAO investigation sent undercover agents to apply to for-profits. They found deceptive marketing at all targeted schools, and applicants "were encouraged by college personnel to falsify their financial aid forms to qualify for federal aid" at 26 percent of schools. ${ }^{4}$

The student body at for-profit schools is quite different than that at other schools, even the closest comparison, public community colleges. Deming, Goldin, and Katz (2012) compare forprofit schools to community colleges, public, and nonprofit institutions. They note that on average, students at for-profits come from lower-income families and are more likely to be single parents than students in community colleges (two-year public schools). Other evidence that students at forprofit schools are disproportionately less well-prepared, and more likely to be ethnic minorities, is in Chung (2012). Similarly, Looney and Yannelis (2015) show that for-profit borrowers tend to be poorer, older, and have worse labor post-school market outcomes. ${ }^{5}$

The 2000s saw a dramatic increase in student loan volumes and defaults. After 2008, high rates of student defaults and the new political environment led to increased scrutiny and regulatory oversight of for-profit colleges. Enrollment growth slowed, and the large chains saw substantial declines in new student volumes. The Obama Administration sought to implement tighter controls over eligibility for federal student aid, and together with local law enforcement, began to aggressively pursue for-profit higher education companies for various types of fraud.

\footnotetext{
${ }^{4}$ https://www.gao.gov/products/GAO-10-948T

${ }^{5}$ For example, among dependent borrowers, median family income of students at for-profit schools was $\$ 30,000$, compared to $\$ 48,000$ at 2-year and nonselective 4-year schools. In 2011, only 37 percent of borrowers at for-profit schools were dependents, compared to 50 percent (70 percent) at 2-year (nonselective 4-year) institutions. Deming et al. (2012) find that for-profits leave students with higher unemployment, lower earnings, and higher loan default rates than comparable students who graduated from other types of schools. Looney and Yannelis (2015) find that for the cohort of students that left school in 2011, over 20 percent were unemployed two years later, and median earnings were about $\$ 20,000$. The former is higher, and the latter is lower, than for any other institution type, and furthermore increased (decreased) more relative to 2000 than for any other institution type. The five-year cohort default rate in 2011 was 47 percent, compared to 38 percent (27 percent) at 2-year (nonselective 4-year) institutions.
} 


\section{A.2 Returns to For-Profit Education}

Significant information and market frictions exist in the higher education sector (Bettinger et al. (2012); Wiswall and Zafar (2014)). Also, students targeted by for-profits are among the most stressed and disadvantaged portions of the population, making them more prone to manipulative advertising than other groups; 29 percent are single parents, compared to 12 percent at community colleges, and their family income is about half that of students at community colleges (Deming, Goldin, and Katz 2012, Schilbach, Schofield, and Mullainathan 2016). Despite these differences, Cellini, Darolia, and Turner (2017) show that community colleges, which have open enrollment (i.e. are not selective or capacity constrained), are substitutes to for-profit schools. These public institutions devote far fewer resources to advertising as is shown in the main text, and thus do not compete in a meaningful way for students.

There is accumulating causal evidence that relative to their substitutes - public community colleges - the returns to for-profit education are zero or negative. Deming et al. (2016) assess employer perceptions of higher education institutions using an experiment in which they sent resumes with different types of degrees to job openings. They found that applicants with business BAs from large online for-profit schools were roughly 22 percent less likely to be contacted than the same applicants with similar degrees from nonselective public schools. Within health jobs, this discrepancy was 57 percent. Having a for-profit associates degree made a person no more likely to be contacted than the same resume with no postsecondary degree at all. Deming et al. (2016) conclude that "employers appear to view for-profit postsecondary credentials as a negative signal of applicant quality, particularly when objective measures of quality such as a licensing exam are unavailable." In a similar experiment in which resumes were randomly sent to employers, Darolia et al. (2015) found that employers did not prefer applicants with a for-profit degree to those with no college at all. Further, they found that employers seemed to slightly prefer (albeit not significantly) applicants with public community college degrees over those with comparable for-profit degrees.

Using administrative data from the National Student Clearinghouse between 2000 and 2012, 
Liu and Belfield (2014) find large wage penalties when community college students transfer to a for-profit college rather than a nonprofit college. They use transcript and other data to control for selection into for-profits. Cellini and Chaudhary (2014) use data from the NLSY97 to show that for-profit graduates are not more likely to be employed than comparable people with only high school degrees; though they find a positive effect on earnings (of about 4 percent per year), this is contingent on program completion, which many enrollees do not accomplish. The upper bound on their findings are substantially lower than the returns that other studies have calculated to public community colleges (e.g. Jacobson et al. 2005, Jepsen et al. 2014). ${ }^{6}$

Cellini and Turner (2016) address the selection problem by examining within-student wages before and after attending college, using administrative data on about 1.4 million students. They find that despite much higher tuition, for-profit students experience smaller earnings increases than students at comparable public community colleges. The vast majority of for-profit students experience both lower earnings and higher debt after college than they did before college. Finally, Armona et al. (2017) assess the effect of attending a for-profit college relative to a local public college or university using an instrumental variables strategy. They combine local labor market shocks with local school supply to instrument for enrollment in a for-profit relative to a community college. They find that students at for-profits are less likely to be employed, have lower earnings, and have higher debt and higher default rates than students at public counterparts.

\section{A.3 Federal Student Loans and Grants}

For-profit higher education companies depend heavily on federal student loans and grants; the largest chains get over 80 percent of their revenue from federal sources. This fraction would be even higher if it were not for the 90-10 rules, and a statutory limit that 90 percent of revenue can come from Title IV loan and grant programs, which exclude veteran and military benefits.

\footnotetext{
${ }^{6}$ In contrast to the above studies, Lang and Weinstein (2013) find no difference in returns to certificate programs across for-profits and non-profits. They compare labor market outcomes for completers and non-completers across institution types, arguing that if this difference is similar, lower earnings for for-profit graduates are likely explained by the more disadvantaged student body at for-profit schools.
} 
When these sources are included, many for-profits exceed the 90 percent threshold (Kelchen 2017). Maintaining Title IV eligibility is crucial for most higher education institutions, and it requires maintaining accreditation with one of a number of private accrediting agencies, and meeting certain standards, notably limits on the share of students that default over a three-year period.

Federal student loan programs were established in the 1960s and 1970s, and were targeted to upper middle class students attending higher tuition private colleges (Shireman, 2017). Government budget rules made it difficult for the federal government to lend directly to students without having to report the loans as adding to the deficit. Congress therefore subsidized the provision of federal loans by private lenders by legislating that the U.S. Department of Education would provide guarantees to private lenders (Berman and Stivers, 2016). That is, the federal government would cover bank losses when students fail to repay loans. The federal government also created the Student Loan Marketing Association, commonly known as Sallie Mae, in 1973. Sallie Mae raised capital to buy and offer student loans by securitizing loans and selling those securities to investors.

The banking industry aggressively lobbied for the expansion of the guaranteed student loan program during the 1980s (Wilson 1987, Berman and Stivers 2016, Shireman, 2017). This was accomplished in 1991, when unsubsidized Stafford loans were introduced. These were unsubsidized because the federal government would not pay interest accrued while the borrower was in school, but would guarantee against non-repayment. The limit for total borrowing with both subsidized and unsubsidized Stafford loans doubled from about $\$ 30,000$ to over $\$ 70,000$ (in 2015 dollars $)^{7}$

The Federal Credit Reform Act of 1990 had changed federal accounting rule and made it possible for the federal government to directly lend to students at a much lower cost (Berman and Stivers 2016). However, the government opted to maintain the more costly guarantee subsidies from the federal government to private lenders, so that Sallie Mae and commercial banks would receive support to provide most of the expanded federal student loan programs.

\footnotetext{
${ }^{7}$ See Financial Aid for more information.
} 
Private lenders and for-profit colleges receiving the loans now had direct incentives to promote the expansion of student borrowing. This was achieved though regular increases in borrowing caps, higher interest rates, and restrictions on borrowers' ability to discharge debt in bankruptcy. The result was a large increase in federally guaranteed student debt disbursements from about \$20 billion per year during the 1980 s to $\$ 120$ billion at the peak in 2011 . Per student annual borrowing flows increased more than three-fold from a little less than $\$ 2,000$ per student in the 1980 s to over $\$ 7,000$ in 2011.8

Looney and Yannelis (2015) find evidence that the massive increases in student loan defaults between 2000 and 2011 was concentrated in for-profit schools, and arose in part because of their growth. Federal loans to undergraduate borrowers at for-profit schools increased from $\$ 3.6$ billion in 2000 to $\$ 18$ billion in 2011. Borrowers entering repayment at for-profit schools increased from just over 200,000 individuals in 2000 to about 900,000 in 2011.

Today, Title IV programs consist of Stafford loans, Perkins loans, PLUS loans for parents, Pell Grants, and work study programs. The amount of federal aid a student may receive depends on family-specific factors as well as the cost of attendance, of which the most important element is tuition. Cellini and Goldin (2014) point out that this creates an incentive for for-profit schools to increase tuition above cost. They evaluate whether for-profits increase tuition in response to increases in federal loan subsidies, and find some evidence for federal aid capture. Using administrative data from California between 1989 and 2003, Cellini (2010) finds that increases in federal and state grants and loans is strongly correlated with for-profit school entry, particularly in high poverty counties. ${ }^{9}$

Pell Grants are need-based awards that depend on a student's family income, the cost of school attendance, and the length and type of program. ${ }^{10}$ The average Pell grant is about $\$ 3,724$ per year,

\footnotetext{
${ }^{8}$ Per full time enrolled student. Available at the College Board.

${ }^{9}$ In the aftermath of the 2008 financial crisis, Sallie Mae and the major consumer banks found themselves unable to raise adequate capital from securities markets to fund federal student loans. The Obama administration responded by eliminating the provision of federal student loans through private lenders. Instead, the Department of Education would provide loans directly to students. It used savings from this change to fund a significant expansion of Pell Grants (Shireman, 2017).

${ }^{10}$ The Department of Education has more information on the Pell grant program.
} 
and the maximum is $\$ 5,775 .{ }^{11}$ In $2008-09$, for-profits enrolled 12 percent of students but accounted for 24 percent of Pell grant disbursement, and 26 percent of federal student loan disbursements (Deming et al. 2012).

\section{A.4 Private Equity in Higher Education}

A private equity buyout usually affects the target firm's finances, its operations, or both. The key financial innovation of the typical leveraged buyout is to pay for much of the acquisition with debt issued by the target firm. Beyond changing in the target's capital structure, private equity firms also impose transaction and monitoring fees on the target. Metrick and Yasuda (2010) find that that these fees can represent as much as 90 percent of compensation to the private equity firm, suggesting that they could be material costs to the target firm. They are, however, difficult to observe (Metrick and Yasuda 2011). In operations, Bloom et al. (2015) directly measure management practices and find that private equity owned firms have better management, equaled only by public firms and family firms run by external CEOs. In manufacturing, Davis et al. (2014) find that private equity owned firms expand productive plants and shutter underperforming ones. Bernstein and Sheen (2016) also find evidence of better operations in private equity owned restaurants, in part through better worker training and incentive alignment.

Private equity investments in higher education have generally taken one of two forms. One is the purchase of independent (small, private) colleges, usually with consolidation intent. The second is the large buyout of an existing chain institution; the biggest have taken public companies private. For example, in $2007 \mathrm{KKR}$ and SAC Capital took Laureate Education private for $\$ 3.8$ billion. ${ }^{12}$ An example of the first type of investment, and which illustrates the broader pattern we find in the data, is TA Associates' buyout of Florida Career College for $\$ 53$ million in 2004. At the time, Florida

\footnotetext{
${ }^{11}$ See theCollege Board for more information.

${ }^{12}$ For other evidence on publicly traded and privately owned schools, see Eaton et al. (2016). Other examples include Goldman Sachs taking Education Management Corp (EDMC) private in 2006 for \$3.4 billion, and various investors, including Vistria Group, taking Apollo Education Group (University of Phoenix) private in 2017 for $\$ 1.1$ billion.
} 
Career College had four campuses and 2,500 students. After adding three additional campuses and expanding enrollment to 4,000 students, TA Associates sold its stake in 2007 for \$192 million, almost quadrupling its investment. Later in 2007, federal investigators found employees producing fraudulent high school diplomas for applicants, and encouraging students to lie about their high school status. ${ }^{13}$

Florida Career also illustrates how private equity pressures for rapid growth in operating margins can lead to declines in graduation rates. After TA Associates exited, Florida Career Colleges along with Midwest Career Colleges was acquired by Greenhill Capital Partners and Abrams Capital. Initially, the company took steps to address compliance issues. In an email interview with the authors, however, a high-level manager said: "When presenting annual results to investors, I told Managing Partner of PE firm [sic] that I wanted to address all the compliance and regulatory achievements. He laughed and said 'they don't care about that. All they want to know is how much money you made them."' In this context, investors again changed the senior management of Florida and Midwest Career in 2012. After these changes in executive leadership, "they started decimating faculty and student services and opening doors to all students regardless of ability" according to the former high-level manager.

Similar changes occurred after private equity buyouts of existing chains such as the KKR acquisition of Laureate. A 3,000 page investigative report by the U.S. Senate Health, Labor, Education, and Pension Committee in 2012 examined complaint data from most of 10 firms for which it published case studies on firm behavior after buyouts. Student complaints consistently point to a heavy reliance on part-time instructors with minimal certification and high instructional staff turnover rates. After the buyout of Concorde Career Colleges by Liberty Partners in 2006, for example, the entire 2010 class of licensed vocational nursing students at one campus filed a complaint with administrators. In their complaint, the students wrote that: "instructors [were] late to start class ... [by] 20-40 minutes," lectures were "vague" and "lack[ed] structure," instructors were "ill prepared" and spent time "searching for lost papers or tests or equipment" (Senate,

\footnotetext{
${ }^{13}$ See the Chronicle for further information.
} 
$2012,374)$

A student in a separate March 11, 2010 complaint letter complained that the Concorde's San Bernardino campus had cycled through three Directors of Nursing and two Assistant Directors during the student's first year at the school. Annual faculty turnover across all Concorde campuses was 42 percent in 2008 and 35 percent in the first 9 months of 2009 (Senate, 2012, 374).

With backing from Warburg Pincus, Bridgepoint Education made similar changes after acquiring Ashford University and University of the Rockies. Bridgepoint transformed its schools into exclusively online campuses with 96 percent of faculty working only part-time (Senate, 2012, 310). With 39 percent of its expenditures going to marketing and recruitment, enrollment at Bridgepoint grew to a high of 77,119 students in 2010 (Senate, 2012, 299). Deceptive recruiting practices at Bridgepoint may have in turn harmed graduation rates, after-school earnings, and student debt repayment. Brent Park, a former recruiter for Bridgepoint submitted written testimony to a Department of Education rulemaking process in which he wrote: "If we don't have a degree they want, we are supposed to convince them that one of ours will work for them anyway" (Senate, 2012, 305).Consistent with Park's account of Bridgepoint recruitment practices, four students submitted complaints that they were deceived about financial aid and whether the program in which they enrolled would actually provide adequate certification for teaching or dental licenses (Senate, 2012, 306).

Private equity has played a role in a large fraction of for-profit higher education by enrollment. Since the late 1990s, private equity-owned schools have contributed to a large portion of the growth in enrollment. Private equity owned schools have also contributed significantly to the increase in defaults. In the late 2000 s, despite being only approximately 10 percent of enrollments, for-profits schools accounting approximately 40 percent of student loan defaults. Most of this increase is attributable to the growth in the default share at private equity backed for-profits. The share of defaults has remained relatively flat at non private equity backed for-profit schools.

Education-related deals comprise between 2 and 3 percent of total private equity deal volume and number (Appendix Figure B.1). However, other sectors with similar issues of incentive 
alignment are remarkably large shares of the industry. Appendix Figure B.1 shows that healthcare, infrastructure, and defense have at different times comprised significant shares of total private equity deals. For example, since 2010, health-related deals have comprised about 40 percent of total private equity deal value and volume, and infrastructure has comprised about 14 percent of deal value, and 23 percent of deal volume. These sectors also feature intensive government subsidy, opaque outcomes that are distant in time from payment for service, and diffuse customers who may not have the ability to "vote with their feet".

Private equity ownership may increase profitability through operational changes, or may yield returns to investors through financial engineering. We do not observe debt, and are in any event interested in student outcomes, so we focus on operations. Profit growth in higher education, as in many industries, comes from increasing scale (enrolling more students) and increasing margins (the gap between costs and revenues). This differs markedly from most nonprofit higher education institutions, which are primarily concerned with increasing prestige and attracting those students most likely to succeed in labor markets (Hentschke 2010). It also differs from public institutions, which are typically capacity constrained by state and local funding limits (Hentschke 2010). 
Appendix B: Additional Tables and Figures

Online Appendix 
Table B.1: Variable Descriptions

\begin{tabular}{|c|c|c|c|c|}
\hline Variable name & $\begin{array}{c}\text { Unit of } \\
\text { Analysis }\end{array}$ & $\begin{array}{c}\text { Years } \\
\text { covered }\end{array}$ & Source & Description \\
\hline \multicolumn{5}{|c|}{ Panel 1: School Type } \\
\hline Highest degree offered & UnitID & $\begin{array}{l}1987- \\
2015\end{array}$ & IPEDS & $\begin{array}{l}\text { Indicator for whether the highest degree offered } \\
\text { is a 4-year degree or higher, a 2-year degree, or a } \\
\text { less-than-2-year certificate or degree. }\end{array}$ \\
\hline Selective admissions & UnitID & $\begin{array}{l}1987- \\
2015\end{array}$ & IPEDS & $\begin{array}{l}\text { An indicator for whether the school has any } \\
\text { selective admissions requirements. }\end{array}$ \\
\hline \multicolumn{5}{|c|}{ Panel 2: Demographics } \\
\hline Share students white & UnitID & $\begin{array}{l}1987- \\
2015\end{array}$ & IPEDS & $\begin{array}{l}\text { Share of fall semester undergraduates who are } \\
\text { white. }\end{array}$ \\
\hline $\begin{array}{l}\text { Total Pell grant revenue per } \\
\text { student (mill 2015\$) }\end{array}$ & UnitID & $\begin{array}{l}1987- \\
2015\end{array}$ & IPEDS & $\begin{array}{l}\text { Total revenue from Pell grants awarded to } \\
\text { fulltime first-year students per fulltime first-year } \\
\text { student. }\end{array}$ \\
\hline \multicolumn{5}{|c|}{ Panel 3: Student Outcomes } \\
\hline Graduation rate, all levels & UnitID & $\begin{array}{l}1995- \\
2010\end{array}$ & IPEDS & $\begin{array}{l}\text { The graduation rate after } 150 \text { percent of normal } \\
\text { time to degree. }{ }^{ \pm \pm}\end{array}$ \\
\hline Cohort default rate (2 year) & OPEID & $\begin{array}{l}1990- \\
2011\end{array}$ & NSLDS & $\begin{array}{l}\text { The default rate of the exiting cohort of } \\
\text { borrowers } 2 \text { years after the cohort leaves school } \\
\text { by either graduating or dropping out. }\end{array}$ \\
\hline $\begin{array}{l}\text { Loan repayment rate }(3 \\
\text { year) }\end{array}$ & OPEID & $\begin{array}{l}2007- \\
2011\end{array}$ & NSLDS & $\begin{array}{l}\text { The share of borrowers who have not defaulted } \\
\text { and have repaid at least } \$ 1 \text { dollar of principal on } \\
\text { their loans } 3 \text { years after exiting school either by } \\
\text { graduating or dropping out. }\end{array}$ \\
\hline $\begin{array}{l}\text { Wages } 6 \text { years after } \\
\text { graduation }\end{array}$ & OPEID & $\begin{array}{l}1998- \\
2007\end{array}$ & $\begin{array}{l}\text { College } \\
\text { Score } \\
\text { Card }\end{array}$ & $\begin{array}{l}\text { Average income of exiting student cohort } 6 \text { years } \\
\text { after the cohort leaves school by either graduating } \\
\text { or dropping out. }\end{array}$ \\
\hline \multicolumn{5}{|c|}{ Panel 4: Operational Outcomes } \\
\hline Share of employees in sales & UnitID & $\begin{array}{l}2012- \\
2015\end{array}$ & IPEDS & The share of school employees who are in sales. \\
\hline $\begin{array}{l}\text { Non-instructional share of } \\
\text { employees. }\end{array}$ & UnitID & $\begin{array}{l}2012- \\
2015\end{array}$ & IPEDS & $\begin{array}{l}\text { The share of school employees who are not } \\
\text { instructional. }\end{array}$ \\
\hline Number of students & UnitID & $\begin{array}{l}1987- \\
2015\end{array}$ & IPEDS & $\begin{array}{l}\text { The number of fall semester fulltime equivalent } \\
\text { students.* }\end{array}$ \\
\hline Online institution & UnitID & $\begin{array}{l}1987- \\
2015\end{array}$ & IPEDS & $\begin{array}{l}\text { Indicator for whether a school was an online } \\
\text { campus. }{ }^{ \pm}\end{array}$ \\
\hline 1st law enforcement action & UnitID & $\begin{array}{l}1987- \\
2015\end{array}$ & Authors & $\begin{array}{l}\text { Indicator for the school experiencing its first law } \\
\text { enforcement action in year. }\end{array}$ \\
\hline
\end{tabular}




\section{Panel 5: Financial Outcomes}

\begin{tabular}{|c|c|c|c|c|}
\hline Profits & UnitID & $\begin{array}{l}1987- \\
2015\end{array}$ & IPEDS & $\begin{array}{l}\text { Gross operarting margins calculated as total } \\
\text { revenue minus total education and operating } \\
\text { costs. }\end{array}$ \\
\hline $\begin{array}{l}\text { Net tuition revenue per FTE } \\
\text { Student }(2015 \$)\end{array}$ & UnitID & $\begin{array}{l}1987- \\
2015\end{array}$ & IPEDS & $\begin{array}{l}\text { Total revenue from tuition, including tuition paid } \\
\text { for by federal and state grant aid programs, } \\
\text { divided by the number of FTE students }\end{array}$ \\
\hline $\begin{array}{l}\text { Average loan per borrower } \\
(2015 \$)\end{array}$ & UnitID & $\begin{array}{l}2000- \\
2015\end{array}$ & IPEDS & $\begin{array}{l}\text { Dollars borrowed per borrower among fulltime, } \\
\text { first-year undergraduate student. }\end{array}$ \\
\hline $\begin{array}{l}\text { Federal grant revenue per } \\
\text { student (mill 2015\$) }\end{array}$ & UnitID & $\begin{array}{l}2000- \\
2015\end{array}$ & IPEDS & $\begin{array}{l}\text { Total revenue from federal grants awarded to } \\
\text { fulltime first-year students per fulltime first-year } \\
\text { student. }\end{array}$ \\
\hline
\end{tabular}

\begin{tabular}{|c|c|c|c|c|}
\hline \multicolumn{5}{|c|}{ Panel 6: Educational Inputs } \\
\hline Faculty per 100 students & UnitID & $\begin{array}{l}1987- \\
2015\end{array}$ & IPEDS & The number of fulltime faculty per 100 students. \\
\hline Instruction spending share & UnitID & $\begin{array}{l}1987- \\
2015\end{array}$ & IPEDS & $\begin{array}{l}\text { The share of all expenditures related to } \\
\text { instruction. }\end{array}$ \\
\hline \multicolumn{5}{|c|}{ Panel 6: Ownership and identifiers } \\
\hline $\mathrm{PE}$ & & $\begin{array}{l}1987- \\
2015\end{array}$ & Authors & $\begin{array}{l}\text { Indicator for whether a parent company of a } \\
\text { college or system was under private equity } \\
\text { ownership at the beginning of the academic year. }\end{array}$ \\
\hline Public & & $\begin{array}{l}1987- \\
2015\end{array}$ & Authors & $\begin{array}{l}\text { Indicator for whether a parent company of a } \\
\text { college or system was publicly traded at the } \\
\text { beginning of the academic year.** }\end{array}$ \\
\hline UnitID & & $\begin{array}{l}1987- \\
2015\end{array}$ & IPEDS & $\begin{array}{l}\text { Unique identification number assigned to } \\
\text { postsecondary institutions surveyed in IPEDS. }\end{array}$ \\
\hline SystemID & & $\begin{array}{l}1987- \\
2015\end{array}$ & Authors & $\begin{array}{l}\text { A unique identifier created by the authors for the } \\
\text { parent system of postsecondary institutions } \\
\text { including parent companies of for-profit college } \\
\text { chains. }\end{array}$ \\
\hline OPEID & & $\begin{array}{l}1990- \\
2015\end{array}$ & NSLDS & $\begin{array}{l}\text { Reporting unit in the National Student Loan Data } \\
\text { System. }{ }^{\dagger \dagger}\end{array}$ \\
\hline Year & & $\begin{array}{l}1987- \\
2015\end{array}$ & IPEDS & $\begin{array}{l}\text { Year in which the spring term ends. For example, } \\
\text { the } 2001 / 2002 \text { academic year is referred to as } \\
2002 \text {. }\end{array}$ \\
\hline
\end{tabular}

Note: ${ }^{*}$ Each part time student is included in this count as a fraction of a full time based on IPEDS specificied formulas. ${ }^{ \pm}$For-profit institutions are classified as online if they have the word online in their name or if they enroll no more than 33 percent of their students from a single state. This replicates the definition for online institutions used in Deming, Goldin, and Katz (2012). ${ }^{ \pm \pm}$For 4-year, 2-year, and less-than-2-year degrees and certificates. We include this by year of the cohort's first enrollment. ${ }^{* *}$ This is not mutually exclusive from private equity ownership such as in cases where private equity owners take a company public or acquire substantial shares in a publicly traded company without taking it private. ${ }^{\dagger \dagger}$ OPEIDs commonly encompass more than one college owned by a for-profit parent company.

\section{Online Appendix}




\section{Table B.2: Law Enforcement Actions}

Total law enforcement actions linked to IPEDS data

\section{Allegation}

Violated rules about recruiting/marketing*

Student loan fraud

False Claims

Misrepresented job placement statistics

Misrepresented credentials/accreditation

Embezzlement

Fraudulent High School Diplomas

Illegal Funds

Real estate fraud

Total school-year observations

Number of instances in which school experienced its first law enforcement action in years for which it reported enrollments to IPEDS
125

\section{Prosecuting Agency}

State AG $\quad 56$

DOJ 24

31 DOE 23

28 FBI 5

23 FTC 4

7 SEC 4

5 CFPB 3

4 Other 6

1

PE-owned Not PE-owned Total

$\begin{array}{lll}11,508 & 198,797 & 210,305\end{array}$

32

26

58

Note: This table documents the law enforcement actions. ${ }^{*}$ For example, there are regulations limiting incentive compensation to sales force. 
Table B.3: Nearest-neighbor matching covariate balance

\begin{tabular}{|c|c|c|c|c|c|c|c|c|}
\hline \multicolumn{9}{|c|}{ Panel 1: Balance after matching } \\
\hline & \multicolumn{3}{|c|}{ Control } & \multicolumn{3}{|c|}{ Treated } & \multirow[b]{2}{*}{ Diff } & \multirow[b]{2}{*}{$\begin{array}{l}\text { 2-tailed } \\
\text { p-value }\end{array}$} \\
\hline & $\mathrm{N}$ & Mean & S.d. & $\mathrm{N}$ & Mean & S.d. & & \\
\hline Community colleges in $\mathrm{CZ}$ & 52 & 8.67 & 10.21 & 4623 & 6.23 & 7.31 & 2.44 & 0.02 \\
\hline Independent for-profits in $\mathrm{CZ}$ & 52 & 17.27 & 22.40 & 4623 & 15.30 & 17.62 & 1.97 & 0.43 \\
\hline Log profits & 52 & 14.17 & 1.48 & 4623 & 14.00 & 1.44 & 0.17 & 0.39 \\
\hline Log FTE students in CZ & 52 & 6.33 & 1.48 & 4623 & 6.31 & 1.15 & 0.02 & 0.88 \\
\hline Share students white & 52 & 0.46 & 0.27 & 4623 & 0.59 & 0.26 & -0.14 & 0.00 \\
\hline IC Level & 52 & 2.17 & 0.65 & 4623 & 1.98 & 0.71 & 0.19 & 0.05 \\
\hline \multicolumn{9}{|c|}{ Panel 2: Balance before matching } \\
\hline & \multicolumn{3}{|c|}{ Control } & \multicolumn{3}{|c|}{ Treated } & & \\
\hline & $\mathrm{N}$ & Mean & S.d. & $\mathrm{N}$ & Mean & S.d. & Diff & $\begin{array}{l}\text { 2-tailed } \\
\text { p-value }\end{array}$ \\
\hline Community colleges in $\mathrm{CZ}$ & 45781 & 9.71 & 12.87 & 574 & 11.98 & 14.17 & -2.27 & 0.00 \\
\hline Independent for-profits in $\mathrm{CZ}$ & 45781 & 30.76 & 45.86 & 574 & 35.95 & 47.76 & -5.19 & 0.01 \\
\hline Log profits & 40440 & 14.19 & 2.30 & 508 & 14.31 & 1.72 & -0.12 & 0.25 \\
\hline Log FTE students in CZ & 42428 & 0.54 & 0.33 & 513 & 0.51 & 0.29 & 0.03 & 0.06 \\
\hline Share students white & 45774 & 6.38 & 1.48 & 573 & 6.75 & 1.21 & -0.37 & 0.00 \\
\hline IC Level & 45794 & 2.36 & 0.71 & 574 & 2.15 & 0.77 & 0.21 & 0.00 \\
\hline
\end{tabular}

Note: This table reports covariate balance after nearest-neighbor matching, using the matching for log FTE students. The sample is limited to for-profit, non-publicly traded schools. Further, among PE targets, the sample is limited to the year prior to the buyout. $\mathrm{CZ}$ refers to commuting zone. 
Table B.4: Effect of 2007 Loan Limit Increase on Faculty by PE status

Dependent Variable: FT Faculty per 100 Students

(1) (2) (3)

PE owned·Post $2007 \quad-1.4 * \quad-.61 * * * \quad-1$

$[.73] \quad[.15] \quad[.95]$

Controls $\quad \mathrm{N} \quad \mathrm{Y} \quad \mathrm{Y}$

Sample All All $\quad$ For-Profits

$\begin{array}{llll}\text { School Fixed Effects } & \text { Y } & \text { Y } & \text { Y }\end{array}$

$\begin{array}{llll}\text { Year Fixed Effects } & Y & Y & Y\end{array}$

$\begin{array}{llll}\text { Observations } & 41829 & 37660 & 8059\end{array}$

$\begin{array}{llll}R^{2} & .016 & .69 & .18\end{array}$

Note: This table shows the difference-in-difference estimate of the effect of the 2007 loan limit increase on full time faculty. Standard errors are clustered at the system level. Coefficients marked with $*, * *, * * *$, denote $\mathrm{p}<.1, \mathrm{p}<.05$, $\mathrm{p}<.01$, respectively.

Table B.5: Private Equity Ownership and Demographic Outcomes

\begin{tabular}{|c|c|c|c|c|c|c|}
\hline \multirow[t]{2}{*}{ Dependent variable: } & \multicolumn{2}{|c|}{$\begin{array}{c}\text { Share students } \\
\text { white }\end{array}$} & \multicolumn{2}{|c|}{$\begin{array}{c}\text { Pell grants per } \\
\text { FTE student }\end{array}$} & \multicolumn{2}{|c|}{$\begin{array}{c}\text { Percent } \\
\text { students on } \\
\text { federal grants } \\
\mathrm{NNM}^{ \pm}\end{array}$} \\
\hline & (1) & (2) & (3) & (4) & (5) & (6) \\
\hline \multirow[t]{2}{*}{ PE owned } & $-.05 * * *$ & .031 & -161 & $675 * *$ & .015 & $.041 *$ \\
\hline & {$[.0073]$} & {$[.028]$} & {$[269]$} & {$[319]$} & $(.013)$ & {$[.023]$} \\
\hline Composition controls $\ddagger$ & $\mathrm{N}$ & - & $\mathrm{N}$ & - & $\mathrm{N}$ & - \\
\hline School type controls ${ }^{\dagger}$ & $\mathrm{Y}$ & - & $\mathrm{Y}$ & - & $\mathrm{Y}$ & - \\
\hline School Fixed Effects & $\mathrm{Y}$ & - & $\mathrm{Y}$ & - & $\mathrm{Y}$ & - \\
\hline Year Fixed Effects & $\mathrm{Y}$ & - & $\mathrm{Y}$ & - & $\mathrm{Y}$ & - \\
\hline $\mathrm{N}$ & 123053 & 33610 & 123053 & 24503 & 87739 & 26197 \\
\hline$R^{2}$ & .92 & - & .61 & - & .75 & - \\
\hline
\end{tabular}

Note: This table shows regression estimates (OLS) of the effect of private equity ownership on school operational outcomes. Observations are at the school (UnitID)-year level. ${ }^{ \pm}$Nearest-neighbor matching is done within the sample of independent for-profit schools. The dependent variable is measured the year after the treated school's buyout. Matching is exactly on the year before the treated school's buyout, and then on characteristics (see Section 3.3 in main paper). ${ }^{\ddagger}$ We control for the share of students who are white, black, and Hispanic, and the average amount of federal Pell grants per student, a proxy for low-income students. ${ }^{\dagger}$ These are indicators for having selective admissions, public ownership, and are fixed effects for highest degree offered. The latter includes less than 2-year (certificate), 2-year, or 4-year. Standard errors two-way clustered by SystemID and year. Coefficients marked with $*, * *, * * *$, denote $\mathrm{p}<.1$, $\mathrm{p}<.05, \mathrm{p}<.01$, respectively.

\section{Online Appendix}


Table B.6: Effect on Graduation Rates by Changes in Education Inputs (Faculty per student, and Instruction Share of Spending)

Dependent Variable: Graduation rate in first year after buyout yerar

\begin{tabular}{|c|c|c|c|c|c|c|}
\hline Sample: & $\begin{array}{c}\Delta_{t-1, t}^{\text {Faculty }}< \\
25 \text { pctile }\end{array}$ & $\begin{array}{c}\Delta_{t-1, t}^{\text {Faculty }}> \\
25 \text { pctile }\end{array}$ & $\begin{array}{l}\text { Interaction between } \\
\text { PE and } \\
\Delta_{t-1, t}^{\text {Faculty }}<25 \text { pctile }\end{array}$ & $\begin{array}{c}\Delta_{t-1, t}^{\text {InstructShare }}< \\
25 \text { pctile }\end{array}$ & $\begin{array}{c}\Delta_{t-1, t}^{\text {InstructShare }}> \\
25 \text { pctile }\end{array}$ & $\begin{array}{c}\text { Interaction between } \\
\text { PE and } \\
\Delta_{t-1, t}^{\text {InstructShare }}<25 \\
\text { pctile }\end{array}$ \\
\hline
\end{tabular}

\begin{tabular}{|c|c|c|c|c|c|c|}
\hline & (1) & (2) & (3) & (4) & (5) & (6) \\
\hline \multirow[t]{2}{*}{$\mathrm{PE}$} & $-.13^{* * *}$ & $-.089^{* *}$ & $-.07 * *$ & -.074 & -.047 & -.047 \\
\hline & $(.038)$ & $(.031)$ & $(.029)$ & $(.059)$ & $(.035)$ & $(.032)$ \\
\hline \multirow[t]{2}{*}{$1 \mid<25$ th pctile } & & & -.0036 & & & .00017 \\
\hline & & & $(.0023)$ & & & $(.0022)$ \\
\hline \multirow[t]{2}{*}{ PE $\cdot 1 \mid<25$ th pctile } & & & -.019 & & & $-.06^{*}$ \\
\hline & & & $(.036)$ & & & $(.033)$ \\
\hline School Fixed Effects & $\mathrm{Y}$ & $\mathrm{Y}$ & $\mathrm{Y}$ & $\mathrm{Y}$ & $\mathrm{Y}$ & $\mathrm{Y}$ \\
\hline Year Fixed Effects & $\mathrm{Y}$ & $\mathrm{Y}$ & $\mathrm{Y}$ & $\mathrm{Y}$ & $\mathrm{Y}$ & $\mathrm{Y}$ \\
\hline Controls & $\mathrm{Y}$ & $\mathrm{Y}$ & $\mathrm{Y}$ & $\mathrm{Y}$ & $\mathrm{Y}$ & $\mathrm{Y}$ \\
\hline Observations & 5596 & 24021 & 30894 & 6638 & 20778 & 28215 \\
\hline$R^{2}$ & .82 & .89 & .86 & .86 & .89 & .86 \\
\hline
\end{tabular}

Note: This table shows whether the effect of private equity buyouts on graduation rates in the first year after the buyout (i.e., the immediate effect) is larger among schools where there is a larger immediate decline in education inputs. We consider only the year after the buyout, to focus on drivers of the immediate decline in graduation rates. We use two types of education inputs: FTE faculty per 100 students (columns 1-3) and the instruction share of total spending (columns 4-6). The first two columns for each split the sample below and above the 25th percentile for the change in education input between the year before and the year after the buyout. The third column interacts an indicator for whether the change in education input is below the 25th percentile with the PE indicator. Letting $t$ represent the first affected buyout year, the estimating equation for this interaction model is $Y_{i, t}=\alpha_{i}+\alpha_{t}+\beta_{1} P E_{i, t} \cdot\left(\Delta_{t-1, t}^{\text {EducInput }}<25\right.$ th pctile $)+\beta_{2} P E_{i, t}+$ $\beta_{3}\left(\Delta_{t-1, t}^{\text {EducInput }}<25\right.$ th pctile $)+\gamma \mathbf{X}_{i t}+\varepsilon_{i t}$. Here, $\Delta_{t-1, t}^{\text {EducInput }}<25$ pctile indicates that the change in education input between $t-1$ and $t$ is less than its 25 th percentile. The 25 th percentile is -.4 for faculty, and -.018 for instruction spending share. ${ }^{*}$ Standard errors are clustered at the system level. Coefficients marked with $*, * *, * * *$ denote $\mathrm{p}<.1, \mathrm{p}<.05, \mathrm{p}<.01$, respectively. 
Table B.7: Effect of Buyouts on Degree Cuts in First Two Years after Buyout

Dependent Variable: Degree cuts

\begin{tabular}{lccc} 
& $(1)$ & $(2)$ & $(3)$ \\
PE owned & .00085 & -.012 & -.014 \\
& $(.071)$ & $(.034)$ & $(.012)$ \\
Controls & $\mathrm{Y}$ & $\mathrm{Y}$ & $\mathrm{Y}$ \\
School Fixed Effects & $\mathrm{Y}$ & $\mathrm{Y}$ & $\mathrm{Y}$ \\
Year Fixed Effects & $\mathrm{Y}$ & $\mathrm{Y}$ & $\mathrm{Y}$ \\
$R^{2}$ & 2399 & 2399 & 2399 \\
Observations & .37 & .39 & .42 \\
\hline \hline
\end{tabular}

Note: This table shows the relationship between private equity buyouts and degree cuts. A degree cut is the removal of a degree from the school's offerings. There are a total of 230 possible degree offerings. We restrict the sample to PE targets, and to no more than two years after the buyout. Standard errors are double-clustered at the system and year levels. Coefficients marked with $*, * *, * * *$, denote $\mathrm{p}<.1, \mathrm{p}<.05, \mathrm{p}<.01$, respectively. 
Table B.8: Private Equity Ownership Compared to Chain Acquisitions

\begin{tabular}{|c|c|c|c|c|c|c|c|}
\hline \multirow[t]{2}{*}{ Dependent variable: } & $\begin{array}{l}\text { Graduation } \\
\text { rate }\end{array}$ & $\begin{array}{l}\text { Repayment } \\
\text { rate }\end{array}$ & $\begin{array}{c}\text { Log } \\
\text { mean } \\
\text { earnings }\end{array}$ & $\begin{array}{l}\text { Average } \\
\text { loan per } \\
\text { borrower }\end{array}$ & $\begin{array}{c}\text { Tuition per } \\
\text { student } \\
(2015 \$)\end{array}$ & $\begin{array}{l}\text { Faculty } \\
\text { per } 100 \\
\text { students }\end{array}$ & $\begin{array}{l}\text { Log number } \\
\text { of FTE } \\
\text { students }\end{array}$ \\
\hline & (1) & (2) & (3) & (4) & (5) & (6) & (7) \\
\hline \multirow{2}{*}{$\begin{array}{l}\text { PE buyout } \\
\text { (acquisitions only) }^{\dagger}\end{array}$} & $-.06 * *$ & $-.037 * *$ & $-.064 *$ & $1032 * * *$ & $3668 * * *$ & $-.31 *$ & $.46^{* * *}$ \\
\hline & {$[.02]$} & {$[.011]$} & {$[.025]$} & [229] & [721] & {$[.15]$} & {$[.063]$} \\
\hline \multirow[t]{2}{*}{ Non-PE chain* } & $-.043 * *$ & -.019 & $-.037 * * *$ & 553 & -183 & -.17 & $.21 * * *$ \\
\hline & {$[.017]$} & {$[.012]$} & {$[.009]$} & {$[393]$} & {$[546]$} & {$[.3]$} & {$[.055]$} \\
\hline School type controls ${ }^{\dagger}$ & $\mathrm{Y}$ & $\mathrm{Y}$ & $\mathrm{Y}$ & $\mathrm{Y}$ & Y & $\mathrm{Y}$ & $\mathrm{Y}$ \\
\hline School Fixed Effects & $\mathrm{Y}$ & $\mathrm{Y}$ & $\mathrm{Y}$ & Y & $\mathrm{Y}$ & $\mathrm{Y}$ & $\mathrm{Y}$ \\
\hline Year Fixed Effects & $\mathrm{Y}$ & $\mathrm{Y}$ & $\mathrm{Y}$ & $\mathrm{Y}$ & Y & $\mathrm{Y}$ & $\mathrm{Y}$ \\
\hline $\mathrm{N}$ & 56965 & 28201 & 24652 & 77497 & 102355 & 62432 & 123053 \\
\hline$R^{2}$ & .8 & .96 & .97 & .67 & .82 & .83 & .97 \\
\hline
\end{tabular}

Note: This table shows regression estimates (OLS) of the effect of ownership type on primary outcomes. ${ }^{\dagger}$ This is an indicator for an acquisition of an independent school by a private equity-owned school system. ${ }^{*}$ This is an indicator for an independent school being purchased by a non-private equity owned chain. We define a "chain" as any parent company (SystemID) that is neither publicly traded nor private equity-owned and that owns at least two schools (UnitIDs). Observations are at the school (UnitID)-year level. Standard errors two-way clustered by SystemID and year. ${ }^{\dagger}$ Defined as in previous tables. Coefficients marked with $*, * *, * * *$, denote $\mathrm{p}<.1, \mathrm{p}<.05, \mathrm{p}<.01$, respectively. 
Figure B.1: Share of private equity investment in government subsidy-intensive sectors as share of overall private equity investment, 1995-2016
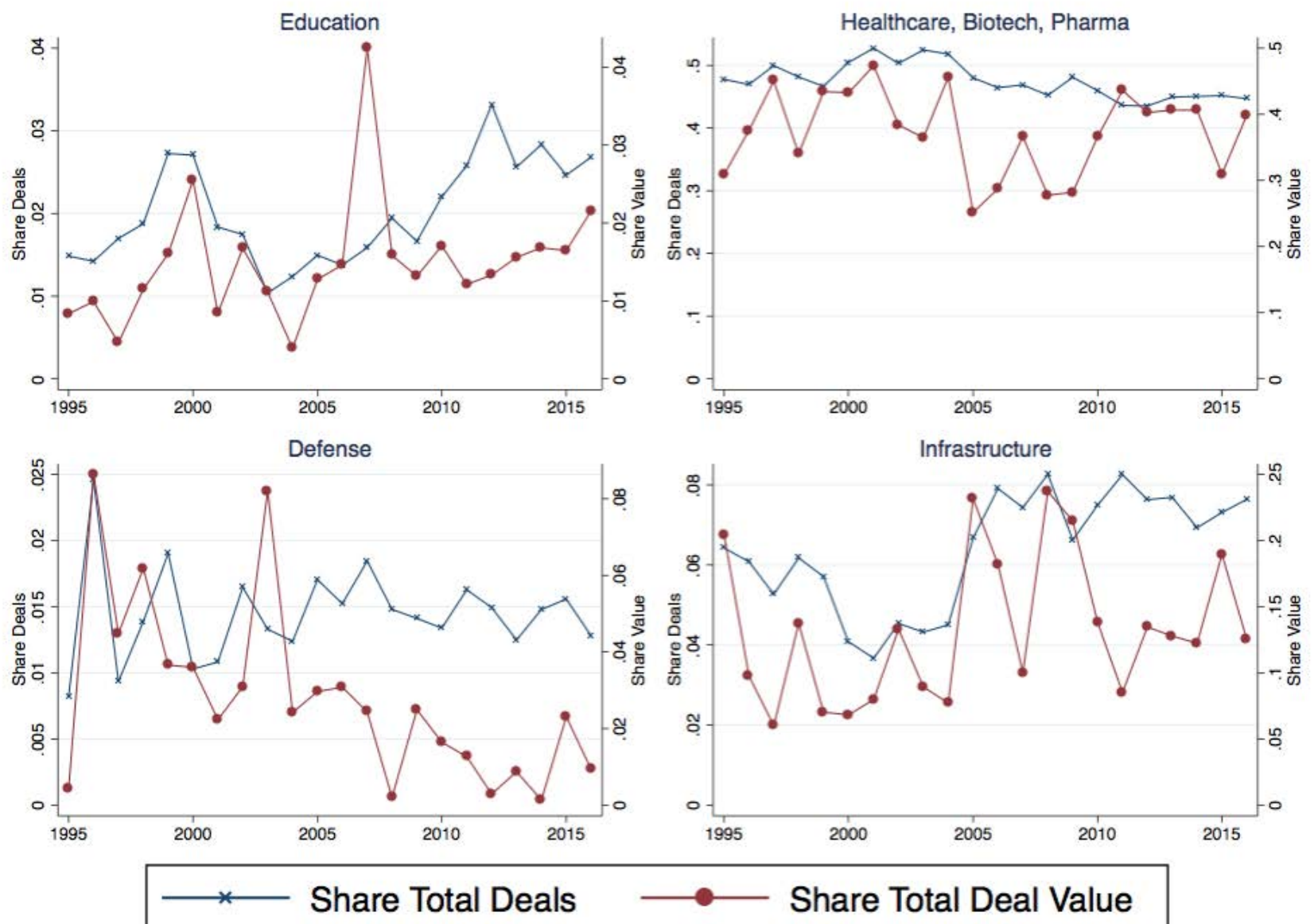

Note: All global private equity transactions included. Total value was $\$ 716$ billion in 2016, up from just $\$ 19$ billion in 1995. Source: CIQ. 
Figure B.2: Private Equity Deals and School Ownership

Panel A: Bar Charts of Buyout Deals and School Ownership Changes by Year

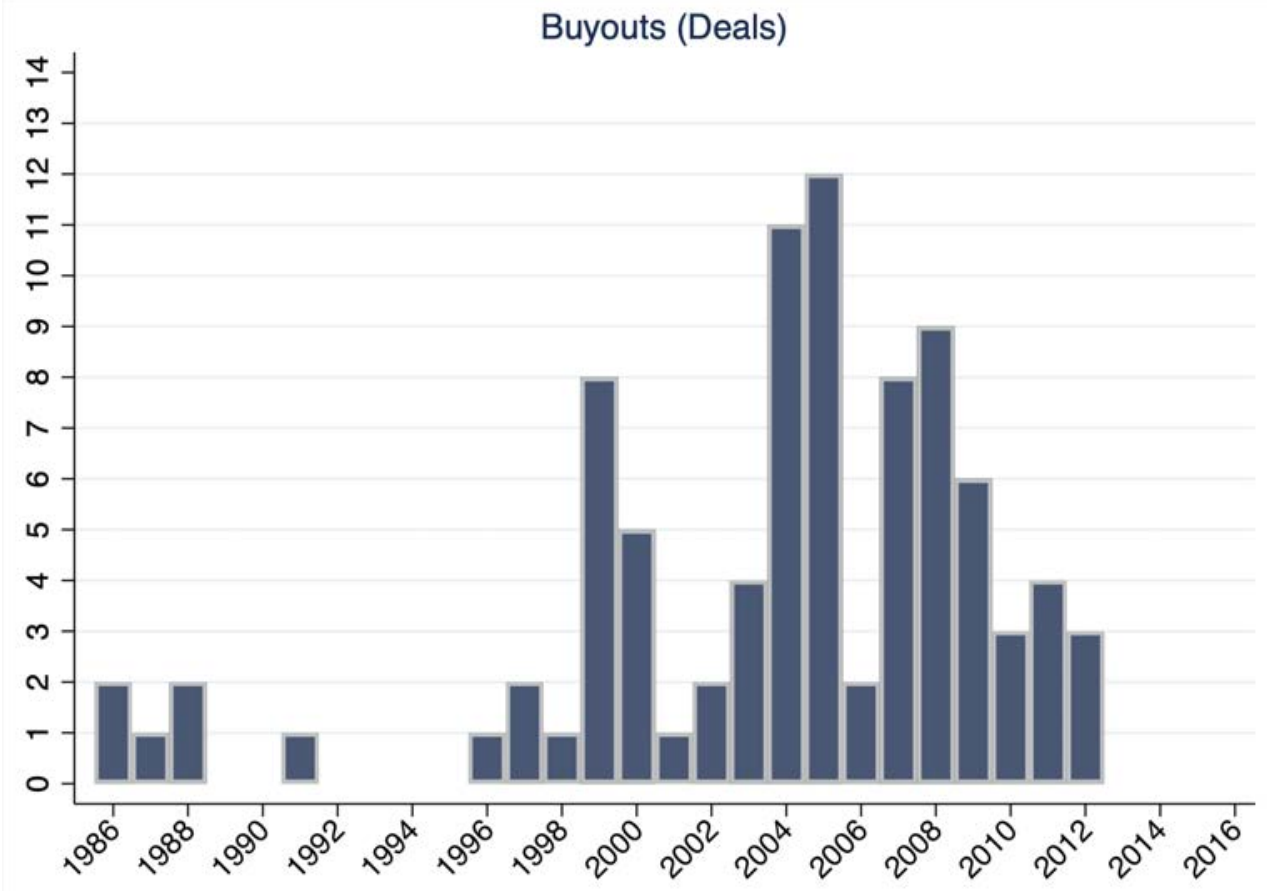

All Ownership Changes (Total Schools)

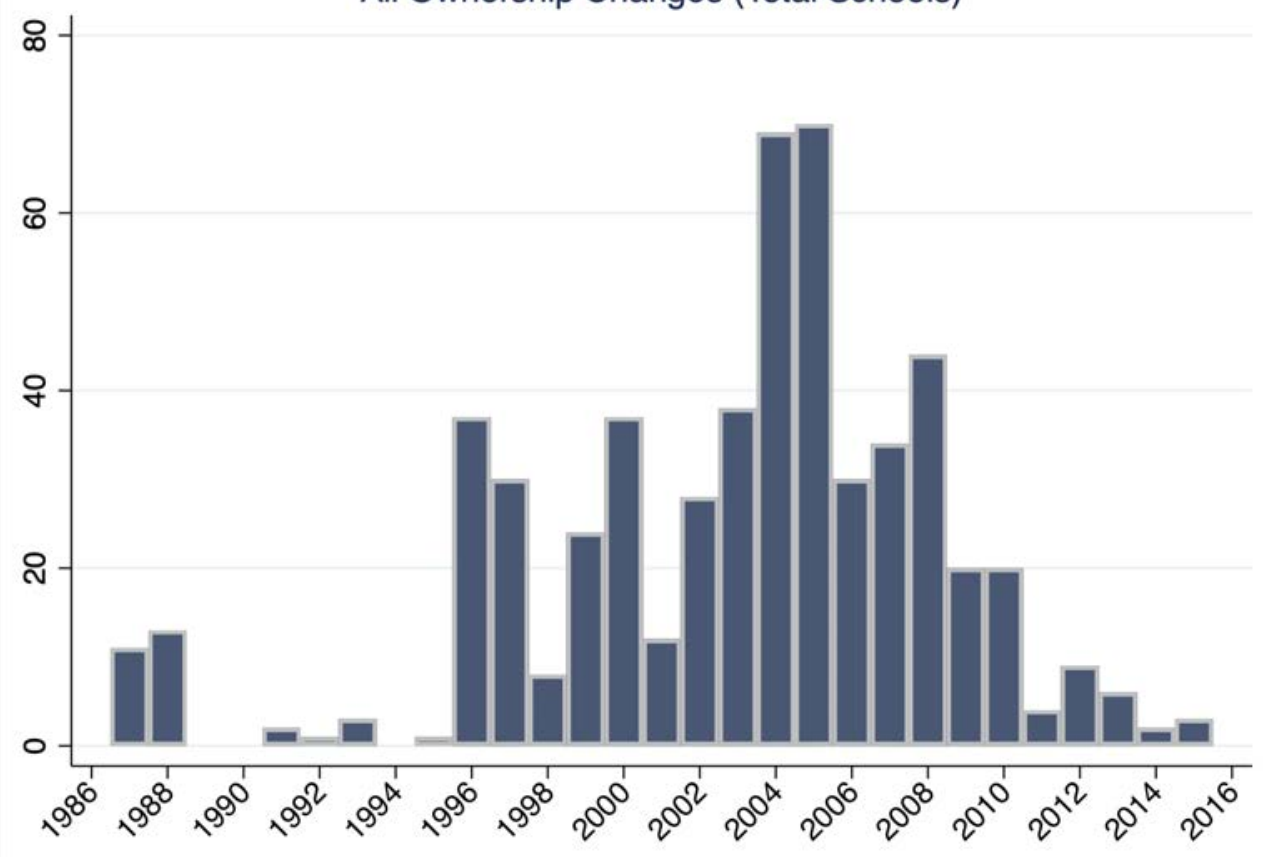

Note: The top graph shows the number of private equity buyouts of independent schools or chains of schools by year. The total is 88. The bottom graph shows school (UnitID)-level changes to private equity ownership. The total is 557. 
Panel B: Histograms of Colleges Purchased in Buyout Deals and Subsequent Acquisitions
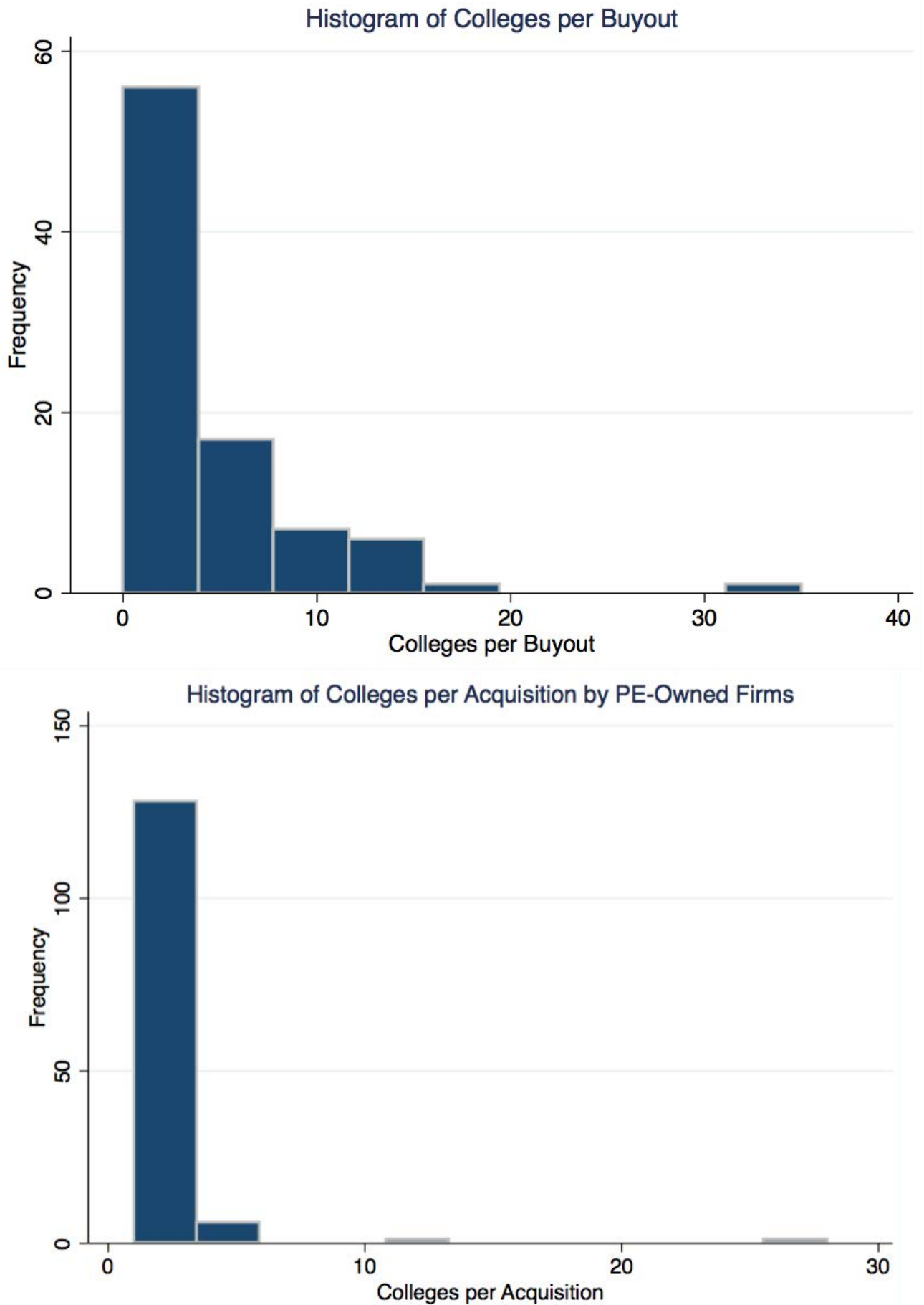

Note: The top graph shows the concentration of colleges per buyout, and the bottom graph shows the concentration in subsequent acquisitions. These demonstrate that most deals involve a single school, but some involve more than one. 
Figure B.3: Federal Grants Event Study

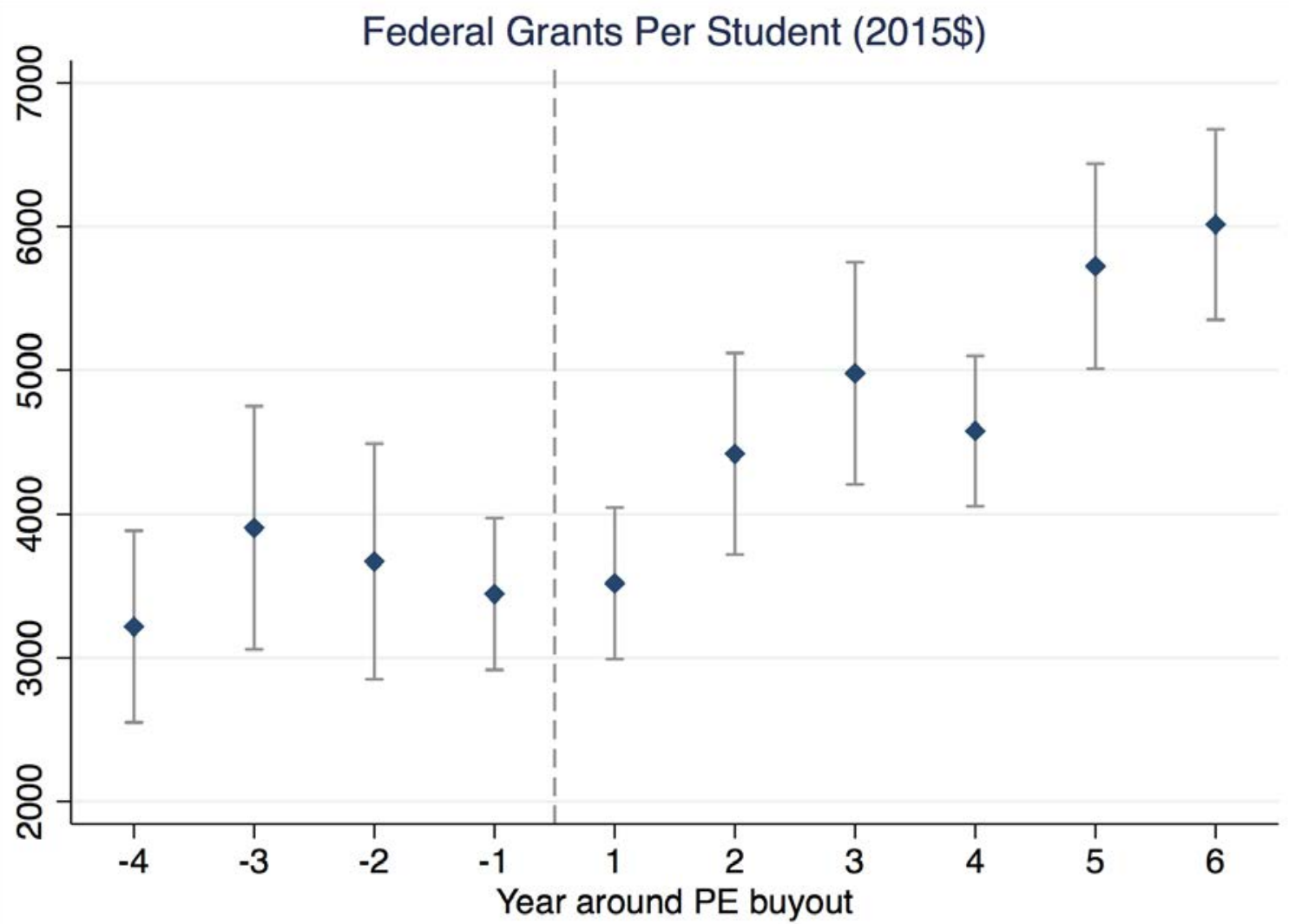

Note: The figure above shows, within the sample of school systems bought by PE, the mean of federal grants per student in the years around the ownership change. $95 \%$ confidence intervals shown. 
Figure B.4: Financial Event Studies
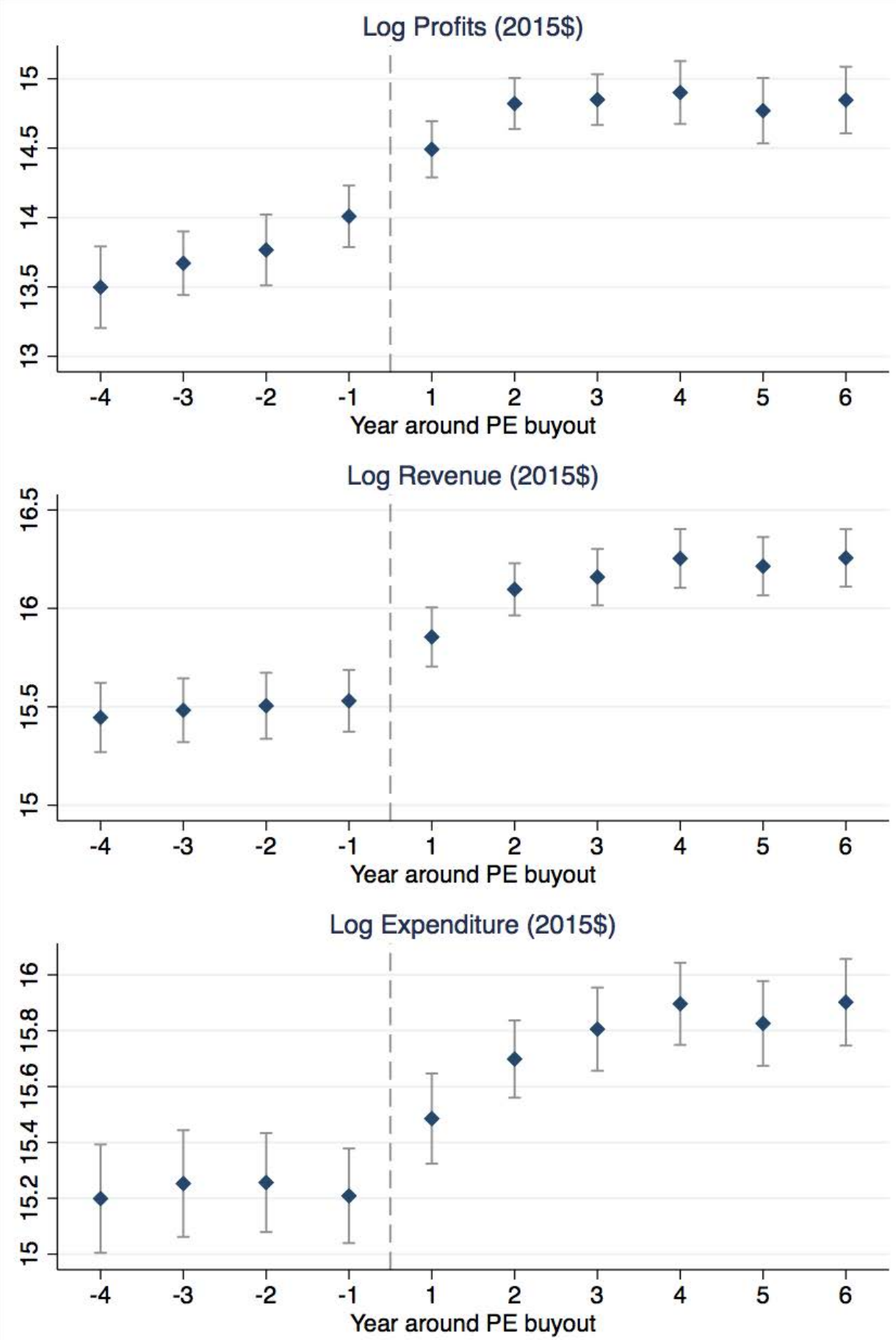

Note: The figure above shows, within the sample of school systems bought by PE, the mean of profits, revenues, and expenditure in the years around the ownership change. $95 \%$ confidence intervals shown. 
Figure B.5: Distance from 90/10 Threshold

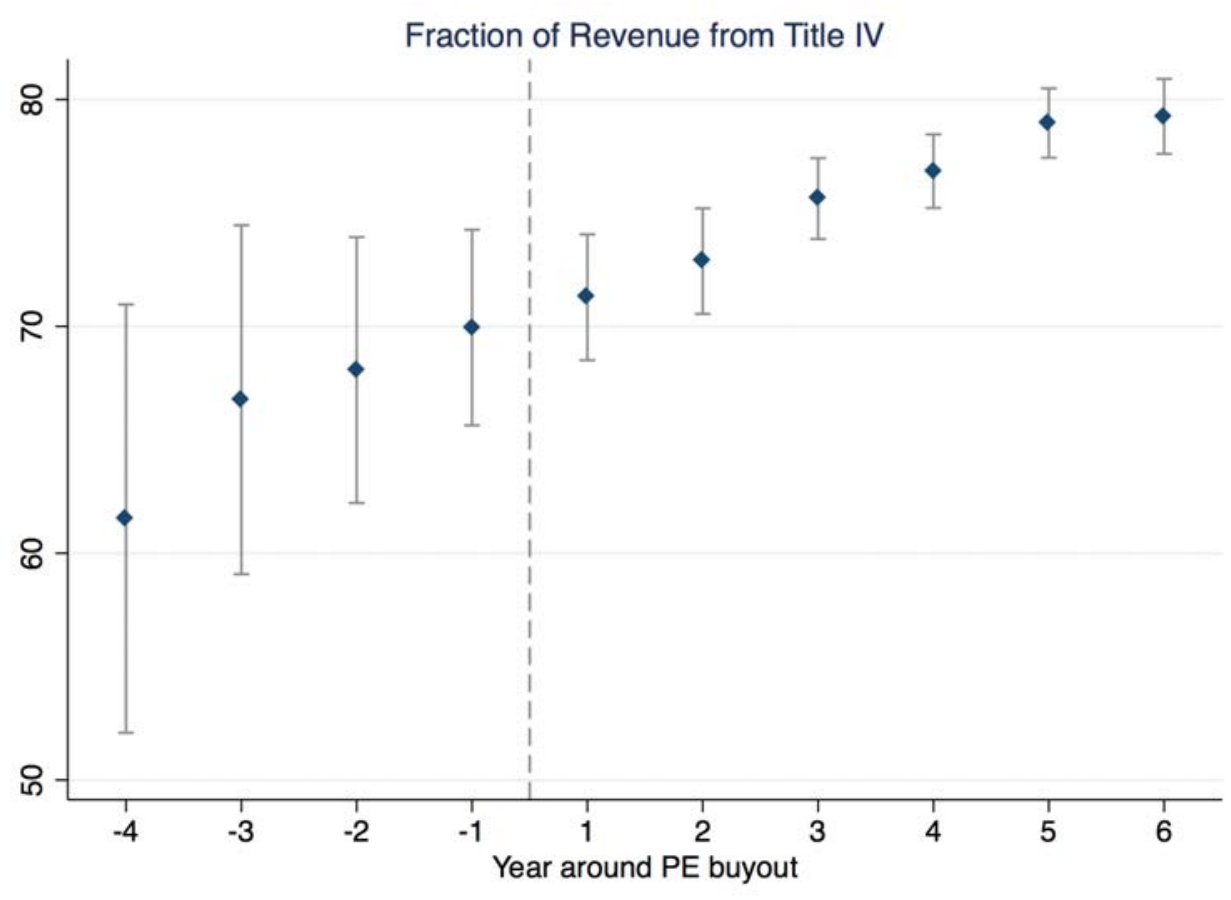

Note: The figure above shows, within the sample of school systems bought by PE, the average fraction of school revenue from Title IV programs in the years around the ownership change. The level of observation is the SystemID. We restrict the observations to schools that existed in the year prior to the buyout. 95\% confidence intervals shown. The data source is the Department of Education FSA Proprietary School 90/10 Revenue Percentages. Data are available from 2007 to 2016. 
Figure B.6: Borrowing at Private Equity Institutions

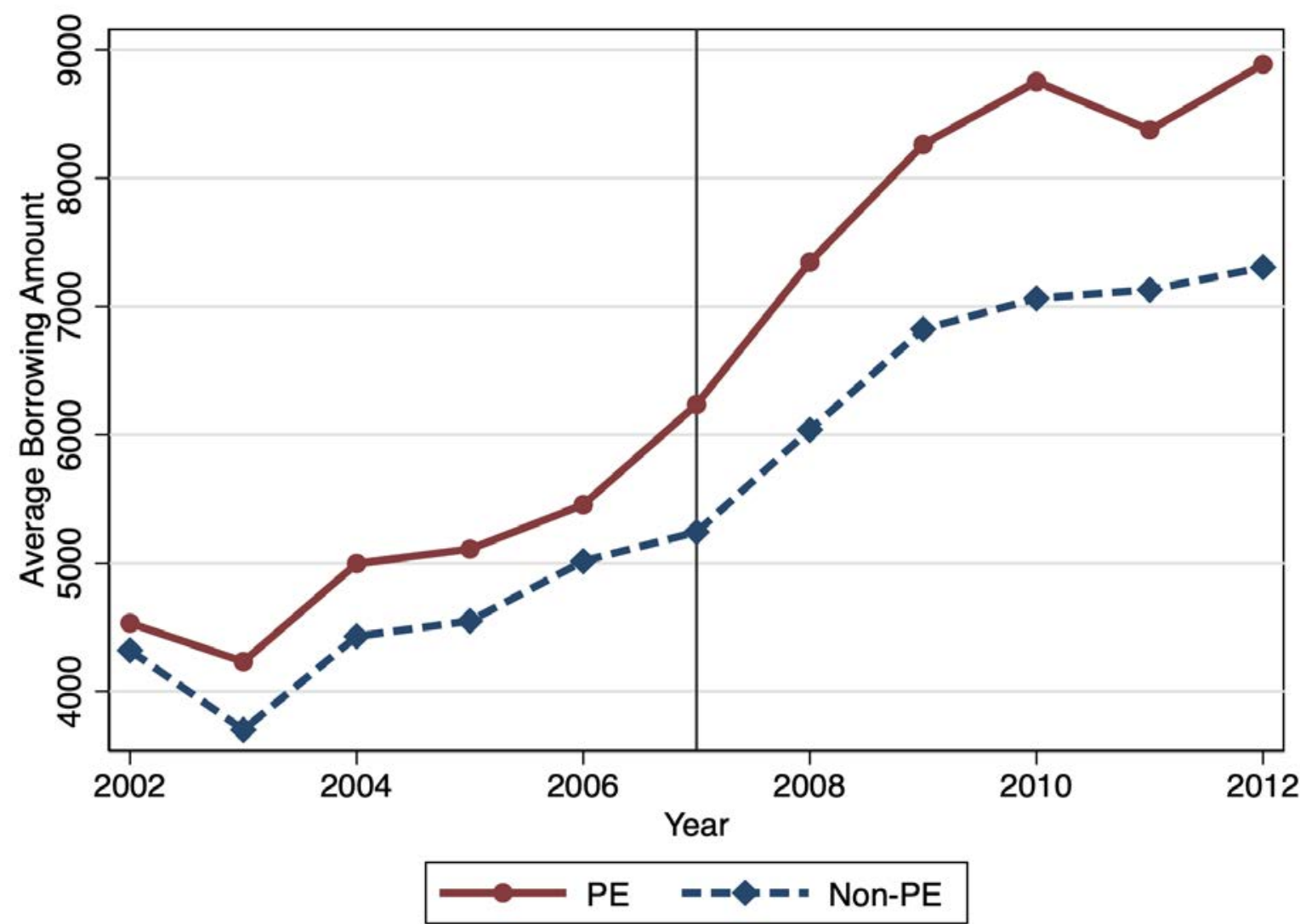

Note: This figure shows borrowing at PE-owned schools bought before 2007, and borrowing at other for-profits. The vertical line shows 2007, when student borrowing limits were increased. 
Figure B.7: Earnings Event Study (Time Demeaned)

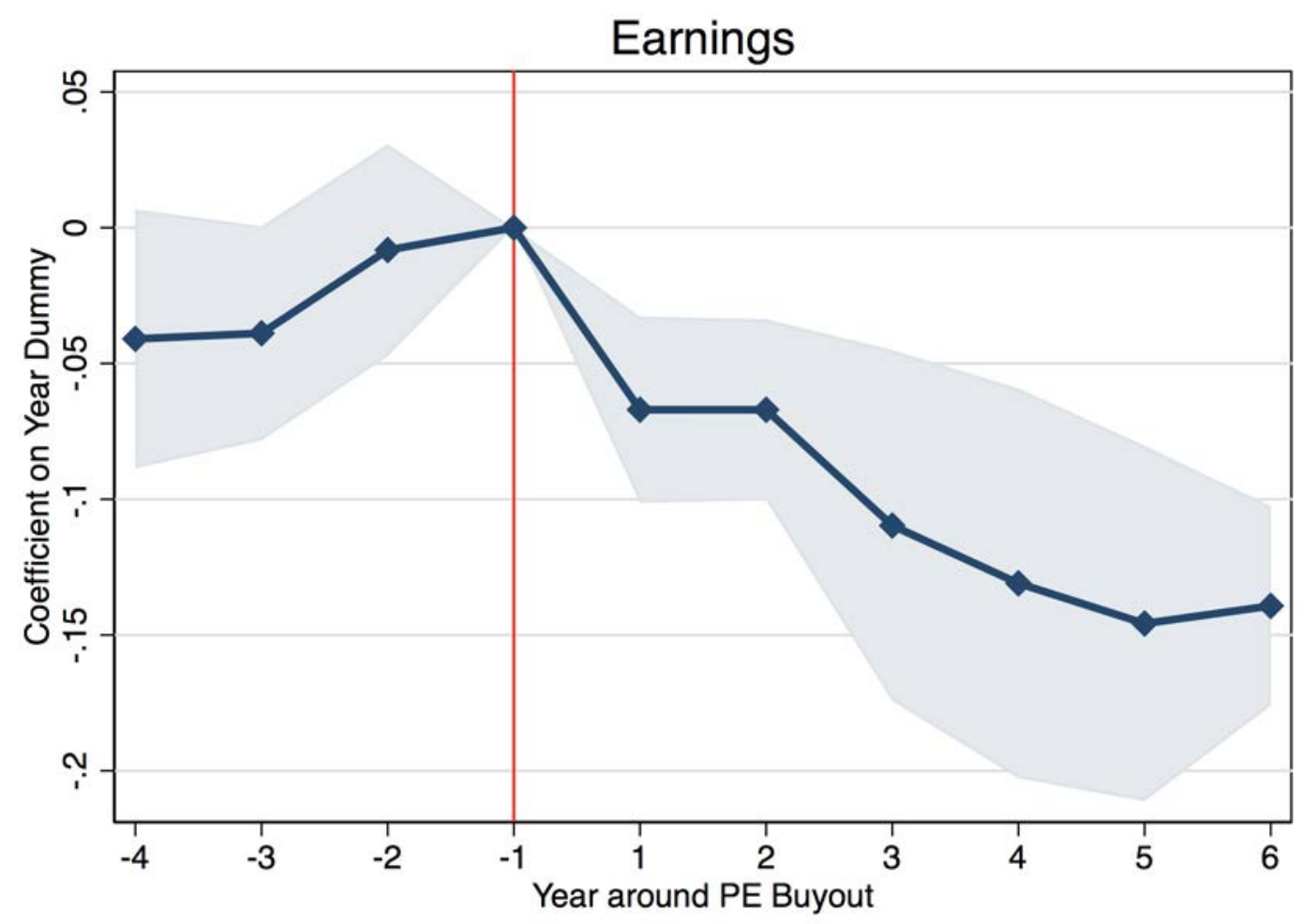

Note: This figure shows the coefficients $\beta_{j}$ from the following specification:

$$
\text { lnWages }_{i t}=\alpha_{i}+\alpha_{t}+\sum_{j=-4}^{3} \beta_{j} 1\left[\text { Year }=\text { Year }_{P E}+j\right]+\varepsilon_{i t}
$$

Here, $1\left[\right.$ Year $=$ Year $\left._{P E}+j\right]$ is an indicator of a year before or after the buyout year. The year before the buyout $(-1)$ is the baseline, normalized to zero. We also include school and year fixed effects $\left(\alpha_{i}\right.$ and $\left.\alpha_{t}\right)$. The sample is all schools, and the control group is all non-private equity-owned schools. The area denotes a $95 \%$ confidence interval. This data is at the school, or UnitID level $(\mathrm{N}=697)$. We restrict the observations to schools that existed in the year prior to the buyout. 
Figure B.8: Education Inputs Event Studies
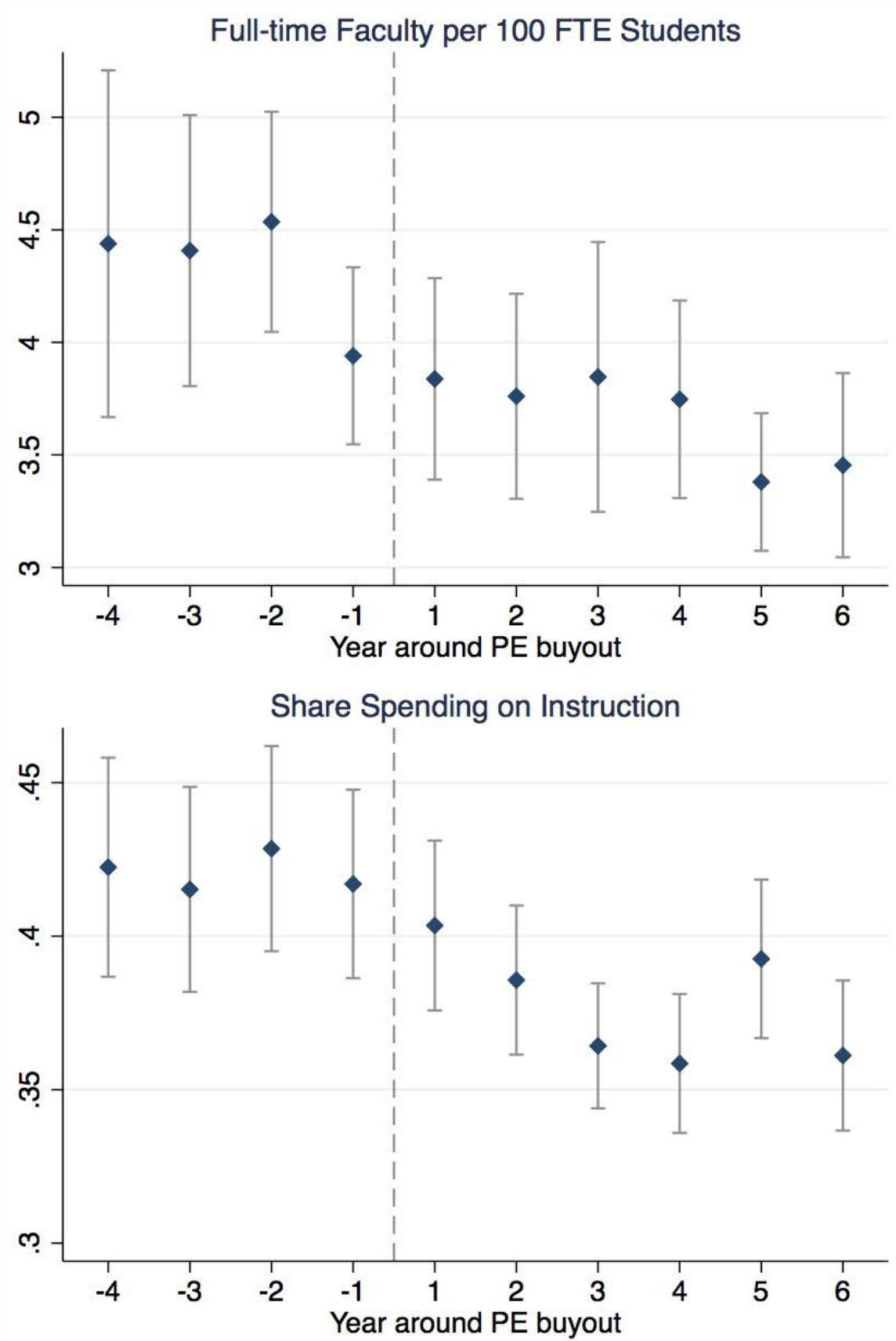

Note: Panel A shows, within the sample of school systems bought by PE, the mean of full-time faculty per 100 FTE students in the years around the ownership change. Panel B shows, within the sample of school systems bought by PE, the mean of the share of spending on instruction in the years around the ownership change. 95\% confidence intervals shown. 
Figure B.9: Relationship between Graduation Rate Changes and Other Variables In Year Following Buyout
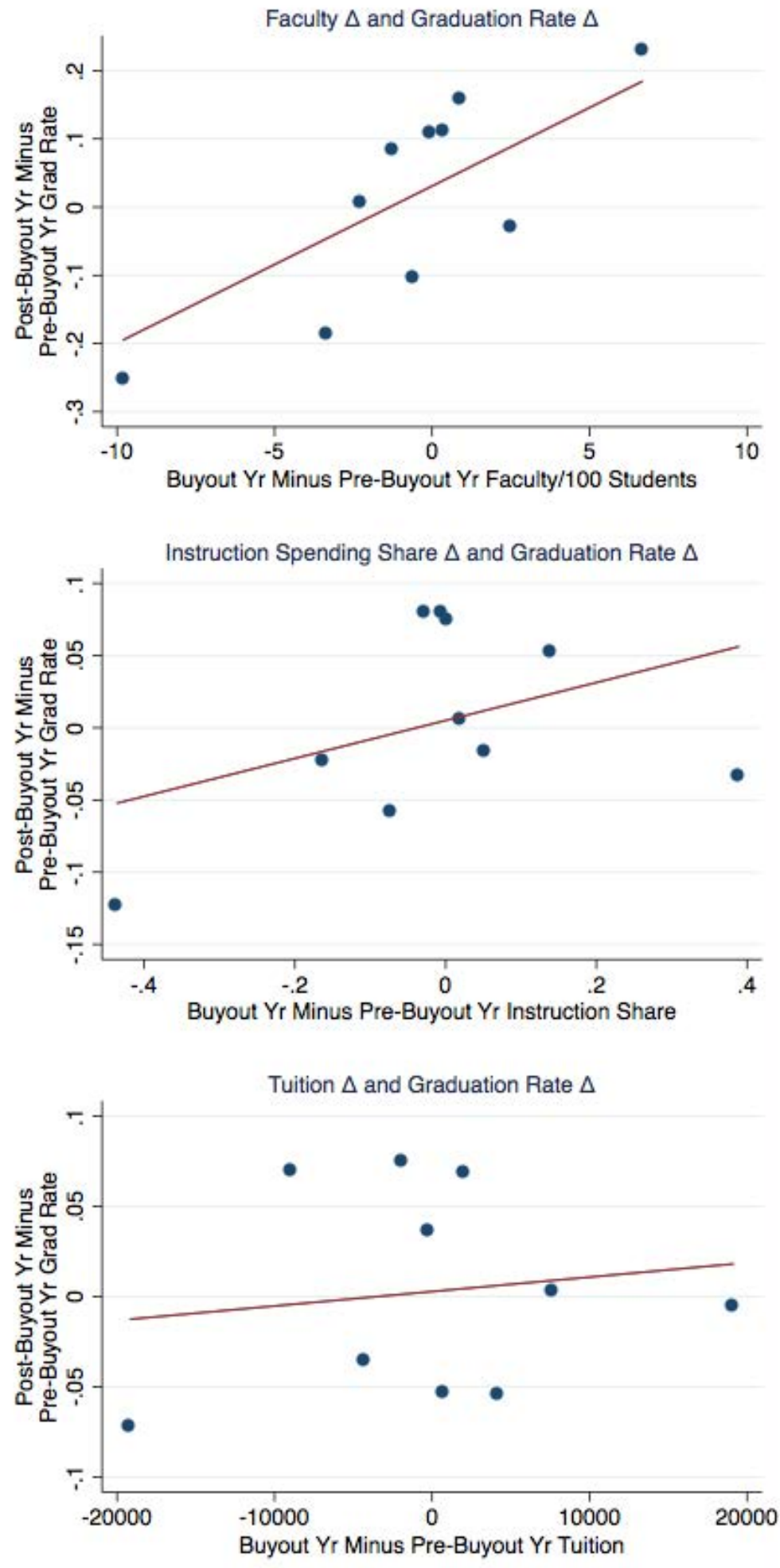

Note: Panel A contains a binscatter relating changes in faculty per 100 students (x-axis) to graduation rates (y-axis), between the two years before and after the buyout. Panels B and C repeat this analysis but with the instruction share of expenditure and tuition on the $\mathrm{x}$-axis, respectively. 
Figure B.10: Enrollment Event Study

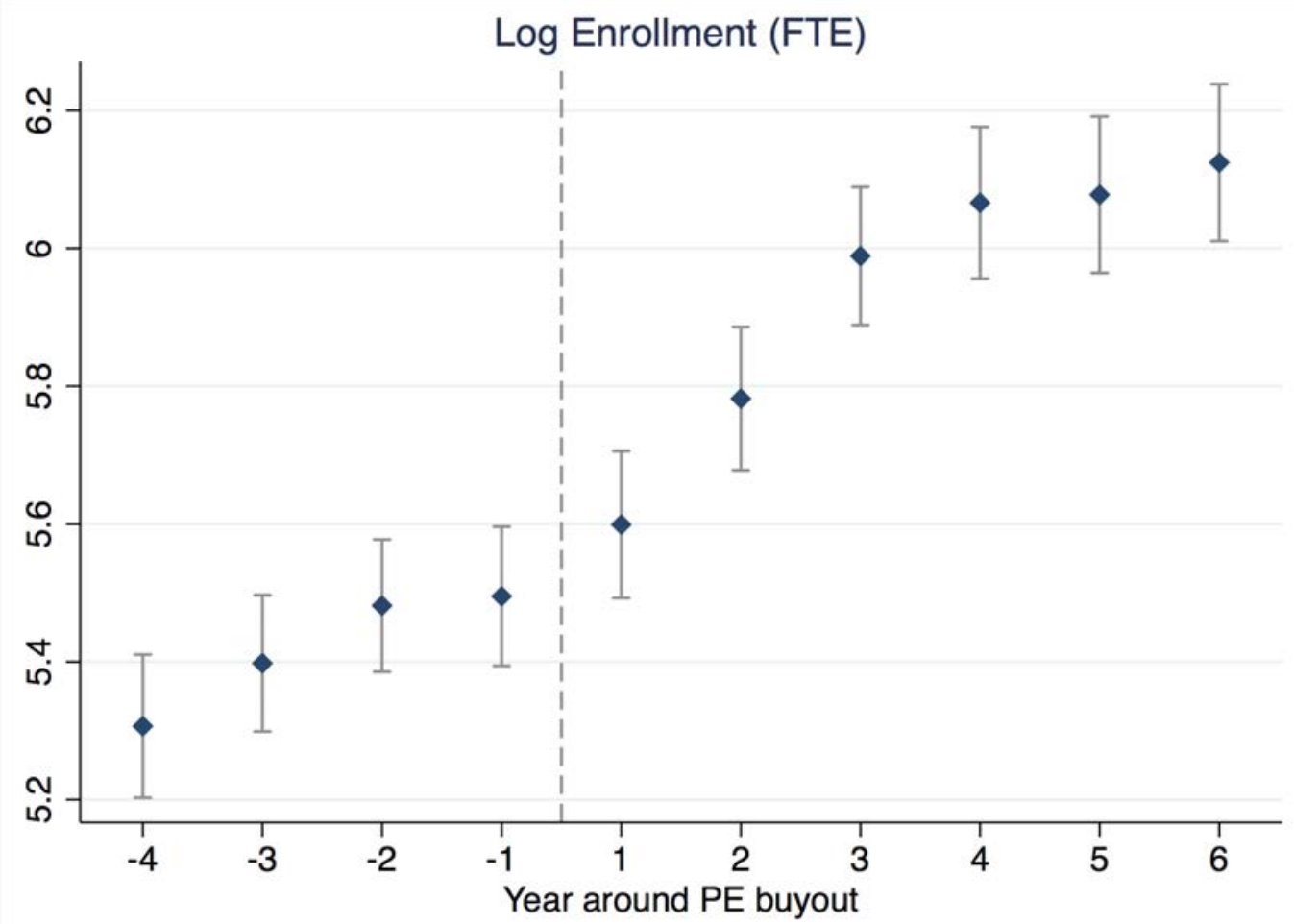

Note: The figure above shows, within the sample of school systems bought by PE, the mean of enrollment in the years around the ownership change. $95 \%$ confidence intervals shown. 
Figure B.11: Law Enforcement Actions by School Type

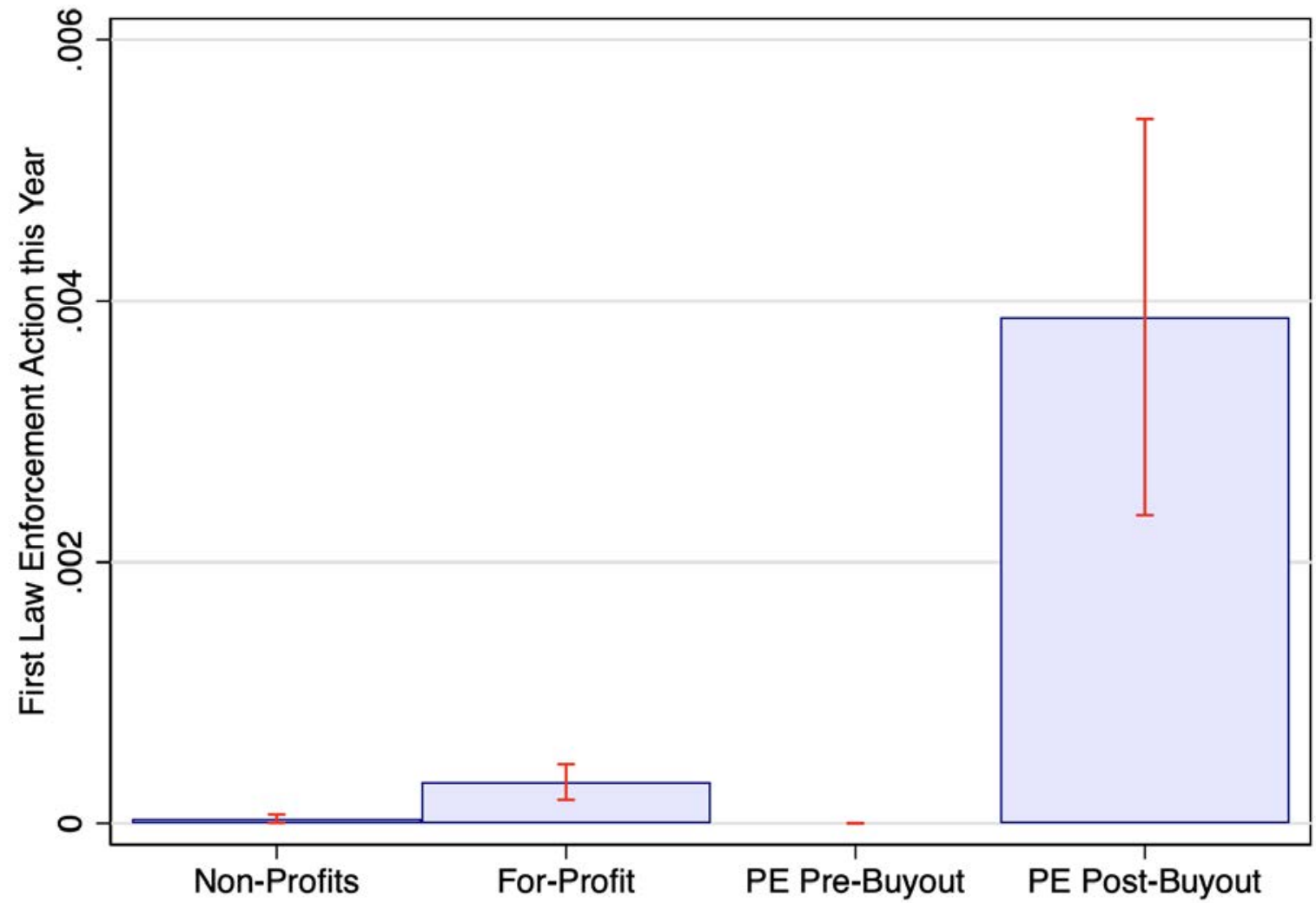

Note: This figure shows the chances in a given year that a school has its first law enforcement action. 
Figure B.12: Degree Cuts Around Buyouts
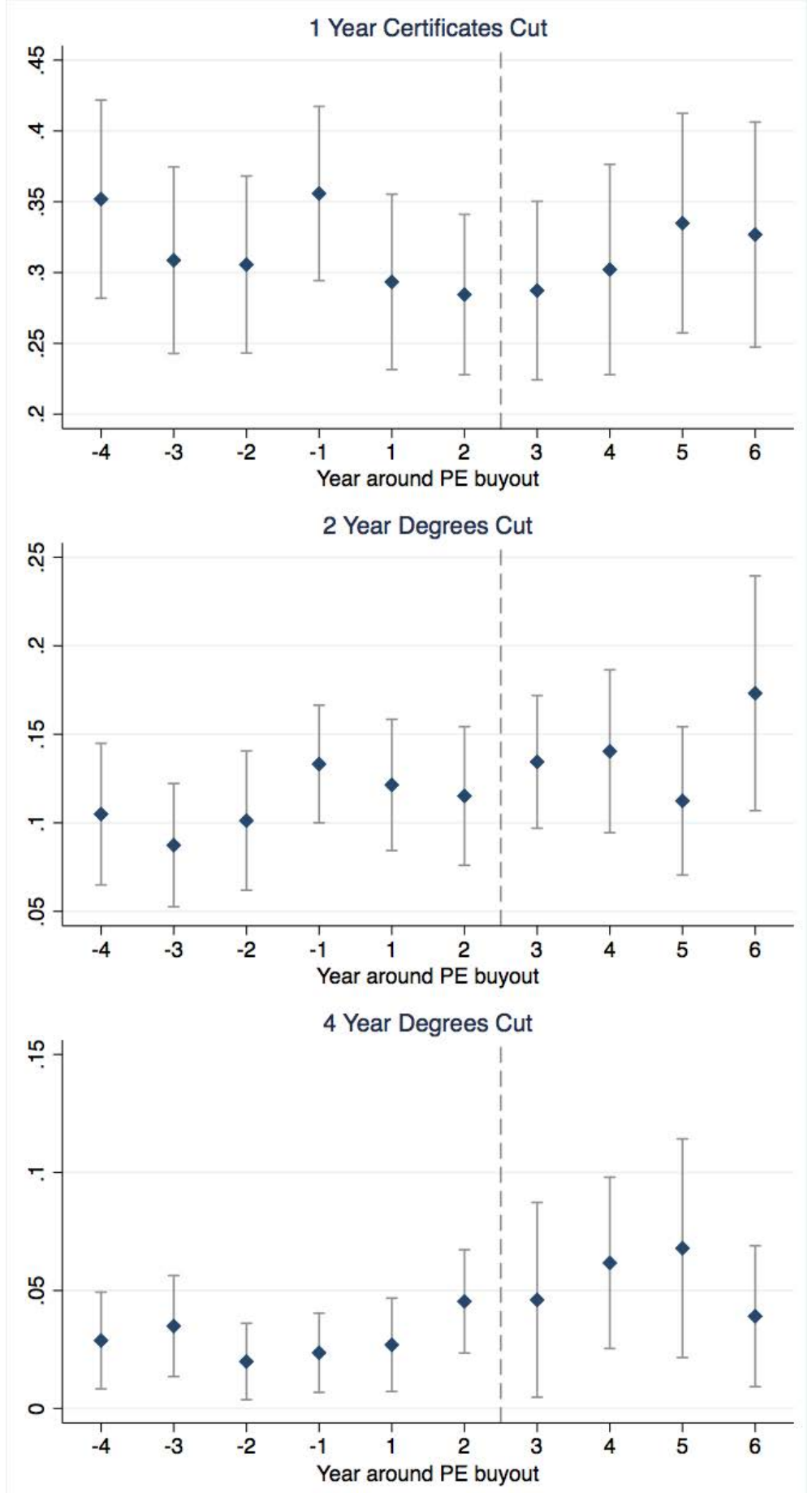

Note: These plots show the number of degree cuts by year around private equity buyouts, within schools that switched from independent to private equity-owned. A degree cut is the removal of a degree from the school's offerings. There are a total of 230 possible degree offerings. 


\section{Appendix C: Subsidy Capture Tests}

\section{C.1 Cohort Default Rate Bunching}

A key determinant of federal aid eligibility that has been consistently in force for decades is a limit on the extent to which students can default. School survival depends on not triggering these thresholds. Before 2012, the policy held that the share of students that default in the fiscal year after the fiscal year in which they graduated cannot exceed 25 percent for three years in a row, nor can it be higher than 40 percent in a single year. The two-year cohort default rate (CDR) is the fraction of students within a certain repayment cohort who default within two years of entering repayment, which may be vulnerable to manipulation (Looney and Yannelis (Looney and Yannelis)).

We find evidence that private equity-owned institutions are better at avoiding the threshold. Appendix C Figure 1 shows the density of two-year cohort default rates by institution type. We restrict the sample to pre-2012, as the policy changed somewhat in that year. ${ }^{14}$ The solid line shows private equity-owned institutions, and the other two lines show independent for-profit and nonprofit schools. The vertical line is the 25 percent two-year CDR threshold. CDRs largely evolve smoothly across the threshold among independent for-profits and other schools. In contrast, there is a sharp drop in the default density right before the threshold at private equity-owned schools, consistent with avoiding the threshold.

\section{C.2 Gainful Employment Announcement}

In this section, we present evidence that the market value of for-profit postsecondary schools is tightly connected to their ability to access federal aid regardless of student outcomes. We exploit four events comprising the introduction, watering down and eventual end of the Gainful

\footnotetext{
${ }^{14}$ In 2012, the CDR calculation was changed from a two-year to a three-year window (that is, default is now measured in the second fiscal year after graduation). To partially compensate for this more onerous policy, the 25 percent was changed to 30 percent. The rule change was expected to be very detrimental to for-profit colleges (see e.g. http://www.finaid.org/loans/cohortdefaultrates.phtml).
} 
Employment (GE) rule, which aimed to tie a school's access to federal grants and federally guaranteed loans to student labor market performance. Consistent with for-profit schools capturing government aid, we find that the market values of publicly traded for-profits fell sharply when the GE rule was announced. Conversely, affected firms experienced positive abnormal returns when the rules were weakened and ultimately vacated.

This analysis uses data on publicly traded firms. While this approach may seem somewhat disconnected from the paper's focus on private equity, in fact it serves to highlight the role of private equity in building the modern for-profit higher education sector. Currently, the largest purveyors of for-profit higher education are publicly traded, and all of the major public companies have at some point been private equity-owned. We document this in Appendix C Table 1. All received private equity investment prior to going public, except for Strayer University, which was taken private in a reverse LBO in 2001. The results in Section 4 revealed that the behavior of these formerly private equity owned, publicly traded schools is more similar to private equity owned, privately held schools than to other for-profits. Therefore, this section is both an extension of the private equity analysis, and also demonstrates the relationship between federal aid access and future cash flows for all for-profits with higher powered incentives than either independent, privately held for-profits or community colleges and other nonprofit institutions.

First announced on July 26, 2010, the GE rule would have required graduates to meet debtto-earnings requirements in order for the college to remain eligible for federal aid. ${ }^{15}$ The goal was to eliminate programs in which students took on debt that was unmanageable relative to their expected labor market outcomes. Following the initial announcement, the rules were revised on June 2, 2011. This change substantially weakened the original rules. ${ }^{16}$ In 2017 , the rules were

\footnotetext{
${ }^{15}$ Specifically, to remain Title IV-eligible, all for-profit and certificate programs would have had to pass at least one of three metrics: 1) at least 35 percent of former students must be in active repayment, defined as reducing their loan annually by at least $\$ 1 ; 2$ ) annual loan payments could not exceed 30 percent of a typical graduate's discretionary income; or 3) annual loan payments could not exceed 12 percent of a typical graduate's total earnings. See IFAP and US News for more information.

${ }^{16}$ Under the 2010 rules, if a school failed three tests, the school would immediately lose access to federal grants and loans. Under the new rules, if schools failed three tests three times in a four year span, access to federal grant and loans programs would be cut. The tests are that (1) at least 35 percent of students are paying down their loans, (2) graduates on average are spending less than 12 percent of their total income on loan payments and (3) graduates on average must be spending less than 30 percent of their discretionary income on loan payments. See the announcement
} 
suspended altogether. ${ }^{17}$

Cumulative abnormal returns follow Campbell et al. (1997) and Acemoglu et al. (2016). The abnormal return for stock $i$ at date $t$ is given by

$$
A R_{i t}=R_{i t}-\left(\hat{\alpha}_{i}+\hat{\beta}_{i} R_{m t}\right)
$$

where $R_{i t}$ is the return of stock $i$ at date $t$, and $R_{m t}$ is the market return. The terms $\hat{\alpha}_{i}$ and $\hat{\beta}_{i}$ are estimated from the following equation

$$
R_{i t}=\alpha_{i}+\beta_{i} R_{m t}+\varepsilon_{i t}
$$

Equation 2 is estimated for the 250 day trading period from 270 days prior to the event period. ${ }^{18}$ The abnormal return in Equation 1 is calculated for each day of the event window, which encompasses the 20 trading days before to the 20 trading days after the event date. Firms are excluded if they are in the data for fewer than 150 days of the estimation window or fewer than 20 days of the event window.

Cumulative abnormal returns (CAR) are then calculated as

$$
C A R[0, n]=\sum_{t=0}^{n} A R_{i t},
$$

where $n$ is the day following the start of the analysis period, 20 trading days prior to the event date. We compare fifteen firms that own for-profit institutions with GE data available between 2010 and 2015. Control firms for the event studies are publicly traded firms with the same first three-digit NAICS as those in the treatment sample. Thus, the control firms are those with NAICS codes with 611 (Educational Services) and 812 (Personal Services) as the first three digits, which includes 48 controls firms in total.

\footnotetext{
for more information.

${ }^{17}$ See the Washington Post for more information.

${ }^{18}$ This estimation period is chosen to prevent the estimation period from influencing market returns and the expected return calculation.
} 
Appendix C Figure 2 shows the CAR results. Each panel shows CAR values before and after a regulatory event. Time denotes days, and prices are measured at the close of each trading day. The left hand panel shows the announcement of the GE rules on July 26, 2010. ${ }^{19}$ There is a sharp drop in CAR for exposed firms. In contrast, we see no discernible pattern for education firms unaffected by the GE rules. The right hand panel in Appendix C Figure 2 shows the jump in CAR following the June 2, 2011 rule weakening. Again we see no response for the control group.

Appendix $\mathrm{C}$ Table 2 presents results analogous to those in the figure. We use variants of the following specification

$$
C A R_{i t}=\alpha_{i}+\alpha_{t}+\delta F P_{i} * \text { Post }_{t}+\varepsilon_{i t},
$$

where $C A R_{i t}$ are the cumulative abnormal returns for firm $i$ on day $t$. We include firm effects $\alpha_{i}$, which absorb time invariant firm specific factors. Trading day fixed effects $\alpha_{t}$ absorb market-wide factors. The coefficient of interest is $\delta$, which gives us the differential effect of the treatment group, firms owning for-profit colleges, relative to the control group following the announcement.

The first three columns of Appendix C Table 2 show results for the initial announcement of GE rules. The first column presents difference-in-differences estimates using post and treatment dummies, the second column adds date fixed effects, while the third column includes both sets of fixed effects. Consistent with the graphical evidence, we see a sharp drop in CAR, and the effect is statistically significant at the .05 level or higher in all specifications. Columns (4) through (6) repeats the analysis for the announcement of the new less restrictive GE rules. The estimates regarding the GE rules being softened are also consistent with the graphical results.

In sum, this analysis provides additional evidence that a major aspect of for-profit market value is rent-seeking capture of government aid, which is unambiguously not in students' or taxpayers' interests. We focus here on publicly traded for-profits, which likely have higher-powered incentives than independent, privately held for-profit schools. Also, the largest of these public firms were once private equity owned. Our result does not in itself imply that private equity buyouts do not

\footnotetext{
${ }^{19}$ See the announcement for more information.
} 
improve education quality. However, in combination with the other evidence in Section 5 (loan limit increase and CDR bunching), it indicates that superior rent-seeking federal aid capture is an important channel through which high-powered incentives translate to higher profits.

Online Appendix 
Table C.1: Major Publicly Traded Higher Education Institutions

\begin{tabular}{lccccc}
\hline & $\begin{array}{c}\text { First private } \\
\text { equity } \\
\text { investment/buyout }\end{array}$ & $\begin{array}{c}\text { IPO } \\
\text { date }\end{array}$ & $\begin{array}{c}\text { Private equity } \\
\text { reverse LBO date } \\
\text { public to private) }\end{array}$ & $\begin{array}{c}\text { Second } \\
\text { IPO date }\end{array}$ & $\begin{array}{c}\text { Share of for-profit } \\
\text { enrollment in 2010 }\end{array}$ \\
EDMC & 1986 & 1996 & 2006 & 2009 & $2.7 \%$ \\
Devry & 1987 & 1991 & & & $2.8 \%$ \\
Corinthian & $1995^{\dagger}$ & 1999 & & $2.1 \%$ \\
Capella & 1995 & 2006 & & $1.6 \%$ \\
Strayer & & 1996 & 2001 & $2.2 \%$ \\
Apollo (U. of Phoenix) & 2004 & 2008 & 2017 & $20.2 \%$ \\
Grand Canyon & 2007 & 2017 & & & $1.4 \%$ \\
Laureate & & & & $1.8 \%$ \\
\hline
\end{tabular}

Note: This table lists the largest for-profit higher education institutions ever publicly traded. ${ }^{\dagger}$ PE-financed acquisition of 15 campuses. 
Table C.2: Gainful Employment Event Studies

\section{Panel 1}

Event:

GE Rules Announced

GE Rules Held

Dependent Variable: Cumulative Abnormal Returns

\begin{tabular}{|c|c|c|c|c|c|c|}
\hline & (1) & (2) & (3) & (4) & (5) & (6) \\
\hline FP X Post & $\begin{array}{c}-0.186^{* * * *} \\
(0.0340)\end{array}$ & $\begin{array}{c}-0.186^{* * *} \\
(0.0344)\end{array}$ & $\begin{array}{c}-0.186^{* * *} \\
(0.0348)\end{array}$ & $\begin{array}{c}0.135 * * * \\
(0.0245)\end{array}$ & $\begin{array}{c}0.135^{* * *} \\
(0.0248)\end{array}$ & $\begin{array}{c}0.135^{* * *} \\
(0.0251)\end{array}$ \\
\hline FP & $\begin{array}{c}-0.0321 * * \\
(0.0146)\end{array}$ & $\begin{array}{c}-0.0321 * * \\
(0.0148)\end{array}$ & & $\begin{array}{c}0.0264 \\
(0.0198)\end{array}$ & $\begin{array}{c}0.0264 \\
(0.0200)\end{array}$ & \\
\hline Post & $\begin{array}{l}0.00455 \\
(0.0181)\end{array}$ & & & $\begin{array}{l}-0.0192 \\
(0.0134)\end{array}$ & & \\
\hline Firm Fixed Effects & No & No & Yes & No & No & Yes \\
\hline Date Fixed Effects & No & Yes & Yes & No & Yes & Yes \\
\hline Observations & 1845 & 1845 & 1845 & 2050 & 2050 & 2050 \\
\hline
\end{tabular}

Note: ${ }^{*}$ Average Cumulative Abnormal Returns for the stocks are calculated around 60-day event windows, $C A R[0, n]=\sum_{t=0}^{n} A R_{i t}$. Standard errors are clustered at the firm level. Coefficients marked with $*, * *, * * *$, denote $\mathrm{p}$ $<.1, \mathrm{p}<.05, \mathrm{p}<.01$, respectively. 
Figure C.1: Density of Cohort Default Rates by Institution Type

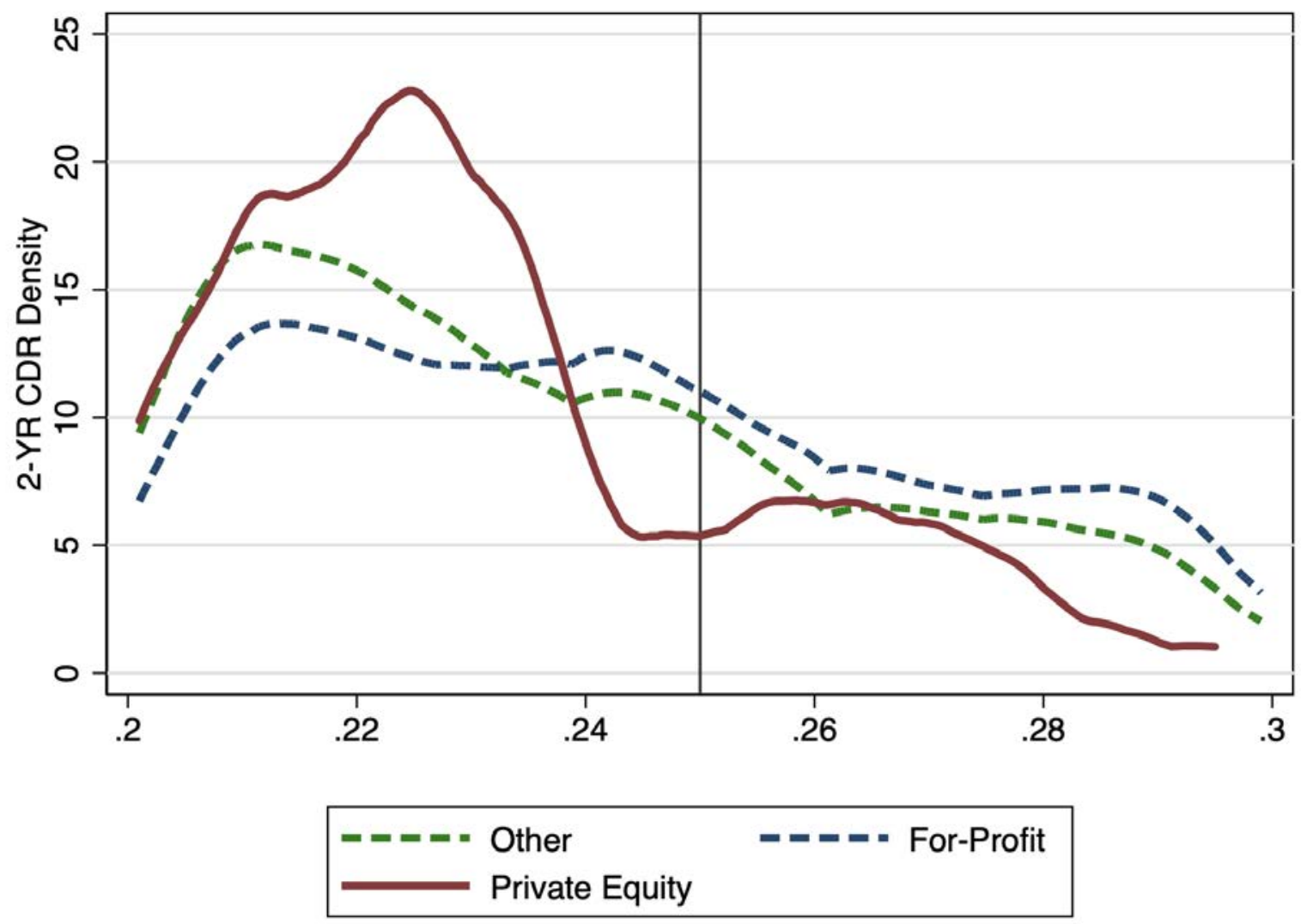

Note: This figure shows the density of two-year cohort default rates, broken down by institution type. 
Figure C.2: Gainful Employment Rules and Cumulative Abnormal Returns
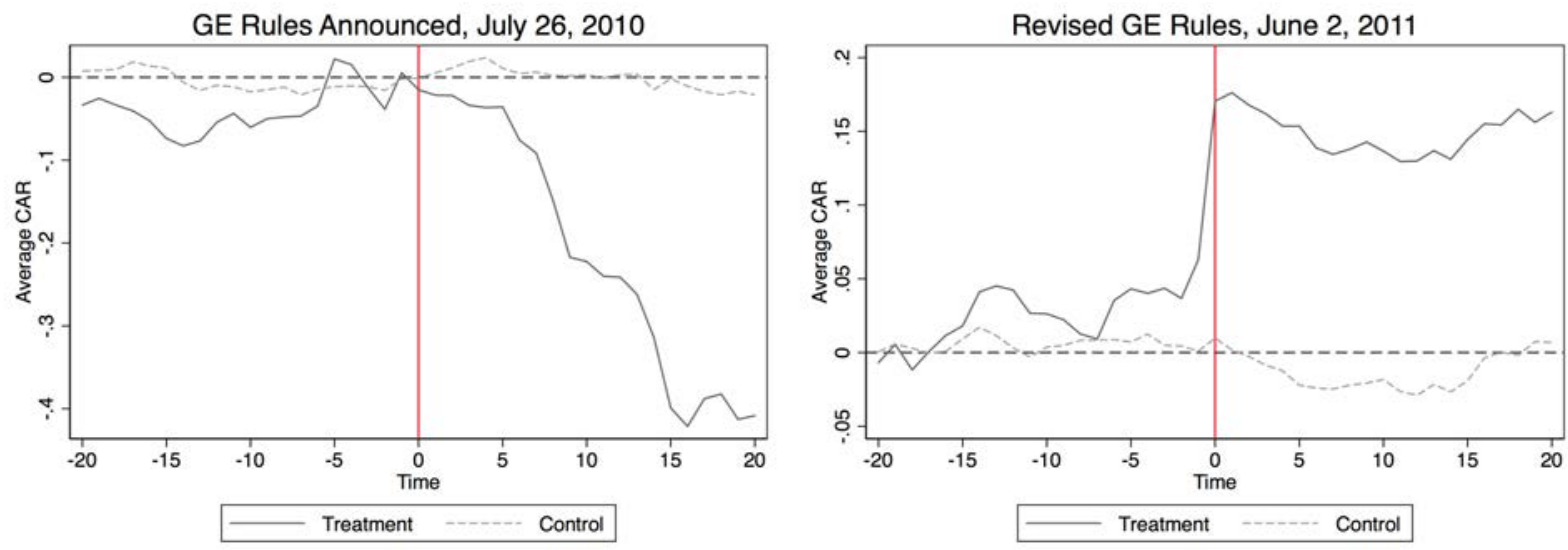

Note: The figure above shows cumulative abnormal returns for treatment and control schools. Average Cumulative Abnormal Returns for the stocks are calculated around 60-day event windows. 


\section{Appendix D: Community Colleges as Source of Additional Enrollment}

We find a large increase in the number of full-time equivalent enrolled students after a buyout. Given the negative effects on student success measures, buyouts are unlikely to make existing student types (i.e., that would have enrolled before the buyout) weakly better off. However, whether additional students - regardless of their preparedness - are better or worse off as a result of the buyout depends on their outside option. At one extreme, additional students may be drawn from a population that would not attend college otherwise. These students may benefit relative to receiving no higher education at all. At the other extreme, private equity-owned schools may draw students away from institutions with higher value-added.

A rich education economics literature finds strong evidence that (a) community colleges are an available substitute to for-profits, and (b) the returns to for-profit education are zero or negative relative to community college education. ${ }^{20}$ We examine evidence for substitution at the commuting zone $(\mathrm{CZ})$ level, which roughly corresponds to a local labor market. We regress the change in all community college enrollment ( $\Delta^{96-16}$ Enrollment) within a $\mathrm{CZ}$ on the change in private equity ( $\Delta^{96-16} \mathrm{PE}$ Enrollment) in that $\mathrm{CZ} .{ }^{21}$ The results are in Appendix D Table 1. If there is no substitution, we expect a coefficient of zero. Conversely, if there is full substitution, we expect a coefficient of -1 . In column 1 , the point estimate is -.67 . The second row shows the results from an F-test that the coefficient is equal to -1 ; it reveals that we cannot reject full substitution away from community colleges. The second column repeats the analysis using full-time enrollment and finds similar results. Corresponding graphical evidence is in Appendix D Figure 1 Panel A. We do not expect substitution from high quality institutions to private equity-owned schools, so we use them in a placebo test. We define high quality institutions as those institutions where more than 50 percent of students graduate within 150 percent of the usual time. There is no effect for higher quality institutions (Appendix D Table 1 columns 3 and 4 and

\footnotetext{
${ }^{20}$ See Jacobson et al. 2005, Jepsen et al. 2014, Liu and Belfield (2014), Cellini and Chaudhary (2014), Darolia et al. (2015), Deming et al. (2016), Cellini and Turner (2016), Armona et al. (2017), and Cellini, Darolia, and Turner (2017). These papers are summarized in Appendix A Section 2.

${ }^{21}$ There were 709 commuting zones in the United States in 2000 . We have a lower number in our sample, as some commuting zones do not have colleges in the sample.
} 
Appendix D Figure 1 Panel B). Thus, the effects in columns 1 and 2 are not driven by general population or other sources of enrollment growth.

Appendix D Figure 2 takes an event study approach within CZs. It shows increasing community college enrollment over time before the entry of a private equity-owned school, and a flat line afterward. Private equity-owned schools appear to siphon enrollment away from community colleges, likely because of superior marketing. ${ }^{22}$ Consistent with this strategy, the targeting analysis in Section 3.3 found that private equity firms tend to acquire schools in commuting zones with a higher number of community colleges. One possibility is that private equity schools draw the worst students away from local community colleges. If this is the case, we would expect to see an improvement in education outcomes at community colleges after private equity entry. To explore this possibility, we examine graduation rates at community colleges in commuting zones following a private equity buyout. We find no significant effect on graduation rates. In sum, additional students enrolled as a result of expansion after buyouts seem to be drawn away from attending community colleges. Together with much higher tuition and lower success measures, this suggests that additional students are unlikely to be made better off by the buyout.

\footnotetext{
${ }^{22}$ Results are available upon request.
} 
Table D.1: Relationship Between Entry and Community College Enrollment

Community Colleges
$\Delta^{96-16} \quad \Delta^{96-16}$

Enrollment

$\Delta^{96-16}$ PE Enrollment

$\Delta^{96-16}$ PE FTE

$-0.67 * *$

FTE

$-1.121^{* *}$

(0.49)

.27

451

Observations

$R^{2}$

High Quality Schools

$\Delta^{96-16} \quad \Delta^{96-16}$

Enrollment FTE

1.09

(0.90)

0.9

$\begin{array}{ll}.0036 & .002\end{array}$

$301 \quad 301$

$\begin{array}{ll}.10 & .09\end{array}$

Note: This table shows the relationship between changes in private equity-owned and community college enrollment at the commuting zone level between 1996 and 2016. Columns 1 and 3 include all enrollment, while columns 2 and 4 include only full-time enrollment. Columns 3 and 4 are placebo tests, which replace community college enrollment with enrollment at institutions that graduate more than half of their students with $150 \%$ of the normal time ("high quality schools"). We also show the p-value from an F-test that the coefficient equals -1, which is consistent with full substitution. Community colleges are defined as public institutions granting two year or lower degrees. Huber-White robust standard errors are presented in parentheses. Coefficients marked with $*, * *, * * *$, denote $\mathrm{p}<.1, \mathrm{p}<.05, \mathrm{p}<$ .01 , respectively. 
Figure D.1: Commuting Zone Enrollment by School Type

Panel A: Commuting Zone Enrollment at Private Equity-Owned and Community Colleges
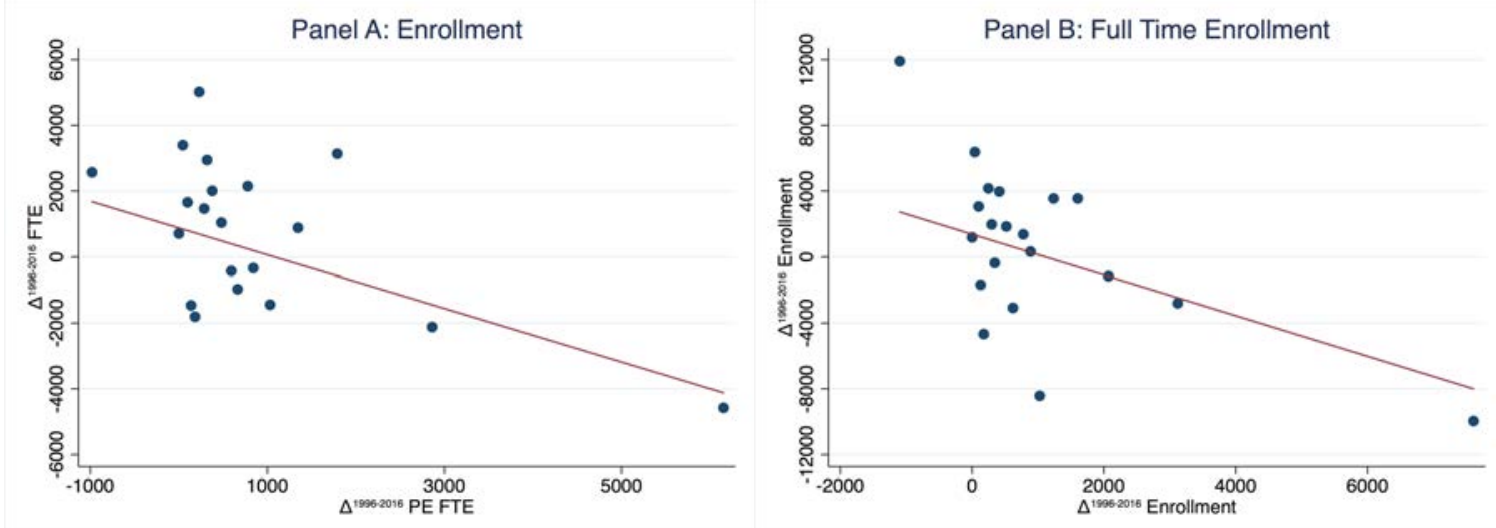

Panel B: Commuting Zone Enrollment at Private Equity-Owned and High Quality Colleges
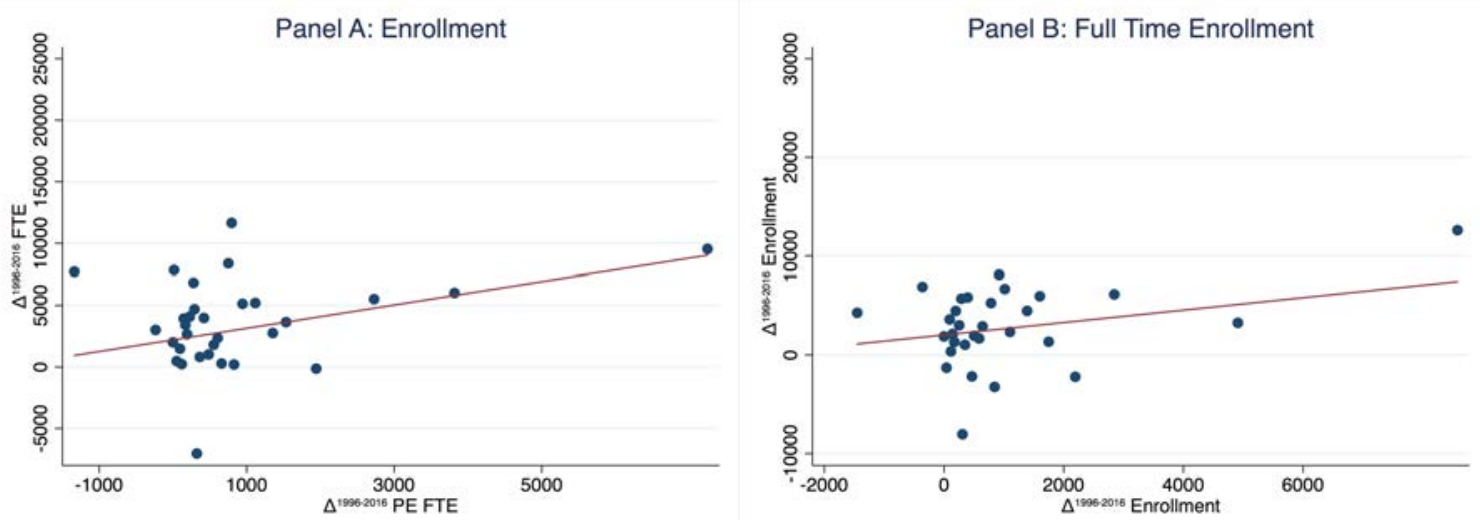

Note: The graphs in Panel A collapse the mean change in community college enrollment and full-time enrollment within a commuting zone into twenty bins ranked by the mean change in private equity-owned school enrollment. The figure on the left (right) shows the cross sectional relationship between the change in enrollment (full-time enrollment) at community colleges and private equity owned for-profits between 1996 and 2016. Community colleges are defined as public institutions granting two year or lower degrees. The graphs in Panel B are a placebo test; they replicate Panel A, but use high quality colleges ( $>50 \%$ of students graduate in normal time) rather than community colleges. 
Figure D.2: Private Equity-Owned School Entry and Community College Enrollment

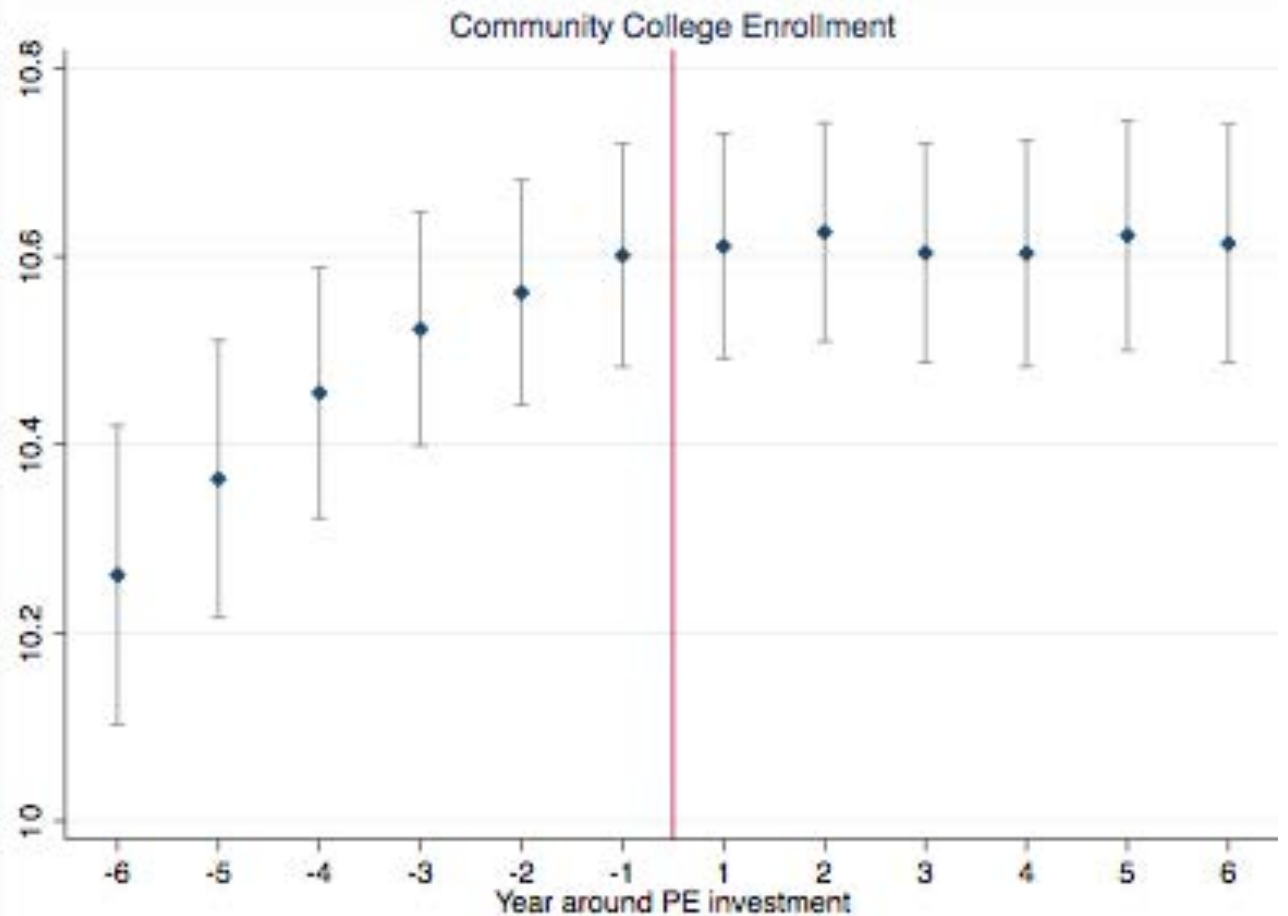

Note: This figure shows log enrollment in community colleges before and after the entry of a private equity backed for-profit college, within a commuting zone. Community colleges are defined as public institutions that grant two year or lower degrees. 


\section{Appendix E: Course Catalogs}

All Title IV colleges are required to disclose their ownership history through course catalogs, which are collected by the Department of Education. We researched ownership history of schools in part through these course catalogs. An example is given below, of the University of Phoenix, which in 2016 was the largest for-profit college in the United States. The University of Phoenix is a subsidiary of Apollo Education Group, which is wholly owned by Apollo Global Management and the Vistria Group, a Chicago-based private equity fund. Thus the 2018 course catalog notes on p.1 that: "University of Phoenix, Inc. is a wholly-owned subsidiary of Apollo Education Group, Inc. ("the Parent"). The Parent's stock is wholly-owned by AP VIII Queso Holdings, L.P., which is owned by Apollo Global Management, LLC and The Vistria Group, LLC." 
Figure E.1: Sample Course Catalog

University of Phoenix, 2018-2019

UNIVERSITY OF PHOENIX

\section{UNIVERSITY OF PHOENIX}

\section{Beginnings -- A Brief History}

In 1976, the leading edge of the Baby Boom generation was just turning 30 . That same year saw the introduction of the first personal computer, the Apple I -- an event that signaled the birth of a new economic system in which intellectual capital would eventually supplant industrial might as the dominant economic force. These milestones marked the beginning of a sea of change in higher education, though many (perhaps even most) within that system did not recognize it at the time.

Considered together, these phenomena suggested that the jobs that would make up the workforce of the future were only just beginning to be created or imagined. In order to fill those jobs, the bulk of the new workforce would require higher-level knowledge and skills than those needed in a manufacturing economy. At the same time, the largest-ever age cohort of the population, adult learners, would be going through the stages of life during which they would be most affected by the coming economic dislocation and would need advanced education to adapt to these changes.

It was in this historical context in 1976 that Dr. John Sperling, a Cambridge-educated economist and professor-turned-entrepreneur, founded University of Phoenix. Sperling anticipated the confluence of technological, economic, and demographic forces that would in a very short time herald the return of ever larger numbers of adult learners to formal higher education.

In the early 1970s, at San Jose State University in San Jose, California, Sperling and several associates conducted field-based research in adult education. The focus of the research was to explore teaching/learning systems for the delivery of educational programs and services to adult learners who wished to complete or further their education in ways that complemented both their experience and current professional responsibilities. At that time colleges and universities were organized primarily around serving the needs of the 18-22 year-old undergraduate student. That is not all that surprising, given that the large majority of those enrolled were residential students of traditional college age, just out of high school. According to Sperling adult learners were invisible on the traditional campus and were treated as second-class citizens.

Other than holding classes at night (and many universities did not even do this), no efforts were made to accommodate their needs. No university offices or bookstores were open at night. Students had to leave work during the day to enroll, register for classes, buy books or consult with their instructors and advisors. Classes were held two or three nights per week and parking was at the periphery of a large campus. The consequence, according to Dr. Sperling was that most adult learners were unable to finish a four-year program in less than eight years, or a two-year program in less than four years (Tucker, 1996, p. 5).

Sperling's research convinced him not only that these underserved learners were interested in furthering their educational goals, but also that this group differed from their more traditional counterparts in significant ways. He saw a growing need for institutions that were sensitive to and designed around the learning characteristics and life situations of a different kind of learner population. He suggested ways for institutions to pioneer new approaches to curricular and program design, teaching methods, and student services. These beliefs eventually resulted in the creation of University of Phoenix, and they continue to this day to inspire the University's mission, purpose, and strategies. As an institution, University of
Phoenix is unique in its single-minded commitment to the educational needs of non-traditional students, who in fact today make up the majority (73 percent) of all college enrollees. This focus informs the University's teaching and learning model approach to designing and providing student services, and academic and administrative structure. It also guides the institution as it plans and prepares to meet the needs of the next generation of learners. Over the last three and a half decades, the University of Phoenix has been cause-driven working to build an institution with the agility to address directly the shifting economic and academic challenges that many students face. Dr. Sperling's predictions concerning the innovations higher education would be required to make have come to pass. Today roughly 45 percent of all college students work at least part-time and approximately one quarter of all students have dependent children. The educational tenets set forth by Dr. Sperling in 1976 now apply to the majority of college students in the United States.

\section{Official School Colors}

University of Phoenix Official School Colors are University of Phoenix Red and University of Phoenix Platinum.

These are custom colors and proprietary to the University. Ownership Intormation

University of Phoenix, Inc. is a wholly-owned subsidiary of Apollo Education Group, Inc. ("the Parent"). The Parent's stock is whollyowned by AP VIII Queso Holdings, L.P., which is owned by Apollo Global Management, LLC and The Vistria Group, LLC. The University's central administration is located in Phoenix, Arizona. Our MIssion Statement

University of Phoenix provides access to higher education opportunities that enable students to develop knowledge and skills necessary to achieve their professional goals, improve the performance of their organizations, and provide leadership and service to their communities.

\section{Our Purpose}

- To facilitate cognitive and affective student learning-knowledge, skills, and values- and to promote use of that knowledge in the student's workplace.

- To develop competence in communication, critical thinking, collaboration, and information utilization, together with a commitment to lifelong learning for enhancement of students' opportunities for career success.

- To provide instruction that bridges the gap between theory and practice through faculty members who bring to their classroom not only advanced academic preparation, but also the skills that come from the current practice of their professions.

- To provide General Education and foundational instruction and services that prepare students to engage in a variety of university curricula.

- To use technology to create effective modes and means of instruction that expand access to learning resources and that enhance collaboration and communication for improved student learning. 


\section{References}

Acemoglu, D., S. Johnson, A. Kermani, J. Kwak, and T. Mitton (2016). The value of connections in turbulent times: Evidence from the United States. Journal of Financial Economics (121), 368-391.

Arcidiacono, P., E. Aucejo, A. Maurel, and T. Ransom (2016). College attrition and the dynamics of information revelation. NBER Working Paper No. 22325.

Armona, L., R. Chakrabarti, and M. F. Lovenheim (2017). How does for-profit college attendance affect student loans, defaults and earnings? NBER Working Paper No. 25042.

Berman, E. P. and A. Stivers (2016). Student loans as a pressure on US higher education. The University under Pressure 46, 129-160.

Bernstein, S. and A. Sheen (2016). The operational consequences of private equity buyouts: Evidence from the restaurant industry. Review of Financial Studies 29(9), 2387-2418.

Bettinger, E. P., B. T. Long, P. Oreopoulos, and L. Sanbonmatsu (2012). The role of application assistance and information in college decisions results from the H\&R Block FAFSA experiment. The Quarterly Journal of Economics 127(3), 1205-1242.

Bloom, N., R. Sadun, and J. Van Reenen (2015). Do private equity owned firms have better management practices? The American Economic Review 105(5), 442-446.

Campbell, J. Y., A. W.-C. Lo, and A. C. MacKinlay (1997). The Econometrics of Financial Markets. Princeton University Press.

Cellini, S., R. Darolia, and L. Turner (2017). Where do students go when for-profit colleges lose federal aid? Working Paper.

Cellini, S. R. (2010). Financial aid and for profit colleges: Does aid encourage entry? Journal of Policy Analysis and Management 29(3), 526-552.

Cellini, S. R. and L. Chaudhary (2014). The labor market returns to a for-profit college education. Economics of Education Review 43, 125-140.

Cellini, S. R. and C. Goldin (2014). Does federal student aid raise tuition? New evidence on for-profit colleges. American Economic Journal: Economic Policy 6(4), 174-206.

Cellini, S. R. and N. Turner (2016). Gainfully employed? Assessing the employment and earnings of for-profit college students using administrative data. NBER Working Paper No. 22287.

Chung, A. S. (2012). Choice of for-profit college. Economics of Education Review 31(6), 1084-1101.

Darolia, R., C. Koedel, P. Martorell, K. Wilson, and F. Perez-Arce (2015). Do employers prefer workers who attend for-profit colleges? Evidence from a field experiment. Journal of Policy Analysis and Management 34(4), 881-903.

Davis, S. J., J. Haltiwanger, K. Handley, R. Jarmin, J. Lerner, and J. Miranda (2014). Private equity, jobs, and productivity. The American Economic Review 104(12), 3956-3990.

Deming, D. J., C. Goldin, and L. F. Katz (2012, dec). The for-profit postsecondary school sector: Nimble critters or agile predators? Journal of Economic Perspectives 26(1), 139-64.

Deming, D. J., N. Yuchtman, A. Abulafi, C. Goldin, and L. F. Katz (2016). The value of postsecondary 
credentials in the labor market: An experimental study. The American Economic Review 106(3), 778806.

Eaton, C., J. Habinek, A. Goldstein, C. Dioun, D. G. Santibáñez Godoy, and R. Osley-Thomas (2016). The financialization of US higher education. Socio-Economic Review 14(3), 507-535.

Hentschke, G. C. (2010). Innovations in business models and organizational cultures: The for-profit sector. USC Rossier School of Education (June).

Jacobson, L., R. LaLonde, and D. G. Sullivan (2005). Estimating the returns to community college schooling for displaced workers. Journal of Econometrics 125(1), 271-304.

Jepsen, C., K. Troske, and P. Coomes (2014). The labor-market returns to community college degrees, diplomas, and certificates. Journal of Labor Economics 32(1), 95-121.

Kelchen, R. (2017, January). How much do for-profit colleges rely on federal funds? Brookings Institution Chalkboard.

Lang, K. and R. Weinstein (2013). The wage effects of not-for-profit and for-profit certifications: Better data, somewhat different results. Labour Economics 24, 230-243.

Liu, Y. T. and C. Belfield (2014). The labor market returns to for-profit higher education: Evidence for transfer students. A CAPSEE Working Paper. Center for Analysis of Postsecondary Education and Employment.

Looney, A. and C. Yannelis. The consequences of student loan credit expansions: Evidence from three decades of default cycles.

Looney, A. and C. Yannelis (2015). A crisis in student loans? How changes in the characteristics of borrowers and in the institutions they attended contributed to rising loan defaults. Brookings Papers on Economic Activity, 1-89.

Metrick, A. and A. Yasuda (2010). The economics of private equity funds. The Review of Financial Studies 23(6), 2303-2341.

Metrick, A. and A. Yasuda (2011). Venture capital and other private equity: a survey. European Financial Management 17(4), 619-654.

Schilbach, F., H. Schofield, and S. Mullainathan (2016). The psychological lives of the poor. The American Economic Review 106(5), 435-440.

Senate (2012). For profit higher education: The failure to safeguard the federal investment and ensure student success.

Shireman, R. (2017). Learn now, pay later: A history of income-contingent student loans in the United States. The ANNALS of the American Academy of Political and Social Science 671(1), 184-201.

Wilson, R. (1987). Two banking industry representatives play key lobbying role on student loans. Chronicle of Higher Education, 26.

Wiswall, M. and B. Zafar (2014). Determinants of college major choice: Identification using an information experiment. Review of Economic Studies 82(2), 791-824. 